\title{
Flora da Bahia: Malpighiaceae 2 - Heteropterys
}

\author{
Cleiton Pessoa ${ }^{1,2 *}$, Jorge Antonio Silva Costa ${ }^{3, \mathrm{a}}$ \& André Márcio Amorim ${ }^{1,2,4, \mathrm{~b}}$ \\ ${ }^{1}$ Departamento de Ciências Biológicas, Universidade Estadual de Feira de Santana, Bahia, Brasil. \\ ${ }^{2}$ Centro de Pesquisas do Cacau, Itabuna, Bahia, Brasil. \\ ${ }^{3}$ Instituto Sosígenes Costa de Humanidades, Artes e Ciências, Universidade Federal do Sul da Bahia, Porto \\ Seguro, Bahia, Brasil. \\ ${ }^{4}$ Departamento de Ciências Biológicas, Universidade Estadual de Santa Cruz, Ilhéus, Bahia, Brasil.
}

\begin{abstract}
Resumo - É apresentado o levantamento florístico do gênero Heteropterys para o estado da Bahia, Brasil. Foram reconhecidas 43 espécies de Heteropterys no estado. Dentre elas, H. cochleosperma, H. macradena, H. syringifolia e H. trigoniifolia são registradas pela primeira vez no Estado. Onze espécies são consideradas endêmicas e seis constam no Livro Vermelho da Flora do Brasil. O tratamento inclui uma chave de identificação, descrições, comentários, além de ilustrações e mapas de distribuição geográfica das espécies na Bahia.

Palavras-chave adicionais: Brasil, florística, Malpighiales, nordeste brasileiro, taxonomia.
\end{abstract}

\begin{abstract}
Flora of Bahia: Malpighiaceae 2 - Heteropterys) - A floristic survey of the genus Heteropterys from Bahia state, Brazil, is presented. A total of 43 species of Heteropterys were recognized, among which H. cochleosperma, H. macradena, H. syringifolia and H. trigoniifolia represent new records for the state. Eleven species are considered endemics to this state and six are listed in the Red Book of Flora of Brazil. The treatment includes an identification key, descriptions and comments, as well as illustrations and distribution maps of the species in Bahia.
\end{abstract}

Additional key words: Brazil, Brazilian Northeast, floristics, Malpighiales, taxonomy.

Malpighiaceae apresenta 77 gêneros e ca. 1.300 espécies, das quais 90\% são neotropicais (Davis \& Anderson 2010). No Brasil, ocorrem 44 gêneros e aproximadamente 530 espécies (Mamede et al. 2014). Na Bahia, à família é representada por 28 gêneros e 187 espécies, sendo este o estado brasileiro com a maior riqueza do grupo (Mamede et al. 2014). As Malpighiaceae são reconhecidas pela presença de tricomas unicelulares, em forma de T, Y, V ou adpressos, sépalas geralmente com duas glândulas secretoras de óleo (elaióforos) na base da face abaxial, pétalas geralmente unguiculadas, ovário súpero, 3-carpelar, sincárpico, placentação axial, 3 estiletes geralmente livres; estigmas heteromórficos; 1 óvulo por lóculo e frutos geralmente esquizocárpicos, frequentemente alados, ocasionalmente bagas, nozes ou drupas (Anderson 1979, 1981). Uma descrição mais ampla da família para a Flora da Bahia foi apresentada por Carvalho et al. (2010).

\section{Heteropterys Kunth}

Liana, arbusto ou arvoreta; ramos cilíndricos a subcilíndricos, às vezes triangulares, quadrangulares, octogonais, aplanados ou sulcados, superfície lisa, estriada ou fissurada, glabros ou pilosos, ferrugíneos, castanho-claros ou raro vináceos; lenticelas ausentes, esparsas ou aglomeradas, às vezes encobertas pelos tricomas; estípulas epipeciolares ou interpeciolares, diminutas, distintas entre si, triangulares, inseridas na

\footnotetext{
*Autor para correspondência: cleitonspessoa@hotmail.com;

a costa.bio@gmail.com; ${ }^{\mathrm{b}}$ amorim.uesc@gmail.com

Editor responsável: Alessandro Rapini

Submetido: 30 jul. 2014; aceito: 17 set. 2014

Publicação eletrônica: $30 \mathrm{dez}$. 2014; versão final: 20 jan. 2015
}

base do pecíolo ou no ramo ao lado do pecíolo, persistentes ou caducas. Folhas simples, opostas (alternas em $H$. alternifolia e $H$. conformis), apressas (H. byrsonimifolia, H. escalloniifolia e $H$. sincorensis) ou não aos ramos; pecíolo encoberto ou não pela base da lâmina; lâmina com margem inteira a sinuada, com emergências ou não; indumento de coloração ferrugínea ou metálica; glândulas encobertas ou não pelos tricomas quando presente; nervuras e retículo evidentes a inconspícuos. Inflorescências em panículas, laxas ou congestas, terminais, axilares ou nascidas em ramos basais áfilos, pêndulas ou eretas, seríceas, tomentosas ou glabrescentes, as últimas unidades em umbelas ou corimbos, ferrugíneas ou castanho-claras; pedúnculo maior, menor ou do tamanho do pedicelo, ou ausente; brácteas arredondadas, ovais ou triangulares, glandulosas ou não, face adaxial glabra, a abaxial serícea ou tomentosa, escamiformes ou foliáceas; bractéolas inseridas no ápice do pedúnculo ou abaixo, glandulosas ou não; pedicelo seríceo ou tomentoso, uniformemente delgado ou alargando-se atenuada ou abruptamente em direção ao ápice. Sépalas 5 , encobrindo as pétalas no botão floral (subgênero Parabanisteria) ou não, ápice obtuso, triangular ou arredondado, revoluto ou plano após antese, face adaxial glabra, abaxial tomentosa, velutina ou serícea, laterais biglandulosas e anterior eglandulosa ou todas eglandulosas ou todas glandulosas $(H$. bicolor com duas glândulas decorrentes ao pedicelo). Pétalas 5, glabras, unguiculadas, membranáceas ou crassas (quando crassas, podem apresentar carena ou não). Estames 10, iguais ou desiguais, conados na base; filetes glabros ou pilosos na base; conectivos uniformemente escuros ou 
escuros na base e claros no ápice ou uniformemente claros. Ovário tomentoso, velutino ou seríceo; 3estiletes canaliculados ou aplanados, de mesmo tamanho, menores ou excedendo o androceu. Samarídeos com ala dorsal espessada na margem inferior, com disposição horizontal, oblíqua ou perpendicular; núcleo seminífero oval ou arredondado; carpóforo ausente; alas ou álulas laterais reduzidas ou ausentes.

Heteropterys é o maior gênero de Malpighiaceae, com cerca de 150 espécies, apresentando uma distribuição predominantemente neotropical (Anderson
2013), ocorrendo em diferentes hábitats (Amorim 2003a, 2014; Anderson et al. 2006; Anderson 2013). No Brasil, ocorrem 97 espécies e o estado da Bahia apresenta a maior representatividade do gênero (Amorim 2014). Das 43 espécies encontradas na Bahia, 11 são endêmicas e seis estão no Livro Vermelho da Flora do Brasil (Amorim et al. 2013; Amorim 2014). A Floresta Atlântica se destaca com a maior riqueza de espécies (18), seguida pela Caatinga (9) e o Cerrado (2), mas existem espécies que ocorrem em mais de um domínio, como Caatinga/Floresta Atlântica (5 espécies), Caatinga/Cerrado (8) ou nos três domínios (1).

\section{Chave para as espécies}

1. Arbustos ou arvoretas, raro lianas; lâmina foliar frequentemente coriácea; sépalas com ápice revoluto (Figura 23A).

2. Face abaxial da lâmina foliar serícea a glabrescente.

3. Lâmina foliar oval (Figura 18A), base obtusa a arredondada (Figura 18B) ou subcordada; estilete anterior de mesmo tamanho que os posteriores; estigma do estilete anterior voltado para o centro da flor e dos posteriores voltados para as pétalas latero-posteriores (Figura 18C)

8. H. byrsonimifolia

3'. Lâmina foliar oblanceolada a elíptica (Figura 20A), base cuneada, raro obtusa; estilete anterior maior que os posteriores; todos os estigmas voltados para a pétala posterior (Figura 20C)

2'. Face abaxial da lâmina foliar glabra.

19. H. escalloniifolia

4. Lâmina foliar com margem ondulada.

5. Lâmina oval ou elíptica (Figura 20M); conectivos uniformemente escuros (vermelhos)

25. $\mathrm{H}$ macradena

5'. Lâmina oblonga (Figura 20H) a oboval, raro elíptica a oval; conectivos escuros (vermelhos) na região proximal e claros (amarelos) na região distal

4'. Lâmina foliar com margem revoluta.

6. Pecíolo tomentoso a glabrescente (Figura 18G); base da lâmina foliar geralmente cordada (Figura $18 \mathrm{~F})$; anteras pilosas 16. $H$. coriacea

6'. Pecíolo seríceo a glabrescente; base da lâmina foliar geralmente cuneada; anteras glabras.

7. Pecíolo seríceo a glabrescente; lâmina foliar elíptica a oval (Figura 18K); estiletes retos, posteriores não arqueados na base

18. H. eglandulosa

7'. Pecíolo glabrescente; lâmina foliar lanceolada a oval-lanceolada; estiletes curvilíneos, os posteriores arqueados na base ............................................................ 28. H. nervosa

1'. Lianas ou formas escandentes, raro arbustos eretos; lâmina foliar membranácea a cartácea (raro coriácea); sépalas com ápice plano (Figura 23B).

8. Pedicelos sésseis (Figura 23E).

9. Sépalas ferrugíneas (tanto na exsicata, quanto no material vivo); pétalas crassas, carenadas ou não, frequentemente patentes.

10. Folhas com nervuras e retículos formando uma superfície fortemente bulada

10'. Folhas com nervuras evidentes e retículos inconspícuos, não formando uma superfície bulada.

11. Lâmina foliar tomentosa a glabrescente na face adaxial.

12. Estiletes com ápice dorsalmente obtuso ou obtuso-apiculado; todos os estigmas voltados para o centro da flor.

23. H. jardimii

12'. Estiletes com ápice dorsalmente arredondado; todos os estigmas voltados para pétala posterior

15. $\boldsymbol{H}$. cordifolia

11'. Lâmina foliar glabrescente ou glabra na face adaxial (serícea apenas em $H$. catingarum).

13. Últimas unidades das inflorescências em corimbos 4-20-floros

31. H. oberdanii

13'. Últimas unidades das inflorescências em umbelas 4-6-floras.

14. Sépalas 1,4-1,8 mm compr.; inflorescências pêndulas; estiletes 2,9-3,3 mm compr.

30. H. nordestina

14'. Sépalas 1,8-2,5 mm compr.; inflorescências eretas; estiletes 4-4,5 mm compr.

21. H. imperata

9'. Sépalas castanho-claras (tanto na exsicata, quanto no material vivo); pétalas membranáceas, carena ausente, geralmente reflexas a sub-reflexas.

15. Lâmina foliar membranácea

10. H. catingarum 
15'. Lâmina foliar cartácea a coriácea.

16. Estilete anterior reto, os posteriores curvilíneos e arqueados na base, ápice dorsalmente obtuso; todos os estigmas voltados para o centro da flor $14 \mathrm{H}$. conformis

16'. Estilete anterior inclinado em direção à sépala anterior e os posteriores em direção às pétalas latero-posteriores, ápice truncado; todos os estigmas voltados para cima ..... 37. H. sanctorum

8'. Pedicelos pedunculados (Figura 23F).

17. Pétalas alvas a róseas, crassas, com carenas proeminentes (Figura 24A, B).

18. Pecíolo $\leq 1,4 \mathrm{~mm}$ compr; base da lâmina foliar cordada (Figura 21J); samarídeos com álulas laterais conspícuas no núcleo seminífero (Figura $21 \mathrm{~N}, \mathrm{O}$ )

38. H. sessilifolia

18'. Pecíolo 1,5-11,5 mm compr.; base da lâmina foliar cuneada, obtusa, arredondada ou subcordada (raro cordada em $H$. pteropetala); samarídeos com núcleo seminífero liso, rugoso ou com nervuras e/ou cristas laterais conspícuas ou inconspícuas.

19. Bractéolas lineares, em geral decíduas na pós-antese

9. H. caducibracteata

19'. Bractéolas elípticas a orbiculares, geralmente persistentes.

20. Arbustos.

21. Lâmina foliar geralmente orbicular; samarídeos com nervuras laterais conspícuas no núcleo seminífero

33. H. pteropetala

21'. Lâmina foliar oval a subcordada; samarídeos com várias cristas laterais conspícuas no núcleo seminífero (Figura 21D, E) . 35. H. rubiginosa

20'. Lianas, raro arbustos.

22. Face abaxial da lâmina foliar com 2 glândulas conspícuas e estipitadas; estiletes posteriores arqueados na base, inclinados em direção às pétalas latero-posteriores (Figura 21F)

36. H. rufula

22'. Face abaxial da lâmina foliar eglandulosa ou com 2-4 glândulas impressas, às vezes inconspícuas, próximo à base, no terço-médio ou intramarginais; estiletes posteriores geralmente retos.

23. Lâmina foliar com indumento velutino na face abaxial; pétalas laterais com margens inteiras e posterior erosa

32. H. perplexa

23'. Lâmina foliar com indumento tomentoso a glabrescente na face abaxial; todas as pétalas com margens erosas

42. H. trigoniifolia

17'. Pétalas amarelas (exceto em H. bicolor), membranáceas a crassas, carenas ausentes (Figura 24C, D).

24. Estames geralmente com filetes pilosos na base (Figuras 17Q e 24G, $\mathrm{H}$ ) (exceto H. bicolor, $\mathrm{H}$. megaptera e H. sincorensis); estiletes geralmente diminutos, com comprimento em geral menor que o ovário.

25. Lâmina foliar com indumento dourado ou metálico-seríceo na face abaxial (Figura 23C, D).

26. Folhas geralmente alternas; lâmina foliar com margem fortemente revoluta

2. H. alternifolia

26'. Folhas opostas; lâmina foliar com margem plana ou levemente revoluta.

27. Lâmina foliar com a face adaxial serícea a glabrescente

29. H. nitida

27'. Lâmina foliar com a face adaxial glabra.

28. Samarídeos com álulas laterais no núcleo seminífero (Figura 17K, L)

13. H. coleoptera

28'. Samarídeos com núcleo seminífero liso, rugoso ou com nervuras e/ou cristas laterais conspícuas ou inconspícuas.

29. Pecíolo eglanduloso

3. H. andersonii

29'. Pecíolo glanduloso.

30. Lianas; pecíolo com 2-4 glândulas distribuídas entre o terço-médio e o ápice (Figura 17M, N)

26. H. macrostachya

30'. Arbustos; pecíolo com 2 glândulas na base ou no ápice.

31. Lâmina foliar com ápice obcordado-mucronado; últimas unidades da inflorescência em umbelas 4-floras; estiletes retos, paralelos entre si (Figura 17D)

4. H. arenaria

31'. Lâmina foliar com ápice geralmente obtuso a retuso; últimas unidades da inflorescência em corimbos 10-floros; estiletes curvilíneos, divergentes distalmente ....... 11. H. chrysophylla

25'. Lâmina foliar com outros tipos de indumento ou glabrescentes na face abaxial.

32. Pecíolo com duas glândulas estípitadas na base; sépalas latero-posteriores, cada uma, com uma glândula decorrente ao pedicelo; pétalas alvas, a posterior com máculas vináceas

5. H. bicolor 
32'. Pecíolo eglanduloso; sépalas latero-posteriores sem glândulas decorrentes ao pedicelo; pétalas amarelas, a posterior sem máculas ou todas laranja-avermelhadas, com faixa avermelhada na face abaxial (em H. sincorensis).

33. Folhas não apressas aos ramos; lâmina foliar oval a lanceolada; anteras pilosas .....

27. H. megaptera

33'. Folhas apressas aos ramos, lâmina foliar geralmente suborbicular; anteras glabras

39. H. sincorensis

24'. Estames geralmente com filetes glabros na base (Figura 24E, F); estiletes bem desenvolvidos, de comprimento em geral igual ou maior que o ovário.

34. Pecíolo em geral biglanduloso na base (Figura 23H) (eglanduloso ou raramente biglanduloso em $H$. intermedia); bractéola inserida no ápice do pedúnculo.

35. Lâmina foliar com a face abaxial tomentosa; pétala posterior com margem glandulosa; anteras pilosas

6. H. brunnea

35'. Lâmina foliar com a face abaxial serícea a glabrescente (glabra em $H$. wiedeana); pétala posterior com margem eglandulosa; anteras glabras.

36. Estiletes com ápice dorsalmente arredondado ou obtuso

22. H. intermedia

36'. Estiletes com o ápice dorsalmente apiculado e/ou apiculado-uncinado.

37. Estiletes com base glabra, todos com o estigma voltado para a pétala posterior .

43. H. wiedeana

37'. Estiletes com base pilosa, o anterior com estigma voltado para o centro da flor, os posteriores voltados para as pétalas latero-posteriores

24. H. leschenaultiana

34'. Pecíolo geralmente eglanduloso ou biglanduloso no terço-médio ou no ápice (Figura 23G); bractéola inserida abaixo do ápice do pedúnculo (Figura 23F).

38. Anteras pilosas.

39. Pecíolo biglanduloso no terço-médio ou ápice; sépalas 2,7-3,7 $\mathrm{mm}$ compr.; todas as pétalas 2,8-4,1 × 2,3-3,1 mm; estiletes 2,3-2,5 mm compr. 41 . H. trichanthera

39'. Pecíolo eglanduloso; sépalas 1,5-2 mm compr; todas as pétalas $1,4-2,8 \times 1,2-2,4$ $\mathrm{mm}$; estiletes $1,6-2,1 \mathrm{~mm}$ compr.

38'. Anteras glabras. 1. H. aliciae

40. Lâmina foliar eglandulosa na face abaxial; samarídeos com nervuras laterais inconspícuas no núcleo seminífero (Figura 19F)

40'. Lâmina foliar com 2-4 glândulas na face abaxial; samarídeos com núcleo seminífero liso ou com nervuras laterais conspícuas (Figuras 190 e 22E, F).

41. Lâmina foliar com 2 glândulas impressas na base (Figura 19L); estiletes pilosos na base

34. H. rhopalifolia

41'. Lâmina foliar com 2-4 glândulas estipitadas próximo à base ou terço-médio; estiletes glabros na base.

42. Pecíolo geralmente seríceo; sépalas latero-posteriores geralmente triglandulosas (Figura 19K); estiletes com ápice de padrão misto (e.g., o anterior com ápice dorsalmente truncado-uncinado e os posteriores com ápice dorsalmente apiculado-uncinado) (Figura 19I, J) ....

17. H. dumetorum

42'. Pecíolo geralmente tomentoso (Figura 22B); sépala anterior eglandulosa e as laterais biglandulosas, ou todas eglandulosas; estiletes com ápice apiculado ou apiculado-uncinado (Figura 22H)

40. H. syringifolia

1. Heteropterys aliciae W.R.Anderson, Contr. Univ. Michigan Herb. 16: 75. 1987.

Figura 1; Anderson (1987: fig. 8).

Liana, 1-2 $\mathrm{m}$ alt. Folhas membranáceas a papiráceas; pecíolo $2-5 \mathrm{~mm}$ compr., velutino a glabrescente, eglanduloso; lâmina 4-7,2 × 1,7-3,6 cm, elíptica a oval, base arredondada a subcordada, ápice agudo, arredondado a cuspidado, margem plana; face adaxial serícea a glabrescente; a abaxial serícea, com 2 glândulas marginais. Corimbos 4-18-floros; brácteas 0,9-1,6 mm compr.; bractéolas $0,5-1,1 \mathrm{~mm}$ compr., ovais; pedicelos 2,1-4,8 mm compr., pedunculados. Sépalas 1,5-2,0 × 0,9-1,5 mm, ápice plano, seríceoferrugíneas; as laterais biglandulosas e a anterior eglandulosa, ou todas biglandulosas. Pétalas amarelas, membranáceas, margem inteira a eroso-denticulada; as laterais reflexas, limbo 1,9-2,8 × 1,7-2,4 mm; a posterior patente, limbo $1,4-1,9 \times 1,2-1,7 \mathrm{~mm}$. Estames desiguais; filetes glabros, 1,6-2,4 $\mathrm{mm}$ compr.; anteras pilosas, eretas. Ovário seríceo; estiletes 1,6-2,1 mm compr., retos, paralelos entre si, os posteriores arqueados na base e mais curtos que o 
anterior, glabros, ápice dorsalmente apiculado ou truncado; estigmas laterais, voltados para a pétala posterior. Samarídeos seríceos; ala dorsal 22,5-37,2 mm compr.; núcleo seminífero liso.

Distribuição restrita ao Cerrado da Bahia (Anderson 1987; Amorim 2014). G3: em cerrados, a cerca de 530 m s.n.m. Coletada com flores e frutos em março.

Material examinado - Cocos, $14^{\circ} 10^{\prime} 48^{\prime \prime} \mathrm{S}, 44^{\circ} 31^{\prime} 48^{\prime \prime} \mathrm{W}, 17$ mar. 1972 (fl., fr.), W.R. Anderson et al. 37119 (holótipo K foto; isótipos MICH foto, NY foto)

Heteropterys aliciae é caracterizada pelo pecíolo 2 $5 \mathrm{~mm}$ compr., lâmina foliar com duas glândulas marginais impressas próximo à base da face abaxial, inflorescência com últimas unidades em corimbos 4 18 floros e pétalas com margem inteira a erosodenticulada, com a posterior 1,4-1,9 $\mathrm{mm}$ compr. Assemelha-se a $H$. trichanthera pela forma da lâmina foliar, indumento e coloração das sépalas, pilosidade dos filetes, anteras, ovário e samarídeos, além da posição dos estigmas, sendo diferenciada pela posição e presença ou ausência das glândulas no pecíolo, últimas unidades da inflorescência, tamanho das sépalas, pétalas e estiletes. Heteropterys aliciae está posicionada na série Xanthopetalis Nied., juntamente com $H$. bicolor, $H$. cochleosperma, $H$. dumetorum, $H$. rhopalifolia, $H$. syringifolia e $H$. trichanthera, as quais compartilham semelhanças relacionadas ao pecíolo geralmente eglanduloso, lâminas foliares pilosas e pétalas amarelas (exceto $H$. bicolor, que apresenta pétalas alvas) (Amorim 2003a). Segundo Amorim et al. (2013), é uma espécie criticamente em perigo.

2. Heteropterys alternifolia W.R.Anderson, Contr. Univ. Michigan Herb. 19: 368. 1993.

Figura 1; Anderson (1993: fig. 4).

Arbusto ou liana, 4-8 m alt. Folhas cartáceas; pecíolo 3,9-13,1 mm compr., seríceo a glabrescente, terço-médio 2(-4)-glanduloso; lâmina 4,3-9,2 × 1,8$3,8 \mathrm{~cm}$, elíptica, oval a oboval, base cuneada, ápice obtuso, arredondado a apiculado, margem fortemente revoluta; face adaxial serícea a glabrescente; a abaxial serícea, com 8 ou mais glândulas marginais. Umbelas 3-6-floras; brácteas 0,7-1,9 mm compr.; bractéolas 0,4-1,1 mm compr., ovais; pedicelos 4,3-9,7 $\mathrm{mm}$ compr., pedunculados. Sépalas 1-2,1 × 0,9-1,3 mm, ápice plano, seríceo-ferrugíneas; as laterais biglandulosas, a anterior eglandulosa. Pétalas amarelas, crassas; as laterais reflexas, limbo 2,9-4,1 $\times$ 1,7-2,4 mm, margem denticulada; a posterior ereta a sub-reflexa, limbo 2,9-3,4 × 2,1-2,9 mm, margem glanduloso-denticulada. Estames iguais; filetes pilosos na base, 1,4-2,1 mm compr.; anteras glabras, eretas. Ovário seríceo; estiletes 1,1-1,6 $\mathrm{mm}$ compr., retos, divergentes distalmente, não arqueados na base, glabros, ápice dorsalmente truncado ou arredondado; estigmas laterais, voltados para o centro da flor ou raro para cima. Samarídeos seríceos; ala dorsal 22-55 $\mathrm{mm}$ compr.; núcleo seminífero liso.
Distribuição restrita à Floresta Atlântica da Bahia (Anderson 1993, Amorim 2014). E9, G8/9, H8, I8, J8: em restingas e mussunungas, a cerca de 90 m s.n.m. Coletada com flores de outubro a janeiro e com frutos em janeiro e dezembro.

Material selecionado - Belmonte, $16^{\circ 0} 00^{\prime} 52^{\prime \prime} \mathrm{S}, 39^{\circ} 04^{\prime} 16^{\prime \prime} \mathrm{W}, 8$ jan. 2002 (fr.), T.S. Nunes et al. 808 (HUEFS); Caravelas, 17²42'56"S, 39¹1'55"W, 12 dez. 2011 (bot.), E.N. Matos et al. 935 (HUEFS); Ilhéus, 14'54'S, 39 01'W, 5 jan. 1977 (fr.), R.M. Harley et al. 17807 (parátipos CEPEC, RB); Maraú, 1406'11"S, 3900'53"W, 26 fev. 1980 (bot.), A.M. Carvalho et al. 213 (parátipo CEPEC); Mata de São João, $12^{\circ} 31^{\prime} \mathrm{S}, 38^{\circ} 17^{\prime} \mathrm{W}, 28 \mathrm{dez} .2005$ (fr.), C.M. Menezes 363 (HRB, HUEFS, MBM); Porto Seguro, 16 $26^{\circ} \mathrm{S}$, $39^{\circ} 03^{\prime} \mathrm{W}, 18$ out. 1973 (bot., fl.), A. Eupunino 330 (holótipo CEPEC, isótipo MICH foto); Salvador, $12^{\circ} 58^{\prime} 16^{\prime \prime S}, 38^{\circ} 30^{\prime} 39^{\prime \prime} \mathrm{W}$, 22 maio 1981 (bot.), A.M. Carvalho et al. 692 (parátipos CEPEC, NY foto); Santa Cruz Cabrália, 16016'41"S, 3901'29"W, $12 \mathrm{dez}$. 1991 (fl.), S.C. Sant'Ana et al. 139 (parátipos CEPEC, SP); Santo

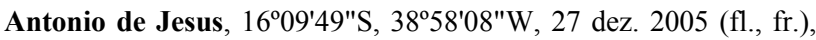
T.S. Nunes et al. 1393 (HUEFS, NY foto).

Heteropterys alternifolia é caracterizada pelas folhas alternas a subopostas, raro opostas, lâmina foliar com margem fortemente revoluta, pedicelos 4,3-9,7 mm compr. e samarídeos com núcleo seminífero liso. Assemelha-se a $H$. andersonii por apresentar pecíolo com indumento seríceo a glabrescente e pétala posterior com margem glanduloso-denticulada, mas difere pela filotaxia, forma das margens da lâmina foliar e pétalas laterais, além da pilosidade das anteras. Heteropterys alternifolia está posicionada na série Metallophyllis Nied., juntamente com $H$. andersonii, $H$. arenaria, $H$. chrysophylla, $H$. coleoptera, $H$. macrostachya e $H$. nitida. Estas espécies compartilham lâminas foliares com indumento dourado ou metálicoseríceo na face abaxial e em geral possuem os filetes pilosos (Anderson 1993; Amorim 2004). Não consta na lista de espécies ameaçadas da flora brasileira (Amorim et al. 2013).

3. Heteropterys andersonii Amorim, Brittonia 56: 143. 2004.

Figura 1; Amorim (2004: fig. 1).

Arbusto ou liana, 1-10 $\mathrm{m}$ alt. Folhas membranáceas a cartáceas; pecíolo 3-6 $\mathrm{mm}$ compr., seríceo a glabrescente, eglanduloso; lâmina 5,5-13,5 × 2,5-6,1 cm, oblonga, oblanceolada, oboval ou lanceolada, base obtusa ou cuneada, ápice agudo, obtuso, arredondado ou acuminado, margem plana; face adaxial glabra; a abaxial serícea, com 2 glândulas basais conspícuas e várias glândulas marginais. Umbelas ou corimbos 3-6-floros ou multifloros; brácteas 1,2-1,4 mm compr.; bractéolas 0,9-1,3 $\mathrm{mm}$ compr., ovais; pedicelos 5,5-8,2 mm compr., pedunculados. Sépalas 1,5-1,8 × 1,1-1,4 mm, ápice plano, seríceo-castanhas; as laterais biglandulosas, a anterior eglandulosa. Pétalas amarelas, crassas; as laterais subreflexas a patentes, limbo 3,1-3,5 × 2,3-2,9 $\mathrm{mm}$, margem erosa; a posterior ereto-patente, limbo 3,1-3,5 $\times$ 2,2-2,4 $\mathrm{mm}$, margem glanduloso- 
denticulada. Estames iguais; filetes pilosos na base, 1,9-2,5 mm compr.; anteras seríceas a glabrescentes, ressupinadas. Ovário seríceo; estiletes 1,6-1,9 $\mathrm{mm}$ compr., retos, divergentes distalmente, não arqueados na base, glabros, ápice dorsalmente apiculado; estigmas laterais, voltados para o centro da flor. Samarídeos seríceos a glabrescentes; ala dorsal 29,847,1 mm compr.; núcleo seminífero liso.

Distribuição restrita à Floresta Atlântica da Bahia (Amorim 2004, 2014): G8, H8: em florestas estacionais semideciduais, entre 180 e 330 m s.n.m. Coletada com flores de novembro a março e com frutos em abril.

Material selecionado - Almadina, 14'38'27"S, 39² $42^{\prime} 47^{\prime \prime} \mathrm{W}$, s.d. (fl.), P. Fiaschi et al. 2773 (CEPEC); Itaju do Colônia, 1509'12"S, 39³9'27"W, 4 jan. 2000 (fl.), A.M. Amorim et al. 3223 (holótipo CEPEC, isótipos HUEFS, SP, UESC); Potiraguá, 15²2'38"S, 3958'28"W, 2 nov. 2000 (fl.), J.G. Jardim et al. 3141 (CEPEC).

Heteropterys andersonii é caracterizada pela lâmina foliar com duas glândulas basais conspícuas, além de glândulas marginais. Assemelha-se a $H$. alternifolia (ver comentário daquela espécie). Outra característica evidente neste táxon e pouco documentada para o gênero, são as flores com odor quando em antese (Amorim 2004). Pertence à série Metallophyllis e não consta na lista de espécies ameaçadas da flora brasileira (Amorim et al. 2013).

4. Heteropterys arenaria Markgr., Notizbl. Bot. Gart. Berlin-Dahlem 15: 219. 1940.

Figuras 2, 17A-E e 24G-H.

Arbusto, 1-4 m alt. Folhas cartáceas; pecíolo 3,510,1 mm compr., seríceo, ápice biglanduloso; lâmina 2,1-6,5 × 1,2-3,4 cm, elíptica a oval, base cuneada a oblíqua, ápice obcordado-mucronado, margem revoluta; face adaxial glabra; a abaxial serícea, com 8 ou mais glândulas marginais. Umbelas 4-floras;

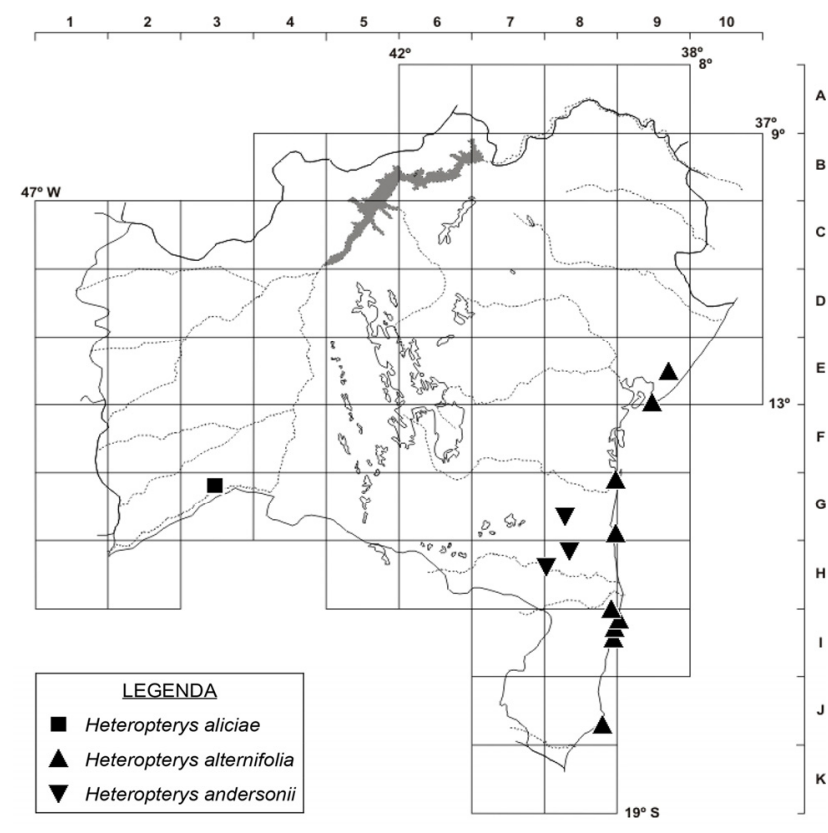

Figura 1. Mapa de distribuição de Heteropterys aliciae, $H$. alternifolia e $H$. andersonii no estado da Bahia. brácteas 1,5-2,3 mm compr; bractéolas 1,6-2,2 mm compr., ovais; pedicelos 2,7-4,9 mm compr., pedunculados. Sépalas 2,2-3 × 1,3-1,7 $\mathrm{mm}$, ápice plano, seríceo-ferrugíneas; as laterais biglandulosas, a anterior eglandulosa. Pétalas amarelas, crassas, margem erosa; as laterais patentes a sub-reflexas, limbo 3,6-3,9 $\times 1,8-2,2 \mathrm{~mm}$; a posterior ereto-patente, limbo 3-4,1 $\times$ 1,9-3,1 mm. Estames iguais; filetes pilosos na base, 0,9-1,5 mm compr.; anteras glabras, eretas. Ovário seríceo; estiletes 1,2-1,6 $\mathrm{mm}$ compr., retos, paralelos entre si, não arqueados na base, glabros, ápice dorsalmente arredondado ou obtuso; estigmas laterais, voltados para o centro da flor. Samarídeos seríceos; ala dorsal 12,8-22,7 mm compr.; núcleo seminífero com nervuras e cristas laterais inconspícuas.

Ocorre na Bahia e em Minas Gerais (Amorim 2004, 2014). B6, C6, D6, E5/6, F6, G5: em campos rupestres, ocasionalmente em transição para cerrados, entre 850 e 1170 m s.n.m. Coletada com flores de dezembro a março e em julho e com frutos em julho e agosto.

Material selecionado - Abaíra, 1319'S, 41²49'W, 4 jul. 1994 (fr.), W. Ganev 3458 (HUEFS); Barra do Mendes, $12^{\circ} 09^{\prime} 03^{\prime \prime S}$, 42 01'03"W, 16 dez. 2009 (fl.), E. Melo et al. 7617 (HUEFS); Caetité, 14¹5'37"S, 42³1'27"W, 8 mar. 1994 (f1.), N. Roque et al. CFCR 14949 (CEPEC, MBM, NY foto); Licínio de Almeida, 14 35'09"S, 42³2'23"W, 19 jul. 2012 (fl.), N. Roque et al. 3602

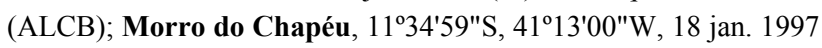
(fl.), M.M. Arbo et al. 7460 (CEPEC, SP); Mucugê, 130.'20"S, 4129'06"W, 1 fev. 2003 (bot., fl.), F. França et al. 4167 (CEPEC, HUEFS); Rio de Contas, 132' S, 41 ${ }^{\circ} 47^{\prime} \mathrm{W}, 27$ jul. 1993 (fl.), $W$. Ganev 2716 (HUEFS); Sento Sé, 27 jan. 2010 (bot., fl.), J.G. Carvalho-Sobrinho et al. 2548 (HVASF); Umburanas, 10²6'28"S, 41 ${ }^{\circ} 17^{\prime} 39^{\prime \prime W}, 15$ jul. 2004 (bot.), P. Fiaschi et al. 2443 (CEPEC);

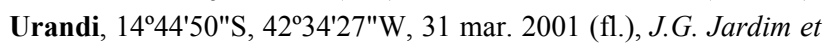
al. 3338 (ALCB, CEPEC, HUEFS, NY foto).

Heteropterys arenaria é caracterizada pela lâmina foliar 2,1-6,5 cm compr., ápice obcordado-mucronado, indumento da face abaxial castanho-dourado, seríceo, com oito ou mais glândulas que dão uma característica levemente denticulada à margem da lâmina foliar, inflorescência com as últimas unidades em umbelas 4floras e estiletes paralelos entre si. Assemelha-se a $H$. chrysophylla por ambas apresentarem hábito arbustivo e pecíolo biglanduloso, porém diferem pela forma do ápice da lâmina foliar, últimas unidades da inflorescência e disposição dos estiletes. Além das características diagnósticas supracitadas para $H$. arenaria, os samarídeos podem ter as alas dorsais consideradas relativamente pequenas $(12,8-22,7 \mathrm{~mm}$ compr.) quando comparadas às das demais espécies de sua série (ser. Metallophyllis) no estado. Não consta na lista de espécies ameaçadas da flora brasileira (Amorim et al. 2013).

5. Heteropterys bicolor A.Juss., Fl. Bras. Merid. 3: 23. 1833.

Figura 2; Anderson et al. (2006).

Arbusto, 2-4 m alt. Folhas membranáceas; pecíolo 4,2-9,3 mm compr., seríceo a glabrescente, base com 2 
glândulas estipitadas; lâmina 3,3-11,6 × 1,3-5 cm, elíptica ou oval, base obtusa ou cuneada, ápice acuminado, margem revoluta; ambas as faces glabrescentes; a abaxial com 2 glândulas próximo à base. Corimbos 8-12-floros; brácteas $0,8-1,6 \mathrm{~mm}$ compr.; bractéolas $0,9-1,4 \mathrm{~mm}$ compr., ovais; pedicelos 2,5-9,3 mm compr., pedunculados. Sépalas 1,4-1,8 $\times \quad 0,5-1,1 \mathrm{~mm}$, ápice plano, seríceoesverdeadas; as laterais biglandulosas, a anterior eglandulosa. Pétalas alvas, a posterior com mácula vinácea no limbo, crassas, margem erosa; as laterais patentes, limbo 2,9-4,1 × 1,7-2,4 mm; a posterior ereto-patente, limbo 3,1-3,2 × 1,8-2,3 mm. Estames desiguais; filetes glabros, $0,6-1,4 \mathrm{~mm}$ compr.; anteras glabras, eretas ou ressupinadas. Ovário seríceo; estiletes $0,9-1,3 \mathrm{~mm}$ compr., retos, divergentes distalmente, não arqueados na base, o anterior maior e inclinado para a sépala anterior, os posteriores mais largos que o anterior, glabros, ápice dorsalmente apiculado-uncinado; estigmas laterais, voltados para o centro da flor. Samarídeos seríceos a glabrescentes; ala dorsal 23,6-50,6 mm compr.; núcleo seminífero com nervuras laterais conspícuas.

Ocorre na Argentina e Brasil (BA, ES, MG, MS, PR, RJ e SP) na Floresta Atlântica (Amorim 2014). G8, H8: em florestas estacionais semideciduais, ca. $200 \mathrm{~m}$ s.n.m. Coletada com flores em novembro e dezembro e com frutos em janeiro e junho.

Material selecionado - Floresta Azul, 14⒌'36"S, 39³9'35"W, 26 dez. 1995 (bot.), M.L. Guedes et al. 3777 (ALCB, CEPEC); Jussari, 1509'29"S, 39³1'43"W, 21 nov. 1998 (fl.), A.M. Amorim et al. 2710 (CEPEC, SP).

Heteropterys bicolor é caracterizada pela presença de duas glândulas estipitadas na base do pecíolo, cada sépala latero-posterior com uma glândula decorrente ao pedicelo, pétalas laterais alvas e a posterior com uma mácula vinácea no limbo. Estas características são reportadas apenas para esta espécie de Heteropterys. Pertence à série Xanthopetalis e não consta na lista de espécies ameaçadas da flora brasileira (Amorim et al. 2013).

6. Heteropterys brunnea Sebastiani \& Mamede, Hoehnea 37(2): 341. 2010.

Figura 2; Sebastiani \& Mamede (2010: fig. 1).

Liana, ca. $4 \mathrm{~m}$ alt. Folhas membranáceas; pecíolo 4-7 mm compr., tomentoso a glabrescente, eglanduloso; lâmina $5-11,8 \times 1-6,2 \mathrm{~cm}$, elíptica ou oboval, base obtusa, ápice agudo, mucronulado ou cuspidado, margem revoluta; face adaxial tomentosa a glabrescente; a abaxial tomentosa, com 10-12 glândulas marginais. Corimbos 2-4-floros; brácteas 1,9-3,8 mm compr.; bractéolas 1,9-4,5 mm compr., elípticas; pedicelos 5,5-9,8 mm compr., pedunculados. Sépalas 3,6-4,1 $\times \quad 0,9-2,1 \mathrm{~mm}$, ápice plano, tomentoso-castanho-claro; as laterais biglandulosas, a anterior eglandulosa. Pétalas amarelas, membranáceas; as laterais patentes, limbo 4,2-5,2 × 2,1-2,8 mm, margem erosa; a posterior patente, limbo $4,1-4,7 \times$

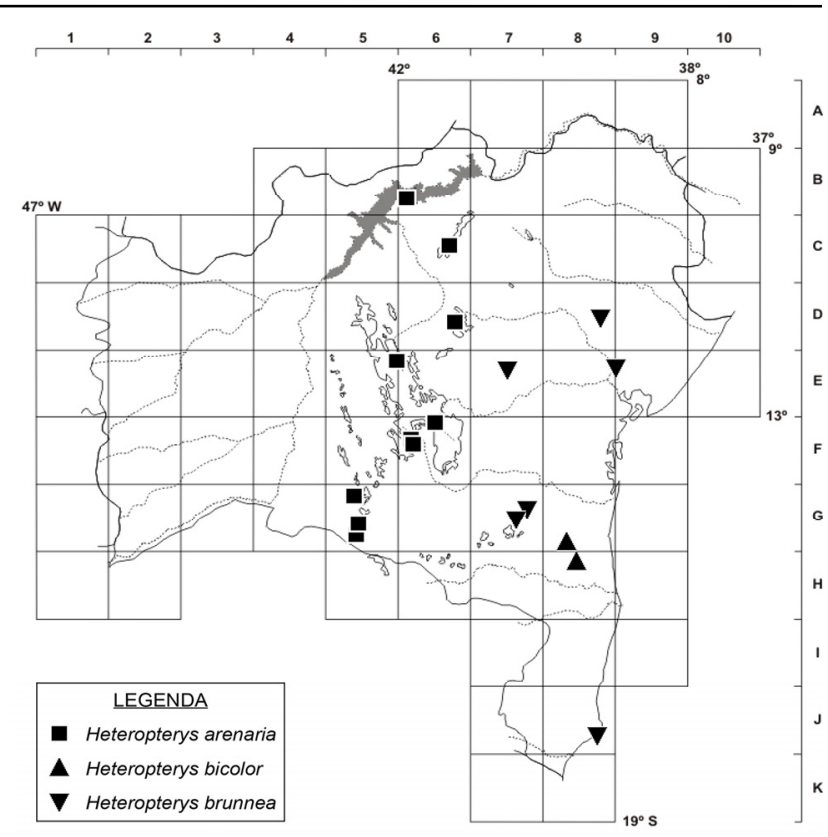

Figura 2. Mapa de distribuição de Heteropterys arenaria, H. bicolor e H. brunnea no estado da Bahia.

2,5-3,1 mm, margem glanduloso-espessada na base a erosa no ápice. Estames desiguais; filetes glabros, 2,53,5 mm compr.; anteras pilosas, eretas. Ovário seríceo; estiletes 2,8-3,5 $\mathrm{mm}$ compr., retos, divergentes distalmente, não arqueados na base, glabros, ápice dorsalmente arredondado ou levemente truncado; estigmas laterais, o anterior voltado para o centro da flor, os posteriores para as pétalas latero-posteriores. Samarídeos tomentosos; ala dorsal 22,6-23,2 mm compr.; núcleo seminífero com nervuras laterais conspícuas.

Ocorre na Bahia e no Espírito Santo (Sebastiani \& Mamede 2010; Amorim 2014). D8, E7, E8/9, G7, J8: em florestas estacionais semideciduais e deciduais, com uma população detectada em floresta ombrófila no município de Caravelas, entre 520 e 940 m s.n.m. Coletada com flores em março, setembro e novembro e com frutos em fevereiro e dezembro.

Material selecionado - Boa Nova, $14^{\circ} 21^{\prime} 45^{\prime \prime} \mathrm{S}, 40^{\circ} 12^{\prime} 27^{\prime \prime} \mathrm{W}, 22$ nov. 2012 (fl.), G.S. Brandão et al. 142 (HUESB); Caravelas, 17 $43^{\prime} \mathrm{S}, 39^{\circ} 15^{\prime} \mathrm{W}, 13$ mar. 2013 (fl.), T. Araújo \& M. Nogueira 209 (CEPEC); Conceição do Coité, $11^{\circ} 30^{\prime} 33^{\prime \prime S}, 39^{\circ} 12^{\prime} 5^{\prime \prime} \mathrm{W}, 2$ nov. 2011 (fl.), D.N. Carvalho 41 (HUEFS); Feira de Santana, $12^{\circ} 15^{\prime}$ S, $38^{\circ} 58^{\prime} \mathrm{W}, 20$ set. 1980 (fl.), L.R. Noblik 2009 (parátipos CEPEC, HUEFS); Poções, 14²36'40"S, 40²0'13"W, 7 fev. 2004 (fr.), W.W. Thomas et al. 13943 (parátipo CEPEC); Rui Barbosa, 12 $18^{\prime} 9^{\prime \prime} \mathrm{S}$, 40²9'15"W, 19 dez. 2004 (fr.), L.P. Queiroz et al 9942 (HUEFS).

Heteropterys brunnea é caracterizada pelo indumento tomentoso, alvo-acinzentado na face abaxial da lâmina foliar, pétala posterior com margem glandulosa na base, inflorescências com últimas unidades em corimbos 2-4-floros e anteras pilosas. Está posicionada na subseção Stenophyllarion (Griseb.) Nied., juntamente com $H$. intermedia, $H$. leschenaultiana e $H$. wiedeana, assemelhando-se a elas pela presença de glândulas na face abaxial da lâmina 
foliar ou na base do pecíolo, flores organizadas em corimbos 4-6-floros, pedúnculos e pedicelos delgados (Sebastiani \& Mamede 2010). Entretanto, difere dessas espécies pela lâmina foliar com indumento tomentoso na face abaxial, pétala posterior com margem glandulosa e anteras pilosas. Não consta na lista de espécies ameaçadas da flora brasileira (Amorim et al. 2013).

7. Heteropterys bullata Amorim, Brittonia 54: 223. 2002. Figura 3; Amorim (2002: fig. 4).

Liana, 3-7 m alt. Folhas membranáceas; pecíolo 32-48 mm compr., glabro, base biglandulosa; lâmina 7,9-14,2 × 3,2-9,5 cm, oblonga, oval, cordado-oblonga ou elíptica, base cordada, raro cuneada, ápice obtuso, arredondado ou retuso, margem plana; face adaxial glabra; a abaxial tomentosa, com 8 ou mais glândulas marginais. Corimbos 4-8-floros ou umbelas 4-floras; brácteas $0,9-1,1 \mathrm{~mm}$ compr.; bractéolas $0,5-1 \mathrm{~mm}$ compr., ovais; pedicelos 4,8-8 mm compr., sésseis. Sépalas 1,6-1,8 $\times 1,4-1,6 \mathrm{~mm}$, ápice plano, tomentoso-ferrugíneas; as laterais biglandulosas, a anterior eglandulosa. Pétalas amarelas, crassas; as laterais patentes, limbo 3,4-3,8 × 2,7-3 mm, margem inteira; a posterior ereta, limbo 2,5-3 × 2,7-2,9 mm, margem glanduloso-espessada. Estames desiguais; filetes glabros, 2-2,8 mm compr.; anteras glabras, eretas. Ovário seríceo; estiletes 3-3,2 mm compr., retos, o anterior inclinado em direção à pétala posterior, os posteriores arqueados na base, glabros, o anterior com ápice dorsalmente truncado ou arredondado, os posteriores arredondados; estigmas laterais, voltados para o centro da flor. Samarídeos tomentosos a glabrescentes; ala dorsal 29-52 $\mathrm{mm}$ compr.; núcleo seminífero liso.

Distribuição restrita à Floresta Atlântica da Bahia (Amorim 2003a, 2014). F8, G8, H8: em florestas ombrófilas montanas, raro submontanas, entre 550 e 850 m s.n.m. Coletada com flores em abril, maio, julho e setembro e com frutos em abril, junho e julho.

Material selecionado - Arataca, $15^{\circ} 10^{\prime} 42^{\prime \prime}$ S, 39 $20^{\prime} 09^{\prime \prime} \mathrm{W}, 12$ set. 2009 (bot., fl.), L. Daneu 127 (CEPEC); Barro Preto, 1446'26"S, 39³2'32"W, 28 jul. 2011 (fr.), R.O. Perdiz et al. 839 (CEPEC, RB); Camacan, 15'23'35"S, 39 33'53"W, 14 abr. 2007 (fl.), A.M. Amorim et al. 7013 (CEPEC); Floresta Azul, 1456'8"S, 3941'58"W, 12 abr. 2001 (fr.), J.G. Jardim et al. 3440 (holótipo CEPEC); Tancredo Neves, 1326'36"S, 39³0'40"W, 21 maio 2005 (bot., fl.), A.M. Amorim et al. 5044 (CEPEC); Uruçuca, 14²9'58"S, 3906'54"W, 21 abr. 2004 (fl.), A.M. Amorim et al. 3981 (CEPEC);

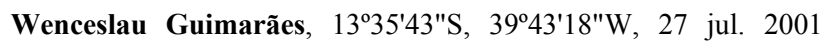
(bot., fl.), L.A. Mattos-Silva et al. 4488 (parátipos ALCB, CEPEC, UESC).

Heteropterys bullata é caracterizada pelo pecíolo de 32-48 mm compr. e a lâmina foliar fortemente bulada. Está posicionada na subseção Aptychia Nied., juntamente com $H$. catingarum, $H$. conformis, H. cordifolia, H. imperata, H. jardimii, H. nordestina, H. oberdanii e $H$. sanctorum. As espécies desta subseção apresentam pedicelos sésseis (Amorim 2003) e $H$. bullata difere prontamente delas por apresentar folhas buladas. É uma espécie em perigo de extinção (Amorim et al. 2013).

8. Heteropterys byrsonimifolia A.Juss., Ann. Sci. Nat., Bot. II, 13: 276. 1840.

Figuras 3 e $18 \mathrm{~A}-\mathrm{E}$.

Arbusto ou arvoreta, 0,5-4 $\mathrm{m}$ alt. Folhas coriáceas; pecíolo 2,8-5,6 $\mathrm{mm}$ compr., seríceo a glabrescente, eglanduloso; lâmina 2,5-11 × 1,5-5,2 cm, oval, raro oboval, base obtusa, arredondada ou subcordada, ápice obtuso a arredondado, raro acuminado, margem revoluta; ambas as faces seríceas a glabrescentes; a abaxial com 4-6 glândulas intramarginais ou eglandulosa. Corimbos 2-12-floros; brácteas 1-1,9 $\mathrm{mm}$ compr.; bractéolas 2-2,5 $\mathrm{mm}$ compr., elípticas; pedicelos 3-6 mm compr., pedunculados. Sépalas 2,5$3,4 \times 1,8-2,2 \mathrm{~mm}$, ápice revoluto, tomentosoferrugíneas; as laterais biglandulosas, a anterior eglandulosa. Pétalas amarelas, membranáceas, margem erosa; as laterais sub-reflexas a reflexas, limbo 5,2-6,5 × 4-5,2 $\mathrm{mm}$; a posterior ereta a ereto-patente, limbo 4,7-5 × 4-4,2 mm. Estames iguais; filetes glabros, 2,3-2,7 $\mathrm{mm}$ compr.; anteras pilosas a glabrescentes, eretas a ressupinadas. Ovário tomentoso; estiletes 2-2,2 $\mathrm{mm}$ compr., retos, divergentes distalmente, não arqueados na base, glabros, ápice dorsalmente apiculado-uncinado; estigmas laterais, o anterior voltado para o centro da flor, os posteriores para a pétalas latero-posteriores. Samarídeos tomentosos; ala dorsal 12,7-30 $\mathrm{mm}$ compr.; núcleo seminífero com nervuras laterais inconspícuas.

Ocorre na Bahia, Distrito Federal, Goias, Mato Grosso, Mato Grosso do Sul, Minas Gerais, Paraná e São Paulo (Mamede 2004; Amorim 2014). B4, B5, C6, C7, C8, D4, D5, D6, E3, E5, E6, F6, F7, G3, G5, G7: em campos rupestres e cerrados, entre 420 e $1450 \mathrm{~m}$ s.n.m. Coletada com flores de maio a dezembro e com frutos de abril a junho, e de agosto a dezembro.

Material selecionado - Abaíra, $13^{\circ} 18^{\prime} \mathrm{S}, 41^{\circ} 53^{\prime} \mathrm{W}, 26$ out. 1992 (fl., fr.), W. Ganev 1354 (HUEFS, SP); Baianopólis, 12²16'S, 443' 'W, 6 jun. 1996 (fl.), F. França et al. 1689 (HUEFS); Barra,

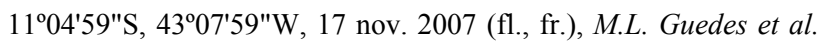
14500 (ALCB); Barra do Mendes, $11^{\circ} 48^{\prime} 27^{\prime \prime S}, 42^{\circ} 14^{\prime} 05^{\prime \prime} \mathrm{W}, 25$ out. 2009 (fl., fr.), M.L. Guedes et al. 16117 (ALCB, HUEFS); Brotas de Macaúbas, 120'34"S, 4243'50"W, 2 jun. 2007 (est.), A.A. Conceição et al. 2129 (HUEFS); Caetité, 14¹9'24"S, 42 $33^{\prime} 25^{\prime \prime W}$, abr. 2008 (fr.), M.S. Mendes et al. 473 (HUEFS); Campo Alegre de Lourdes, 09 $30^{\prime} 13^{\prime \prime} \mathrm{S}, 4^{\circ} 02^{\prime} 40^{\prime \prime} \mathrm{W}, 30$ set. 2005 (fl., fr.), D. Cardoso et al. 848 (HUEFS); Cocos, $14^{\circ} 11^{\prime} \mathrm{S}, 44^{\circ} 32^{\prime} \mathrm{W}$, 11 ago. 1996 (fl.), M.S. Ferrucci et al. 1007 (CEPEC, HUEFS, MBM); Ibitiara, 12³7'36"S, 42 $16^{\prime} 06^{\prime \prime} \mathrm{W}, 11$ out. 2007 (bot., fl.), A.A. Conceição 2526 (CEPEC, HUEFS); Jaguarari, 1002'S, $40^{\circ} 13^{\prime} \mathrm{W}, 10$ nov. 2005 (fl., fr.), A.A. Conceição et al. 1604 (HUEFS); Licínio de Almeida, 14³4'11"S, 42²7'59"W, 11 dez. 2009 (fr.), F.S. Gomes et al. 382 (ALCB, HUEFS); Maracás, 132'ㄷ'S, 40²3'51"W, 27 out. 2012 (fl., fr.), E. Melo et al. 11688

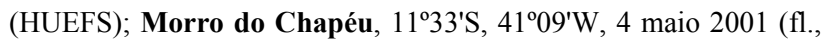


fr.), A.M. Amorim 3663 (CEPEC); Mucugê, 12 59'30"S, $41^{\circ} 20^{\prime} 30^{\prime \prime W}, 24$ out. 2000 (fl.), E.R. Souza et al. 85 (HUEFS); Oliveira dos Brejinhos, $12^{\circ} 22^{\prime} \mathrm{S}, 42^{\circ} 54^{\prime} \mathrm{W}, 18 \mathrm{dez} .2007$ (fr.), A.A. Conceição et al. 2787 (HUEFS); Palmeiras, 12²5'47"S, 4129'51"W, 12 nov. 2011 (fl.), S. Lua 8 (HUEFS); Piatã, 1309'S, 4136'W, 13 out. 2006 (fr.), M.L. Guedes et al. 12784 (ALCB); Pilão Arcado, 09 57'06"S, 42 43'50"W, 8 set. 2005 (bot., fl.), A. Rapini et al. 1262 (HUEFS); Pindobaçu, 104 $44^{\prime} \mathrm{S}, 40^{\circ} 21^{\prime} \mathrm{W}, 6$ dez. 2003 (fl., fr.), A.M. Miranda et al. 4375 (HUEFS); Remanso, 09²4'53"S, 42 $19^{\prime} 17^{\prime \prime W}, 24$ set. 2009 (f1.), M.L. Guedes et al. 16035 (ALCB, HUEFS); Rio de Contas, 13 $35^{\prime} 47^{\prime \prime} \mathrm{S}, 41^{\circ} 49^{\prime} 23^{\prime \prime} \mathrm{W}$, 26 set. 2010 (fl.), R.M. Harley et al. 56153 (HUEFS); Seabra, $12^{\circ} 25^{\prime} 07^{\prime \prime S}, 41^{\circ} 46^{\prime} 13^{\prime \prime W}, 9$ out. 2005 (fl.), L.A. Mattos-Silva 4950

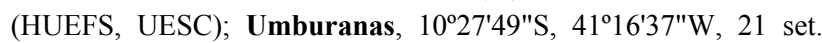
2006 (bot., fl.), J.A. Siqueira-Filho 1754 (CEPEC); Vitória da Conquista, $14^{\circ} 50^{\prime} \mathrm{S}, 40^{\circ} 48^{\prime} \mathrm{W}, 30$ out. 2013 (fl., fr.), L.C. Marinho et al. 505 (CEPEC, HUEFS); Xique-xique, $11^{\circ} 03^{\prime} 44^{\prime \prime S}$, $42^{\circ} 58^{\prime} 53^{\prime \prime} \mathrm{W}, 26$ jun. 2005 (bot.), D.S. Carneiro-Torres et al. 538 (HUEFS).

Heteropterys byrsonimifolia é caracterizada pelo pecíolo seríceo a glabrescente, folhas ovais, inflorescências com últimas unidades florais em corimbos 2-12-floros e filetes de 2,3-2,7 mm compr. Assemelha-se a $H$. escallonifolia, pelas folhas apressas aos ramos e face abaxial da lâmina foliar pilosa, mas difere pela lâmina foliar de 2,5-11 × 1,5-5,2 cm, geralmente oval e base obtusa a arredondada (vs. lâmina foliar $1,8-5 \times 0,7-2,1 \mathrm{~cm}$, oblanceolada a elíptica e base cuneada em $H$. escalloniifolia). Heteropterys byrsonimifolia é uma das sete espécies do subgênero Parabanisteria (C.V.Morton) C.V.Morton na Bahia (H. coriacea, $H$. eglandulosa, $H$. escalloniifolia, $H$. grandiflora, $H$. macradena e $H$. nervosa). Este grupo é encontrado preferencialmente em áreas de cerrados e campos rupestres, sendo caracterizado pelo hábito arbustivo, chegando a arvoretas, raramente lianas, estípulas interpeciolares, sépalas encobrindo completamente as pétalas na préantese e ápice revoluto pós-antese (Amorim 2003a). Não consta na lista de espécies ameaçadas da flora brasileira (Amorim et al. 2013).

9. Heteropterys caducibracteata W.R.Anderson, Contr. Univ. Michigan Herb. 15: 118. 1982.

Figura 4; Anderson (1982: fig. 9).

Arbusto ou liana, 1-1,5 $\mathrm{m}$ alt. Folhas membranáceas a cartáceas; pecíolo 1,5-9 mm compr., tomentoso a velutino, eglanduloso; lâmina 1,7-7,3 × 1-4 cm, elíptica, oval, raro oboval, base cuneada, ápice obtuso, agudo, raro cuspidado, margem revoluta; face adaxial tomentosa a glabrescente; a abaxial tomentosa, com 1 ou 2 glândulas intramarginais ou eglandulosa. Corimbos 10-20-floros; brácteas 1,9-2,9 mm compr.; bractéolas 2,5-3,5 mm compr., lineares; pedicelos $3-$ 5,6 mm compr., pedunculados. Sépalas 1,2-2 × 2,4-3 $\mathrm{mm}$, ápice plano, tomentoso-ferrugíneas; todas biglandulosas ou somente a anterior eglandulosa. Pétalas róseas, com margem alva, crassas, carenadas; as laterais reflexas, limbo 4,8-6 × 2,3-3,3 mm, margem inteira a erosa; a posterior ereta a eretopatente, limbo 3,5-4,7 × 2,8-3,8 $\mathrm{mm}$, margem erosa. Estames desiguais; filetes glabros, 1,4-2,5 $\mathrm{mm}$ compr.; anteras glabras, eretas. Ovário seríceo; estiletes 1,8-2,3 $\mathrm{mm}$ compr., retos, divergentes distalmente, não arqueados na base, o anterior igual ou menor que os posteriores, glabros, ápice dorsalmente truncado ou obtuso; estigmas laterais, voltados para o centro da flor. Samarídeos seríceos; ala dorsal 23,231,6 mm compr.; núcleo seminífero com nervuras laterais conspícuas.

Ocorre na Bahia e no Piauí (Anderson 1982; Amorim 2014). B5/6, C5, C6, D6, E6, E7, G5, G7: em caatingas e contato caatingas/campos rupestres, entre 400 e 970 m s.n.m. Coletada com flores de dezembro a junho e com frutos de janeiro a março.

Material selecionado - Barra, $10^{\circ} 51^{\prime} \mathrm{S}, 42^{\circ} 40^{\prime} \mathrm{W}, 4$ fev. 2000

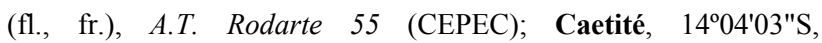
42 38'12"W, 9 fev. 1997 (fl.), M.L. Guedes et al. 5302 (ALCB, CEPEC, HUEFS); Campo Formoso, $10^{\circ} 25^{\prime} \mathrm{S}, 41^{\circ} 15^{\prime} \mathrm{W}, 7$ mar. 1976 (fl.), W.R. Anderson 11742 (isótipo MICH foto, NY foto);

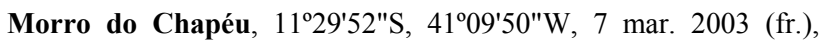
T.R.S. Silva et al. 183 (CEPEC, HUEFS); Mucugê, $13^{\circ} 00^{\prime S}$,

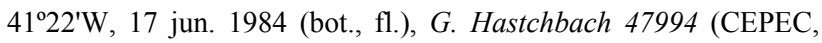
MBM); Pilão Arcado, 1001'25"S, 4248'15"W, 18 mar. 2006 (fl.), E.B. Miranda et al. 957 (HUEFS); Sento Sé, 0944'26"S, 41 $58^{\prime} 23^{\prime \prime W}, 27$ jan. 2008 (fr.), C. Correia et al. 409 (HUEFS); Vitória da Conquista, $14^{\circ} 51^{\prime} \mathrm{S}, 40^{\circ} 50^{\prime} \mathrm{W}, 15$ fev. 1972 (bot., fl.), T.S. Santos 2249 (CEPEC).

Heteropterys caducibracteata é caracterizada pelas brácteas e bractéolas lineares e decíduas após a antese. Morfologicamente, assemelha-se a $H$. perplexa e $H$. pteropetala, diferenciando pela deciduidade e forma das brácteas e bractéolas. Heteropterys caducibracteata é formalmente posicionada na série Rhodopetalis Nied., grupo caracterizado pelo pedúnculo floral reduzido (com relação ao pedicelo), pétalas alvas a róseas, estigmas lateralmente compressos e núcleo seminífero geralmente com cristas ou álulas laterais (Amorim 2003a). Este grupo está representado na Bahia por Heteropterys caducibracteata, $H$. perplexa, $H$. pteropetala, $H$. rubiginosa, $H$. rufula, $H$. sessilifolia e $H$. trigoniifolia. A espécie não consta na lista de espécies ameaçadas da flora brasileira (Amorim et al. 2013).

10. Heteropterys catingarum A.Juss., Arch. Mus. Hist. Nat. Paris 3: 443. 1843.

Figura 5; Amorim (2003a: fig. 58)

Liana, 1,5-3 $\mathrm{m}$ alt. Folhas membranáceas; pecíolo 6-11 mm compr., velutino a glabrescente, terço-médio ou ápice biglanduloso; lâmina 4,2-8,4 × 1,7-4,6 cm, elíptica, lanceolada, oboval, raro oblonga, base obtusa ou cuneada, ápice agudo, obtuso, raro retuso, margem revoluta; ambas as faces seríceas, com 6 ou mais glândulas marginais. Umbelas 4-8-floras; brácteas 22,3 $\mathrm{mm}$; bractéolas $0,8-1,1 \mathrm{~mm}$, ovais; pedicelos 9-12 mm compr., sésseis. Sépalas 2,1-2,5 × 1,3-1,7 mm, ápice plano, seríceo-castanho-claras; as laterais 
biglandulosas, a anterior eglandulosa. Pétalas amarelas, membranáceas, margem erosa; as laterais patentes a reflexas, limbo 2,5-3,1 × 2,2-2,5 $\mathrm{mm}$; a posterior ereta a ereto-patente, limbo 2,5-3 × 2,2-2,5 $\mathrm{mm}$. Estames desiguais; filetes glabros, 2,1-3,3 mm; anteras glabras, eretas. Ovário seríceo; estiletes 2,32,5 mm compr., curvilíneos, o anterior inclinado em direção à pétala posterior e maior que os posteriores, os posteriores arqueados na base, glabros, ápice dorsalmente obtuso; estigmas subapicais, voltados para o centro da flor. Samarídeos seríceos a glabrescentes; ala dorsal 37-47 mm compr.; núcleo seminífero liso.

Ocorre na Bahia, Ceará, Pará, Paraíba, Pernambuco, Piauí, Rio Grande do Norte e Sergipe (Amorim 2003a, 2014). B7, B8/9, E8, G6: em caatingas, entre 140 e 550 m s.n.m. Coletada com flores de janeiro a março e com frutos em janeiro, março e julho.

Material selecionado - Cachoeira, $12^{\circ} 32^{\prime} \mathrm{S}, 39^{\circ} 05^{\prime} \mathrm{W}$, fev. 1981 (bot., fl.), Pedra do Cavalo 1089 (ALCB, HUEFS); Canudos, 0956'35"S, 38 59'18"W, 17 fev. 2004 (fl.), R.M. Harley et al. 54880 (HUEFS); Juazeiro, 0944'40"S, 40 40'39"W, 26 mar. 2000 (fr.), N.G. Jesus et al. 882 (ALCB, CEPEC, HUEFS, RB);

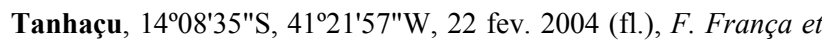
al. 4901 (HUEFS, RB).

Heteropterys catingarum é caracterizada pela lâmina foliar geralmente elíptica, com indumento seríceo, e persistente na face abaxial, pecíolo biglanduloso no terço-médio ou no ápice, pedicelo 9 $12 \mathrm{~mm}$ compr., estilete anterior levemente inclinado sobre os posteriores e o estigma subapical. No campo, apresenta pedicelos e glândulas do cálice de coloração verde, em contraste com as brácteas, bractéolas e sépalas de coloração castanho-clara (Amorim 2003a). Assemelha-se a $H$. conformis pelo padrão da inflorescência, pétalas laterais reflexas e a forma do androceu e dos estiletes. Entretanto, podem ser distinguidas pela lâmina foliar membranácea e indumento seríceo na face abaxial em $H$. catingarum (vs. lâmina foliar cartácea e face abaxial glabra em $H$. conformis) (Amorim 2003a). Pertence à subseção Aptychia e não consta na lista de espécies ameaçadas da flora brasileira (Amorim et al. 2013).

11. Heteropterys chrysophylla (Lam.) Kunth., Nov. Gen. Sp. 5: 163. 1822.

Figura 4; Curtis (1833: fig. 3237).

Arbusto, ca. $1 \mathrm{~m}$ alt. Folhas cartáceas; pecíolo 2,8 9,7 mm compr., seríceo, base biglandulosa; lâmina 1,7-11,4 × 1,4-6 cm, oval, base arredondada, ápice obtuso a retuso, obcordado ou arredondado, margem revoluta; face adaxial glabra; a abaxial serícea, com 8 ou mais glândulas marginais. Corimbos 10-floros, raro umbelas 6-floras; brácteas 1,7-2,7 mm; bractéolas 1,32,6 mm, ovais; pedicelos 4,1-11,4 $\mathrm{mm}$ compr., pedunculados. Sépalas 2,1-2,8 × 1,3-1,9 $\mathrm{mm}$, ápice plano, seríceo-ferrugíneas; as laterais biglandulosas, a anterior eglandulosa. Pétalas amarelas, crassas, margem erosa; as laterais sub-reflexas a patentes, limbo 3,3-4,6 × 2,7-3,7 mm; a posterior ereto-patente, limbo 2,9-3,6 × 3-3,3 mm. Estames iguais; filetes pilosos na base, $1,1-1,7 \mathrm{~mm}$; anteras glabras, eretas. Ovário seríceo; estiletes 0,8-1,2 $\mathrm{mm}$ compr., curvilíneos, divergentes distalmente, não arqueados na base, glabros, ápice dorsalmente apiculado ou obtusoapiculado; estigmas laterais, voltados para o centro da flor. Samarídeos seríceos; ala dorsal 13,1-41,3 mm compr.; núcleo seminífero com nervuras laterais conspícuas.

Ocorre da Bahia ao Paraná (Amorim 2004, 2014). E7, E8, F7, F8, G7, I8: em caatingas, ocasionalmente em restingas, entre 120 e 400 m s.n.m. Coletada com flores em março, setembro e outubro e com frutos em agosto e setembro.

Material selecionado - Cachoeira, $12^{\circ} 32^{\prime} \mathrm{S}, 39^{\circ} 05^{\prime} \mathrm{W}$, set. 1980 (bot., fl.), Pedra do Cavalo 743 (ALCB, CEPEC, HUEFS, RB); Itaberaba, $12^{\circ} 25^{\prime} 01^{\prime \prime} \mathrm{S}, 40^{\circ} 30^{\prime} 59^{\prime \prime} \mathrm{W}, 22$ abr. 2006 (est.), D. Cardoso 1264 (HUEFS); Itatim, 12²42'S, 3946'W, 29 set. 1996 (fl., fr.), F. França et al. 1872 (CEPEC, HUEFS); Ituberá, $13^{\circ} 43^{\prime} \mathrm{S}$, $39^{\circ} 08^{\prime} \mathrm{W}, 25$ jan. 2006 (est.), R.M. Valadão \& M.L. Guedes 169 (ALCB); Jequié, 135' $\mathrm{S}, 40^{\circ} 5^{\prime} \mathrm{W}, 20$ set. 1987 (bot., fl.), M.V.L. Pereira et al. 185 (CEPEC); Manoel Vitorino, $14^{\circ} 08^{\prime} \mathrm{S}, 40^{\circ} 14^{\prime} \mathrm{W}$, 29 set. 1979 (fr.), S.A. Mori 12832 (CEPEC); Porto Seguro, 16 $26^{\circ} \mathrm{S}, 39^{\circ} 05^{\prime} \mathrm{W}, 14$ set. 1998 (fl., fr.), A.M. Amorim et al. 2573 (CEPEC, SP, UESC).

Heteropterys chrysophylla é caracterizada pelo pecíolo biglanduloso na base, lâmina foliar coriácea, com ápice obtuso a retuso, inflorescências com últimas unidades em corimbos 10-floros, estigma lateral ou subapical e núcleo seminífero do samarídeo com nervuras laterais conspícuas. Assemelha-se a $H$. arenaria (ver comentário naquela espécie) e $H$. coleoptera na forma e indumento da face abaxial da lâmina foliar, mas difere pela posição das glândulas no pecíolo (glândulas no ápice em $H$. coleoptera), samarídeos com alas dorsais menores $(45,8-52,7 \mathrm{~mm}$ compr. em $H$. coleoptera) e nervuras laterais conspicuas (vs. álulas laterais em $H$. coleoptera). As populações detectadas na Bahia e algumas no Espírito Santo diferem das populações do Sudeste e Sul do Brasil e poderão ser segregadas em táxons distintos no futuro. Heteropterys chrysophylla pertence à série Metallophyllis e não consta na lista de espécies ameaçadas da flora brasileira (Amorim et al. 2013).

12. Heteropterys cochleosperma A.Juss., Ann. Sci. Nat. Bot. II, 13: 274. 1840.

Figuras 3, 19A-F e 23F, G.

Arbusto ou liana, 1-3 $\mathrm{m}$ alt. Folhas membranáceas; pecíolo 2-11,9 mm compr., seríceo, ápice biglanduloso; lâmina 1,5-9,5 × 0,8-4,4 cm, lanceolada ou oval, base cuneada ou arredondada, ápice acuminado ou cuspidado, margem revoluta; face adaxial glabra; a abaxial tomentosa, eglandulosa. Umbelas 4-floras ou corimbos 6-floros; brácteas 1,4-2 $\mathrm{mm}$ compr.; bractéolas 1-1,5 $\mathrm{mm}$ compr., ovais; pedicelos 3,1-4,2 mm compr., pedunculados. Sépalas 2-2,8 × 1-1,4 $\mathrm{mm}$, ápice plano, seríceo-castanhas, eglandulosas. Pétalas amarelas, membranáceas, 


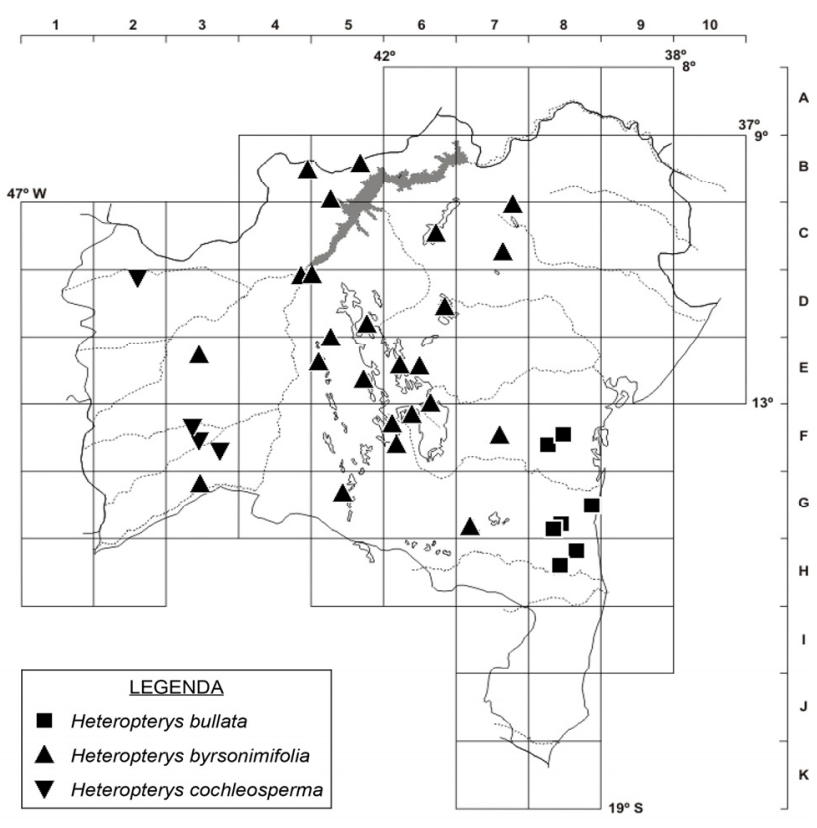

Figura 3. Mapa de distribuição de Heteropterys bullata, $H$. byrsonimifolia e $H$. cochleosperma no estado da Bahia.

margem erosa; as laterais sub-reflexas a reflexas, limbo 2,9-3,2 × 2,1-2,7 $\mathrm{mm}$; a posterior ereta a eretopatente, limbo 2,5-3 × 2-2,2 mm. Estames desiguais; filetes glabros, 1,1-2,1 mm compr.; anteras glabras, eretas. Ovário seríceo; estiletes 1,5-1,9 mm compr., retos, paralelos entre si, os posteriores arqueados na base, glabros, ápice dorsalmente apiculado ou arredondado; estigmas laterais, o anterior voltado para o centro da flor, os posteriores para as pétalas lateroposteriores. Samarídeos seríceos; ala dorsal 19,429,3 mm compr.; núcleo seminífero com nervuras laterais inconspícuas.

Ocorre em Goiás, Mato Grosso do Sul, Paraná e São Paulo (Amorim 2014). Sua ocorrência no Cerrado da Bahia é o primeiro registro da espécie para o Nordeste. D2, F3: em cerrados e florestas estacionais semideciduais e deciduais, entre 550 e 660 m s.n.m. Coletada com flores em março e abril e com frutos em junho e julho.

Material selecionado - Coribe, $13^{\circ} 41^{\prime} 28^{\prime \prime} \mathrm{S}, 4^{\circ} 15^{\prime} 28^{\prime \prime} \mathrm{W}, 7$ jun. 2007 (fr.), M.M.M. Lopes et al. 1330 (CEPEC, HUEFS);

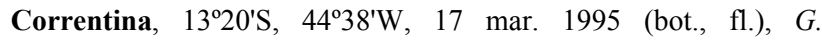
Hatschbach 62012 (CEPEC, MBM); Formosa do Rio Preto, $11^{\circ} 06^{\prime} 48^{\prime \prime} \mathrm{S}, 45^{\circ} 23^{\prime} 11^{\prime \prime W}, 15$ jul. 2009 (fr.), J. Neri et al. 58 (RB,

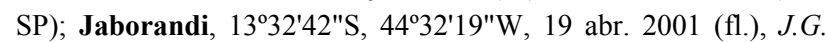
Jardim et al. 3714 (CEPEC, HUEFS).

Heteropterys cochleosperma é caraterizada pelo pecíolo de 2-11,9 $\mathrm{mm}$ compr., seríceo, com ápice biglanduloso, lâmina foliar lanceolado-oval, com face abaxial ferrugíneo-tomentosa, eglandulosa, sépalas eglandulosas e pétalas laterais sub-reflexas a reflexas. Assemelha-se a $H$. dumetorum, $H$. rhopalifolia e $H$. syringifolia pela posição das bractéolas no pedúnculo e anteras glabras, mas difere pela ausência de glândulas na face abaxial da lâmina foliar e nervuras inconspícuas no núcleo seminífero. Pertence à série
Xanthopetalis e não consta na lista de espécies ameaçadas da flora brasileira (Amorim et al. 2013).

Jussieu (1840) descreveu $H$. cochleosperma com pétalas amarelas, inserindo-a na série Xanthopetalis. No entanto, Niedenzu (1928) não informou a coloração das pétalas desta espécie e a posicionou na série Rhodopetalis (grupo exclusivamente com pétalas róseas a alvas). Anderson (1982) transferiu $H$. martiana A.Juss. (=H. syringifolia) e $H$. trichanthera para a série Xanthopetalis, mas $H$. cochleosperma continuou associada a Rhodopetalis. Assim, é proposta aqui a classificação de $H$. cochleosperma em Xanthopetalis, série caracterizada pelo pedúnculo de tamanho igual ou maior que o pedicelo, bractéolas geralmente inseridas um pouco abaixo do pedúnculo e flores bem desenvolvidas com pétalas amarelas.

13. Heteropterys coleoptera A.Juss., Ann. Sci. Nat., Bot. II, 13: 275.1840.

Figuras 5 e $17 \mathrm{~F}-\mathrm{L}$.

Arbusto, 2-10 m alt. Folhas cartáceas; pecíolo 4,9-13,3 mm compr., seríceo, ápice 2-4-glanduloso; lâmina 2,5-19,8 × 1,8-9 cm, elíptica, oboval a oval, base cuneada, raro arredondada, ápice obcordadomucronado, margem plana; face adaxial glabra; a abaxial serícea, com 6 ou mais glândulas marginais. Umbelas 2-4-floras; brácteas 1,5-1,9 mm compr.; bractéolas 1-1,3 mm compr., ovais; pedicelos 2,2-5,4 mm compr., pedunculados. Sépalas 1,9-2,3 × 0,6-0,9 $\mathrm{mm}$, ápice plano, seríceo-ferrugíneas; as laterais biglandulosas, a anterior eglandulosa. Pétalas amarelas, crassas, margem erosa; as laterais subreflexas a reflexas, limbo 3,8-4,2 × 1,9-2,3 $\mathrm{mm}$; a posterior ereta, limbo 3,7-4,2 × 2,7-3,1 mm. Estames iguais; filetes pilosos na base, $0,8-1 \mathrm{~mm}$; anteras glabras, eretas. Ovário seríceo; estiletes 1-1,5 $\mathrm{mm}$ compr., retos, divergentes distalmente, o anterior maior que os posteriores, glabros, ápice dorsalmente apiculado-uncinado; estigmas laterais, voltados para o centro da flor. Samarídeos seríceos; ala dorsal 45,8$52,7 \mathrm{~mm}$ compr.; núcleo seminífero com álulas laterais.

Ocorre na costa leste do Brasil, desde o Rio Grande do Norte até o Rio Grande so Sul (Amorim 2004, 2014). C7, F6, F8, F9, G8/9, H8, I8: em florestas ombrófilas montanas, submontanas e de terras baixas, entre 60 e 500 m s.n.m., com duas populações detectadas no domínio da Caatinga, uma em Rio de Contas e a outra em Saúde, possivelmente crescendo em florestas ciliares. Coletada com flores em janeiro, fevereiro, junho, outubro e novembro e com frutos em abril, agosto, novembro e dezembro.

Material selecionado - Cairu, $13^{\circ} 33^{\prime} \mathrm{S}, 39^{\circ} 02^{\prime} \mathrm{W}, 13$ nov. 2003 (fl., fr.), J.L. Paixão et al. 314 (CEPEC); Eunápolis, $16^{\circ} 22^{\prime} \mathrm{S}, 39^{\circ} 34^{\prime} \mathrm{W}, 21$ nov. 1995 (fl.), M.L. Guedes s.n. (ALCB 27480, CEPEC); Ilhéus, 1454'49"S, 3902'29"W, 19 fev. 2004 (fl.), S.C. Sant'Ana et al. 1103 (CEPEC, SP); Itacaré, 14¹6'S, $38^{\circ} 59^{\prime} \mathrm{W}, 21$ out. 1979 (bot., fl.), S.A. Mori 12861 (CEPEC); Ituberá, $13^{\circ} 43^{\prime} \mathrm{S}, 39^{\circ} 08^{\prime} \mathrm{W}, 5$ fev. 1983 (bot., fl.), A.M. Carvalho 
et al. 1463 (CEPEC); Jussari, 15²10'S, 39 35'W, 18 fev. 1998 (est.), J.G. Jardim et al. 1560 (CEPEC); Maraú, 1356'35"S, 3856'50"W, 15 ago. 1999 (fr.), J.G. Jardim et al. 2253 (CEPEC, SP); Pindobaçu, 1044'S, 40²1'W, abr. 1994 (fr.), M. Sobral \& W. Ganev 7634 (HUEFS); Porto Seguro, 16 $26^{\circ} \mathrm{S}, 39^{\circ} 03^{\prime} \mathrm{W}, 12$ out. 2006 (est.), L.P. Colman \& G.M. Carvalho 26 (ALCB); Rio

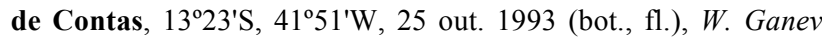
2350 (HUEFS); Santa Cruz Cabrália, $16^{\circ} 23^{\prime} \mathrm{S}, 39^{\circ} 08^{\prime} \mathrm{W}, 7$ jan. 1989 (fl.), F.S. Santos 924 (CEPEC, HUEFS, MBM); Saúde, $10^{\circ} 56^{\prime} \mathrm{S}, 40^{\circ} 25^{\prime} \mathrm{W}, 23$ fev. 1993 (bot., f1.), A.M. Amorim et al. 1051 (CEPEC, MBM); Una, 1509'S, 3905'W, 10 nov. 1993 (fl., fr.), A.M. Amorim et al. 1441 (CEPEC, MBM); Uruçuca, 14²5'S, 3901'W, 11 set. 1991 (est.), A.M. Carvalho et al. 3565 (CEPEC, $\mathrm{SP})$.

Heteropterys coleoptera é caracterizada pelo estilete anterior maior que os posteriores e samarídeos com álulas laterais conspícuas no núcleo seminífero. Apresenta grande variabilidade morfológica, principalmente na forma e dimensões da lâmina foliar e samarídeos (e.g., Amorim 1441, 4063). Assemelha-se morfologicamente a $H$. chrysophylla (ver comentário naquela espécie). Pertence à série Metallophyllis e não consta na lista de espécies ameaçadas da flora brasileira (Amorim et al. 2013).

14. Heteropterys conformis W.R.Anderson, Contr. Univ. Michigan Herb. 15: 127. 1982.

Figura 4; Anderson (1982: fig. 13A-F).

Liana, 0,5-2 $\mathrm{m}$ alt. Folhas cartáceas; pecíolo 10$20 \mathrm{~mm}$ compr., seríceo a glabrescente, base biglandulosa; lâmina 4,6-16,4 × 2-8 cm, elíptica, oblonga, oboval ou lanceolada, base aguda, obtusa ou cuneada, ápice agudo, obtuso, arredondado, raro emarginado ou acuminado, margem revoluta; ambas as faces glabras; a abaxial com 4 ou mais glândulas inconspícuas ou eglandulosa. Umbelas 2-6-floras; brácteas 3-3,3 mm compr.; bractéolas 0,5-0,9 $\mathrm{mm}$ compr., ovais; pedicelos 4,5-6,5 mm compr., sésseis. Sépalas 1,5-2 × 0,9-1,3 mm, ápice plano, seríceocastanho-claras; as laterais biglandulosas e a anterior eglandulosa, ou todas eglandulosas. Pétalas amarelas, membranáceas, margem erosa; as laterais reflexas, limbo $2,4-2,7 \times 1,9-2,2 \mathrm{~mm}$; a posterior ereta a eretopatente, limbo 1,8-2,2 $\times 1,5-1,9 \mathrm{~mm}$. Estames desiguais; filetes glabros, 1,5-2,5 mm compr.; anteras glabras, eretas. Ovário seríceo; estiletes 2,1-2,6 mm compr., divergentes distalmente, o anterior reto e maior que os posteriores, os posteriores curvilíneos e arqueados na base, glabros, ápice dorsalmente obtuso; estigmas laterais, voltados para o centro da flor. Samarídeo [não visto].

Distribuição restrita à Floresta Atlântica da Bahia (Amorim 2003a, 2014). H8, I8: em florestas estacionais semideciduais, a cerca de 180 m s.n.m. Coletada com flores em janeiro e fevereiro.

Material selecionado - Itaju do Colônia, $15^{\circ} 08^{\prime} \mathrm{S}, 39^{\circ} 43^{\prime} \mathrm{W}, 23$ jan. 1969 (bot., fl.), T.S. Santos 346 (holótipo CEPEC, isótipo MICH foto); ib., 1509'12"S, 39³9'39"W, 3 jan. 2001 (bot., fl.), A.M. Amorim et al. 3583 (CEPEC, MICH foto).

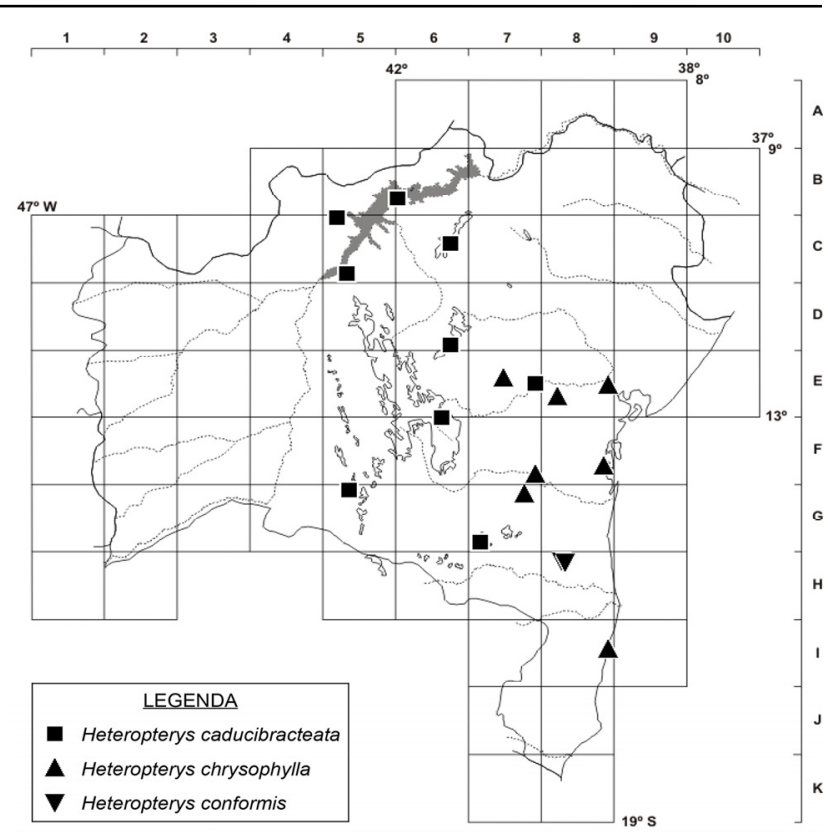

Figura 4. Mapa de distribuição de Heteropterys caducibracteata, H. chrysophylla e $H$. conformis no estado da Bahia.

Heteropterys conformis é caracterizada pela lâmina foliar com ambas as faces glabras, em geral com glândulas inconspícuas na face abaxial e pétalas laterais reflexas, mas pode ser confundida com $H$. catingarum (ver comentário naquela espécie). Existem dúvidas em relação às raras coleções de $H$. conformis em Minas Gerais e no Rio de Janeiro. Amorim (2003a) revelou que a coleção Glaziou 13608 é o tipo de $H$. crenulata f. eglandulosa Nied. (= H. conformis) e a coleção Glaziou 12491 traz na etiqueta dos herbários G e P a localidade "Biribiry", situada nos arredores de Diamantina, Minas Gerais, mas "environs de Rio de Janeiro" na duplicata depositada em K. Com base nessas evidências, aliado ao fato de que nenhuma outra amostra de $H$. conformis foi documentada em Minas Gerais ou no Rio de Janeiro, Amorim (2003a) concluiu que a espécie possui distribuição restrita ao sul da Bahia. Heteropterys conformis pertence à subseção Aptychia e é uma espécie criticamente em perigo (Amorim et al. 2013).

15. Heteropterys cordifolia Moric. ex A.Juss., Ann. Sci. Nat. Bot. II, 13: 278. 1840.

Figura 6; Moricand (1840).

Liana, 2-25 m alt. Folhas cartáceas a coriáceas; pecíolo 2-7 $\mathrm{mm}$ compr., tomentoso a glabrescente, base biglandulosa; lâmina 7-23,2 × 3-13,5 cm, oval, oboval, oblanceolada a lanceolada, base obtusa, arredondada, cordada a obtuso-auriculada, ápice agudo, obtuso ou acuminado, margem revoluta; ambas as faces tomentosas a glabrescentes; a abaxial com quatro ou mais glândulas. Umbelas 4-6-floras; brácteas 1,54,5 mm compr.; bractéolas 0,9-1,1 mm compr., ovais; pedicelos 5-12 mm compr., sésseis. Sépalas 1,9-2,3 $\times$ 1,5-1,7 mm, ápice plano, tomentoso-ferrugíneas; as laterais biglandulosas e a anterior eglandulosa, raro 


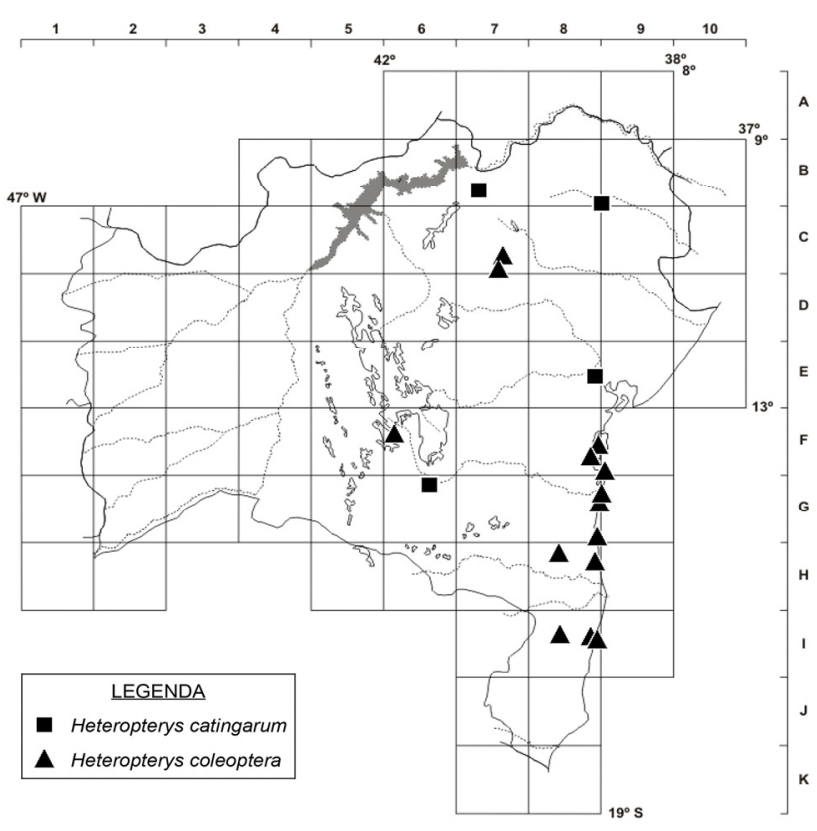

Figura 5. Mapa de distribuição de Heteropterys catingarum e H. coleoptera no estado da Bahia.

apenas as latero-posteriores com uma glândula ou todas eglandulosas. Pétalas amarelas, crassas; as laterais patentes a sub-reflexas, limbo 4,2-4,7 × 3,5$4,5 \mathrm{~mm}$, margem inteira a erosa; a posterior ereta a patente, limbo 4,5-5,5 × 3,4-4,7 mm, margem erosa. Estames iguais; filetes glabros, 1,8-3 mm compr.; anteras glabras, eretas. Ovário tomentoso; estiletes 2,6-3,7 mm compr., retos, paralelos entre si, não arqueados na base, glabros, ápice dorsalmente arredondado; estigmas laterais, voltados para a pétala posterior. Samarídeos tomentosos; ala dorsal 35-55 mm compr.; núcleo seminífero liso.

Distribuição restrita à Floresta Atlântica da Bahia (Amorim 2003a, 2014). F8, G8/9, H8, H9, I8: em florestas ombrófilas montanas, submontanas e de terras baixas, entre 20 e 350 m s.n.m. Coletada com flores de março a julho e com frutos de junho a agosto e em novembro.

Material selecionado - Belmonte, $15^{\circ} 51^{\prime} \mathrm{S}, 38^{\circ} 52^{\prime} \mathrm{W}, 3$ nov. 2001 (fr.), J.G. Jardim et al. 3952 (CEPEC); Camacan, 15²3'30"S, 39³3'55"W, 29 out. 2004 (est.), A.M. Amorim et al. 4386 (CEPEC); Camamu, 14 $00^{\prime}$ S, 39 $13^{\prime} \mathrm{W}, 15$ jun. 1979 (bot., fl.), L.A.M. Silva et al. 498 (CEPEC); Canavieiras, 15²0'S, 3856'W, 21 jul. 1981 (fl.), L.A.Mattos-Silva et al. 1320 (CEPEC); Itacaré, 14²16'S, 3859'W, 14 jul. 1971 (bot., fl.), T.S. Santos et al. 1763 (CEPEC); Nilo Peçanha, 133' S, 3909'W, 11 jun. 1973 (bot., fl.), T.S. Santos et al. 2670 (CEPEC); Porto Seguro, 16²6'S, 3903'W, 23 mar. 1968 (bot., fl.), S.G. Vinha et al. 111 (CEPEC); Potiraguá, 15²2'12"S, 39³4'31"W, 2 jun. 2004 (bot., fl.), P. Fiaschi et al. 2276 (CEPEC); Santa Cruz Cabrália, $16^{\circ} 16^{\prime} \mathrm{S}, 39^{\circ} 01^{\prime} \mathrm{W}, 2$ jul. 1978 (bot., fl.), S.A. Mori 10241 (CEPEC); Santa Luzia, 15²5'S, 39²0'W, 10 ago. 1999 (fr.), A.M. Amorim et al. 3087 (CEPEC, MBM, SP); Uruçuca, $15^{\circ} 25^{\prime} \mathrm{S}, 39^{\circ} 01^{\prime} \mathrm{W}$, 3 out. 2000 (est.), W.W. Thomas 12209 (CEPEC).

Heteropterys cordifolia é caracterizada pela base da lâmina foliar cordada a obtuso-auriculada encobrindo o pecíolo, ambas as faces com indumento tomentoso a glabrescente e samarídeos com ala dorsal $35-55 \mathrm{~mm}$ compr. Assemelha-se a $H$. jardimii pelo tipo de indumento da face abaxial da lâmina foliar e pela consistência e posição das pétalas, mas podem ser diferenciadas pela forma do ápice dos estiletes e posição dos estigmas. Segundo Amorim (2003a), em populações dos tabuleiros costeiros e em espécimes de áreas mais úmidas e sombreadas, os tricomas são precocemente decíduos, com a lâmina nitidamente glabrescente em ambas as faces. Outros caracteres como a dimensão, consistência e forma da lâmina foliar, assim como sua margem, são muito variáveis num mesmo indivíduo, em indivíduos de uma mesma população ou em indivíduos de diferentes populações (Amorim 2003a). Pertence à subseção Aptychia e não consta na lista de espécies ameaçadas da flora brasileira (Amorim et al. 2013).

16. Heteropterys coriacea A.Juss., Ann. Sci. Nat., Bot. II, 13: 277.1840.

Figuras 7 e 18F-J.

Arbusto ou arvoreta, 1-4 m alt. Folhas coriáceas; pecíolo 1-6,2 mm compr.; tomentoso a glabrescente, eglanduloso; lâmina 2,4-7 × 1,4-3,4 cm, orbicular a cordada, base arredondada a cordada, ápice agudo, arredondado a cuspidado, margem revoluta; ambas as faces glabras; a abaxial com 2-4 glândulas intramarginais. Corimbos 3-6-floros; brácteas 1,8-2,3 $\mathrm{mm}$ compr.; bractéolas 1,6-2,2 mm compr., ovais; pedicelos 3,4-9,6 mm compr., pedunculados. Sépalas $3,7-4,2 \times 2-2,5 \mathrm{~mm}$, ápice revoluto, tomentosoferrugíneas; as laterais biglandulosas, a anterior eglandulosa. Pétalas amarelas, membranáceas, margem erosa; as laterais sub-reflexas a reflexas, limbo 4-5 × 3,8-4,7 mm; a posterior ereta a ereto-patente, limbo 3,5-3,9 × 3,6-4 mm. Estames iguais; filetes glabros, 1-1,7 mm compr.; anteras pilosas, eretas. Ovário seríceo; estiletes 2,1-2,5 $\mathrm{mm}$ compr., retos, divergentes distalmente, não arqueados na base, glabros, ápice dorsalmente apiculado-uncinado; estigmas laterais, o anterior voltado para o centro da flor, os posteriores para as pétalas latero-posteriores. Samarídeos seríceos; ala dorsal 12,5-35,6 mm compr.; núcleo seminífero com nervuras conspícuas na lateral.

Ocorre na Bahia, Goiás, Mato Grosso, Minas Gerais e São Paulo (Amorim 2014). E2, E3, E6, F3, G3, G5: em campos rupestres e cerrados, entre 450 e 1100 m s.n.m. Coletada com flores em março, de maio a setembro e em novembro e com frutos de agosto a novembro.

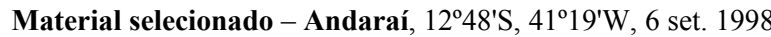
(fl., fr.), A.M. Amorim et al. 2489 (CEPEC, SP); Barreiras, $12^{\circ} 09^{\prime} \mathrm{S}$,

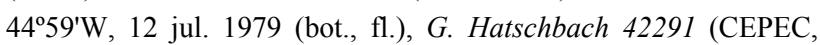
MBM); Correntina, $13^{\circ} 25^{\prime} \mathrm{S}, 4^{\circ} 44^{\prime} \mathrm{W}, 10$ ago. 1996 (fl., fr.), J.G. Jardim et al. 945 (CEPEC, HUEFS, MBM); Feira da Mata, $14^{\circ} 13^{\prime} 54^{\prime \prime S}, 44^{\circ} 12^{\prime} 45^{\prime \prime W}, 8$ maio 2007 (fl.), M.L. Guedes et al. 13390 (ALCB); Licínio de Almeida, 14²44'44"S, 42³4'23"W, 20 jul. 2012 (fl.), N. Roque et al. 3689 (ALCB); Mucugê, 1300'S, $41^{\circ} 22^{\prime} \mathrm{W}, 9$ mar. 2004 (fl.), L. Maliarenko s.n. (ALCB 67848); 
Palmeiras, $12^{\circ} 31^{\prime} \mathrm{S}, 41^{\circ} 33^{\prime} \mathrm{W}, 5$ set. 1998 (bot., fl.), A.M. Amorim et

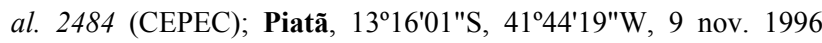
(fr.), H.P. Bautista \& D.J.N. Hind 4174 (ALCB, CEPEC, HUEFS); Riachão das Neves, $12^{\circ} 44^{\prime} 31^{\prime \prime} \mathrm{S}, 4^{\circ} 21^{\prime} 13^{\prime \prime} \mathrm{W}, 13$ mar. 2010 (est.), K. Yoshida-Arns et al. s. n. (HUEFS 172623).

Heteropterys coriacea é caracterizada pela lâmina foliar em geral orbicular, com base arredondada a cordada, face abaxial com 2-4 glândulas intramarginais, anteras pilosas, o estilete anterior com o estigma voltado para o centro da flor e os posteriores para as pétalas latero-posteriores. Assemelha-se a $H$. procoriacea Nied. (espécie de Minas Gerais e Mato Grosso do Sul) (Amorim 2014) por ambas apresentarem lâmina foliar com base geralmente cordada, mas diferem pela forma da lâmina foliar e pilosidade dos conectivos (lâmina oblonga a oval e conectivos glabros em $H$. procoriacea). Heteropterys coriacea pertence ao subgênero Parabanisteria e não consta na lista de espécies ameaçadas da flora brasileira (Amorim et al. 2013).

\section{Heteropterys dumetorum (Griseb.) Nied.,} Pflanzenr. IV, 141: 336. 1928.

Figuras 6 e 19G-K.

Arbusto, 1,5-7 $\mathrm{m}$ alt. Folhas membranáceas a papiráceas; pecíolo 1,6-7,6 $\mathrm{mm}$ compr., seríceo a glabrescente, eglanduloso; lâmina 2-6,7 × 1,2-4,5 cm, oval, base cuneada a subcordada, ápice agudo ou arredondado, margem revoluta; ambas as faces seríceas a glabrescentes; a abaxial com 2-4 glândulas estipitadas próximo à base. Umbelas 4-floras; brácteas 1,2-1,9 mm compr.; bractéolas 1,2-1,6 mm compr., ovais; pedicelos 3,8-4,7 mm compr., pedunculados. Sépalas 1,5-1,9 × 0,9-1,2 $\mathrm{mm}$, ápice plano, seríceoesverdeadas; as laterais biglandulosas e a anterior eglandulosa, às vezes as latero-posteriores triglandulosas. Pétalas amarelas, membranáceas, margem erosa; as laterais patentes, limbo 4,6-5,2 $\times$ 3,6-4 mm; a posterior patente, limbo 3,3-3,8 $\times 3-3,6$ mm. Estames desiguais; filetes glabros, 1,2-2,1 mm compr.; anteras glabras, eretas a ressupinadas. Ovário seríceo; estiletes 1,6-2,9 $\mathrm{mm}$ compr., divergentes distalmente, o anterior reto, os posteriores curvilíneos e inclinados para a pétala posterior, glabros, o anterior com ápice dorsalmente truncado-uncinado e os posteriores apiculado-uncinados; estigmas laterais, voltados para o centro da flor. Samarídeos seríceos; ala dorsal 12,2-16,3 mm compr.; núcleo seminífero com nervuras laterais conspícuas.

Ocorre na Bahia, Distrito Federal, Goiás, Mato Grosso, Paraná e São Paulo (Amorim 2014). E2/3, G5: em cerrados, entre 450 e 980 m s.n.m. Coletada com flores em abril e setembro e com frutos em abril, setembro e dezembro.

Material selecionado - Barreiras, $12^{\circ} 09^{\prime} \mathrm{S}, 44^{\circ} 59^{\prime} \mathrm{W}, 14 \mathrm{dez}$. 2008 (fr.), C. Pessoa 1 (CEPEC); ib, 12 abr. 2008 (fl., fr.), J.M. Santos et al. 13 (CEPEC); Licínio de Almeida, 1444'29"S, 42³4'17"W, 17 set. 2011 (fl., fr.), N. Roque et al. 3354 (ALCB).
Material adicional examinado - BRASIL. GOIÁS: Jataí, $17^{\circ} 18^{\prime} \mathrm{S}, 51^{\circ} 48^{\prime} \mathrm{W}, 23$ out. 1964 (fr.), H.S. Irwin 7261 (NY foto); Caiapônia, 16 $57^{\prime} 36^{\prime \prime S}, 51^{\circ} 48^{\prime} 36^{\prime \prime W}, 24$ out. 1964 (fl.), G.T. Prance et al. 59610 (NY foto).

Heteropterys dumetorum é reconhecida pelo pecíolo seríceo a glabrescente, eglanduloso, face abaxial da lâmina foliar com 2-4 glândulas estipitadas próximo à base, inflorescência em ramos áfilos devido a deciduidade precoce das folhas, pétalas membranáceas e estiletes com a forma do ápice misto. Em Heteropterys dumetorum, também se observou a presença de sépalas latero-posteriores triglandulosas, situação incomum na família. Assemelha-se a $H$. syringifolia pela forma das glândulas da lâmina foliar e pilosidade dos estiletes, diferindo pelo indumento do pecíolo, glândulas nas sépalas latero-posteriores e forma do ápice dos estiletes. Pertence à série Xanthopetalis e não consta na lista de espécies ameaçadas da flora brasileira (Amorim et al. 2013).

18. Heteropterys eglandulosa A.Juss., Fl. Bras. Merid. 3: 27.1833 .

Figuras $6,18 \mathrm{~K}-\mathrm{O}$ e $24 \mathrm{C}$, D.

Arbusto, ca. $4 \mathrm{~m}$ alt. Folhas coriáceas; pecíolo 2,4-8,9 mm compr., seríceo a glabrescente, eglanduloso; lâmina 3,2-10,7 × 1,5-5,6 cm, elíptica a oval, base cuneada a arredondada, ápice acuminado, margem revoluta; ambas as faces glabras; a abaxial com 8 ou mais glândulas marginais. Corimbos 4-8floros; brácteas 1,5-1,9 mm compr.; bractéolas 1,7-2,1 mm compr., ovais; pedicelos 2-4,6 mm compr., pedunculados. Sépalas $3,1-3,5 \times 1,2-1,6 \mathrm{~mm}$, ápice revoluto, tomentoso-ferrugíneas; todas eglandulosas, raro as laterais biglandulosas e a anterior eglandulosa ou com apenas 1 glândula. Pétalas amarelas, membranáceas, margem erosa; as laterais sub-reflexas a reflexas, limbo 2,8-3,5 × 2,4-3,1 $\mathrm{mm}$; a posterior ereta a ereto-patente, limbo 2,4-2,9 × 1,8-2,2 mm. Estames desiguais; filetes glabros, 0,8-1,4 $\mathrm{mm}$ compr.; anteras glabras, eretas a ressupinadas. Ovário seríceo; estiletes 1,9-2,3 mm compr., retos, divergentes distalmente, não arqueados na base, glabros, ápice dorsalmente apiculado-uncinado; estigmas laterais, voltados para a pétala posterior. Samarídeos seríceos; ala dorsal 22,3-26,2 mm compr.; núcleo seminífero com nervuras laterais conspícuas.

Ocorre na Bahia, Distrito Federal, Goias, Minas Gerais, Piauí e São Paulo (Amorim 2014). D5, E6, E8, E9, F2, F3, F6, G5: em campos rupestres e cerrados, entre 300 e 740 m s.n.m. Coletada com flores de janeiro a abril, outubro e novembro e com frutos de janeiro a abril e de outubro a dezembro.

Material selecionado - Abaíra, 131'59"S, 41³9'00"W, 14 out. 2006 (f1.), D. Rigueira et al. s.n. (ALCB 74634); Alagoinhas, $12^{\circ} 11^{\prime} 08^{\prime \prime S}, 38^{\circ} 25^{\prime} 21^{\prime \prime W}, 29$ jan. 2004 (fl., fr.), N.G. Jesus et al.

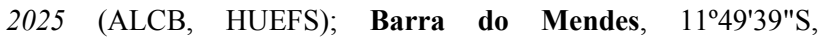
42 $08^{\prime} 11 " \mathrm{~W}, 25$ out. 2009 (fl., fr.), E. Melo et al. 6847 (ALCB, HUEFS); Correntina, $13^{\circ} 15^{\prime} \mathrm{S}, 45^{\circ} 45^{\prime} \mathrm{W}, 7$ nov. 1990 (fl.), A.V. Resende et al. 39 (CEPEC); Itatim, 12 ${ }^{\circ} 43^{\prime} \mathrm{S}, 39^{\circ} 42^{\prime} \mathrm{W}, 25$ fev. 1996 


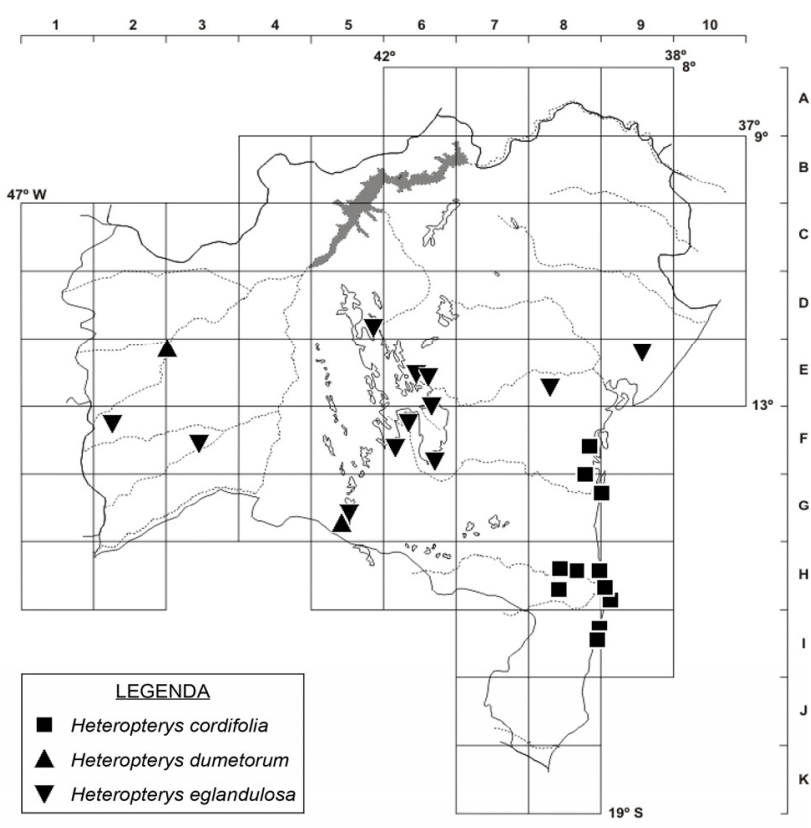

Figura 6. Mapa de distribuição de Heteropterys cordifolia, H. dumetorum e H. eglandulosa no estado da Bahia.

(fl., fr.), E. Melo et al. 1500 (CEPEC, HUEFS); Ituaçu, 1348'S, 411' W, 31 mar. 1988 (bot., fl.), E. Gouvêia s.n. (ALCB 20634);

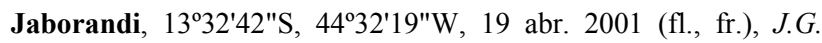
Jardim et al. 3705 (CEPEC, HUEFS, UESC); Lençóis, 12³3'S, 412' W, 30 abr. 1999 (fr.), A.M. Amorim et al. 3062 (CEPEC); Mucugê, $12^{\circ} 59^{\prime} 18^{\prime \prime} \mathrm{S}, 41^{\circ} 20^{\prime} 27^{\prime \prime W}, 25$ jan. 2003 (fr.), N. Roque et

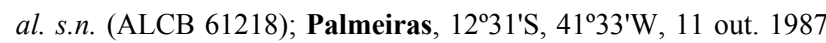
(fl.), M.L. Guedes et al. 1474 (ALCB, CEPEC); Rio de Contas, 13³5'47"S, 4149'36"W, 14 nov. 1996 (fr.), N. Hind et al. PCD 4263 (ALCB, CEPEC, HUEFS).

Heteropterys eglandulosa é caracterizada pelo pecíolo seríceo a glabrescente, lâmina foliar elíptica a oval, ambas as faces glabras, com oito ou mais glândulas marginais e estiletes não arqueados na base. Assemelha-se a $H$. nervosa, devido à consistência das folhas, indumento da lâmina foliar, forma das bractéolas e a ala dorsal dos samarídeos, com a região basal estreita e a apical alargada. Contudo, são distinguidas pelo indumento do pecíolo, forma e dimensões da lâmina foliar, posição das pétalas laterais e dos estiletes posteriores. Além da semelhança morfológica, ambas apresentam distribuição geográfica semelhante. Heteropterys eglandulosa pertence ao subgênero Parabanisteria e não consta na lista de espécies ameaçadas da flora brasileira (Amorim et al. 2013).

19. Heteropterys escalloniifolia A.Juss., Ann. Sci. Nat., Bot. II, 13: 276. 1840.

Figuras 8, 20A-G.

Arbusto, 1,5-2 m alt. Folhas coriáceas; pecíolo 1,5-3,5 $\mathrm{mm}$ compr., tomentoso a glabrescente, eglanduloso; lâmina 1,8-5 × 0,7-2,1 cm, oblanceolada a elíptica, base cuneada, raro obtusa, ápice obtusoacuminado, margem revoluta; face adaxial glabra; a abaxial serícea a glabrescente, com 4-8 glândulas intramarginais ou eglandulosa. Corimbos 2-10-floros; brácteas 2,3-2,9 mm compr.; bractéolas 2-2,3 $\mathrm{mm}$ compr., elípticas; pedicelos 2,7-4,7 mm compr., pedunculados. Sépalas 3,3-3,5 × 1,6-2,1 mm, ápice revoluto, seríceo-ferrugíneas; as laterais biglandulosas e a anterior eglandulosa, ou todas eglandulosas. Pétalas amarelas, membranáceas, margem erosa; as laterais sub-reflexas, limbo 5-6 × 4,6-5,3 mm; a posterior ereta, limbo 5-5,3 × 4,6-4,9 mm. Estames iguais; filetes glabros, 1,8-2,6 mm compr.; anteras glabras, raro ápice piloso, eretas. Ovário tomentoso; estiletes 2,3-2,5 $\mathrm{mm}$ compr., retos, divergentes distalmente, não arqueados na base, o anterior maior que os posteriores, glabros, ápice dorsalmente arredondado, apiculado ou obtuso-apiculado; estigmas laterais, voltados para a pétala posterior. Samarídeos tomentosos; ala dorsal 15,3-23,2 mm compr.; núcleo seminífero com nervuras laterais inconspícuas.

Ocorre na Bahia e em Minas Gerais (Amorim 2014). E6, F5, F6, G3: em campos rupestres, com uma população detectada no cerrado de Cocos, entre 530 e 1600 m s.n.m. Coletada com flores em janeiro, agosto e setembro e com frutos em março e agosto.

Material selecionado - Abaíra, $13^{\circ} 17^{\prime} \mathrm{S}, 4^{\circ}{ }^{\circ} 54^{\prime} \mathrm{W}, 12$ jan. 1994 (bot., fl.), W. Ganev 2784 (HUEFS, SP); Cocos, $14^{\circ} 11^{\prime} \mathrm{S}, 4^{\circ} 32^{\prime} \mathrm{W}$, 16 mar. 1972 (fr.), W.R. Anderson et al. 37073 (NY foto); Mucugê, $13^{\circ} 00^{\prime} \mathrm{S}, 41^{\circ} 22^{\prime} \mathrm{W}, 16$ set. 1984 (bot., fl.), G. Hatschbach 48309 (CEPEC, MBM); Palmeiras, $12^{\circ} 25^{\prime} \mathrm{S}, 41^{\circ} 27^{\prime} \mathrm{W}, 5$ set. 2006 (fl.), P.D. Carvalho et al. 323 (HUEFS); Piatã, $13^{\circ} 07$ 'S, 41 ${ }^{\circ} 54^{\prime} \mathrm{W}, 22$ ago. 1992 (fl.), W. Ganev 946 (HUEFS, SP); Rio de Contas, $13^{\circ} 36^{\prime} \mathrm{S}, 41^{\circ} 48^{\prime} \mathrm{W}, 6$ set. 2003 (fl.), R.M. Harley \& A.M. Giulietti 54661 (CEPEC, HUEFS); Rio do Pires, $13^{\circ} 46^{\prime} \mathrm{S}, 42^{\circ} 22^{\prime} \mathrm{W}, 5$ ago. 1993 (fl.), W. Ganev 2012 (HUEFS, SP).

Heteropterys escalloniifolia é caracterizada pelo indumento do pecíolo tomentoso a glabrescente, folhas geralmente apressas aos ramos, lâmina foliar 1,8-5 cm compr., oblanceolada a elíptica, com face abaxial serícea a glabrescente, e estilete anterior maior que os posteriores. Assemelha-se a $H$. byrsonimifolia (ver comentário naquela espécie), pertence ao subgênero Parabanisteria e não consta na lista de espécies ameaçadas da flora brasileira (Amorim et al. 2013).

20. Heteropterys grandiflora A.Juss., Arch. Mus. Hist. Nat. Paris 3: 461. 1843.

Figuras 9, 20H-L e 23A.

Arbusto ou liana, 2-5 m alt. Folhas cartáceas a coriáceas; pecíolo 3,7-8,4 $\mathrm{mm}$ compr., glabro, eglanduloso; lâmina 2,5-9,6 × 1,2-3,6 cm, oblonga a oboval, raro elíptica a oval, base cuneada, ápice agudo ou acuminado, margem ondulada; ambas as faces glabras; a abaxial com 8 ou mais glândulas marginais. Corimbos 2-10-floros; brácteas 1,9-2,3 mm compr.; bractéolas 1,8-2,2 mm compr., ovais; pedicelos 2,3-4,2 $\mathrm{mm}$ compr., pedunculados. Sépalas 3-3,9 × 1,5-1,9 $\mathrm{mm}$, ápice revoluto, tomentoso-ferrugíneas; todas eglandulosas, raro laterais biglandulosas e anterior eglandulosa. Pétalas amarelas, membranáceas, margem erosa; as laterais sub-reflexas, limbo 5,6-7,1 × 4,5-5,4 $\mathrm{mm}$; a posterior ereta, limbo $5,5-5,7 \times 4,5-4,7 \mathrm{~mm}$. 
Estames iguais; filetes glabros, 1,6-2,6 mm compr.; anteras pilosas no ápice, raro glabras, eretas. Ovário seríceo; estiletes 2,1-2,4 mm compr., retos, divergentes distalmente, os posteriores arqueados na base, glabros, ápice dorsalmente apiculado ou obtuso-apiculado; estigmas laterais, voltados para a pétala posterior. Samarídeos seríceos; ala dorsal 17-35 mm compr.; núcleo seminífero com nervuras laterais inconspícuas.

Distribuição restrita à Bahia (Amorim 2014). B8/9, C7, D6/7, D9, E2, E5, E6, E8, F4, F5, F7, G7, G8: em caatingas e campos rupestres, entre 400 e 900 m s.n.m, com uma população detectada no cerrado de Carinhanha e outra em floresta ombrófila de Itaju do Colônia. Coletada com flores de janeiro a março e de setembro a novembro e com frutos em janeiro, abril, outubro e novembro.

Material selecionado - Andaraí, $12^{\circ} 51^{\prime} \mathrm{S}, 41^{\circ} 19^{\prime} \mathrm{W}, 13 \mathrm{fev}$ 1977 (bot., fl.), R.M. Harley et al. 18613 (CEPEC, RB); Barreiras, $12^{\circ} 9^{\prime} 10^{\prime \prime S}, 45^{\circ} 06^{\prime} 30^{\prime \prime W}, 6$ set. 2005 (fl.), E. Melo et al. 4039 (HUEFS); Caetité, 1350'27"S, 42 $16^{\prime} 21^{\prime \prime} \mathrm{W}, 26$ set. 2009 (bot., fl.), J.L. Paixão et al. 1580 (HUESC); Campo Formoso, $10^{\circ} 29^{\prime} \mathrm{S}$, 40² $28^{\prime} \mathrm{W}, 7$ mar. 1976 (bot., fl.), W.R. Anderson 11746 (MBM); Canudos, 09 $56^{\circ}$ 'S, 38 $58^{\circ} \mathrm{W}, 22$ out. 2004 (fl.), F.H.M. Silva \& L.C.L. Lima 515 (HUEFS); Carinhanha, $14^{\circ} 00^{\prime} \mathrm{S}, 43^{\circ} 43^{\prime} \mathrm{W}, 29 \mathrm{dez}$ 2007 (est.), M.L.S. Guedes 14106 (ALCB, HUEFS); Iaçu, 1245'18"S, 3953'57"W, 28 set. 1997 (fl.), E. Melo et al. 2272 (HUEFS); Ibipitanga, 12²4'07"S, 42³0'33"W, 11 out. 2007 (bot., fl.), A.A. Conceição et al. 2559 (HUEFS); Itaju do Colônia, $14^{\circ} 55^{\prime} 54^{\prime \prime S}, 39^{\circ} 29^{\prime} 01^{\prime \prime W}, 28$ out. 2004 (bot., fl.), A.M. Amorim et al. 4346 (CEPEC, HUEFS, SP); Jacobina, $11^{\circ} 14^{\prime} 35^{\prime \prime S}, 40^{\circ} 43^{\prime} 48^{\prime \prime} \mathrm{W}, 31$ mar. 1996 (bot., fl.), A.M. Giulietti et al. PCD 2695 (ALCB, HUEFS, K foto); Jaguarari, $10^{\circ} 02^{\prime} \mathrm{S}, 40^{\circ} 13^{\prime} \mathrm{W}, 28$ jul. 2005 (est.), A.A. Conceição 1438 (HUEFS); Jequié, 1351'S, 404'59"W, 19 out. 1997 (fl.), M.L. Guedes et al. 5393 (ALCB); Maracás, 13²6'S, $40^{\circ} 25^{\prime} \mathrm{W}, 17$ nov. 1978 (fl., fr.), S.A. Mori et al. 11088 (CEPEC, RB); Milagres, $12^{\circ} 45^{\prime} 18^{\prime \prime S}, 39^{\circ} 53^{\prime} 57^{\prime \prime} \mathrm{W}, 26$ out. 1997 (fl., fr.), $F$ França et al. 2435 (CEPEC, HUEFS); Morro do Chapéu, 11³7'S, $41^{\circ} 00^{\prime} \mathrm{W}, 21$ out. 1980 (fr.), R. Orlandi 324 (RB 314693); Rio de Contas, 134' $10^{\prime \prime}$ S, 42 $12^{\circ} 18^{\prime \prime W}, 22$ set. 2009 (fl.), I.S. Abreu 43 (ALCB); Tucano, $11^{\circ} 07^{\prime} 22^{\prime \prime S}, 38^{\circ} 46^{\prime} 23^{\prime \prime} \mathrm{W}, 17$ abr. 2008 (fr.), L.P. Queiroz et al. 13680 (HUEFS); Vitória da Conquista, 14 $51^{\circ} \mathrm{S}$, 4050'W, 29 nov. 1986 (fl., fr.), A. Chautems et al. 197 (CEPEC).

Heteropterys grandiflora é caracterizada pela lâmina foliar com margem ondulada, pedicelos 2,3-4,2 $\mathrm{mm}$ compr., pétalas com margens denticuladas, estiletes posteriores arqueados na base, ápice dos estiletes dorsalmente arredondados a obtusos e samarídeos com ala dorsal de 17-35 mm compr. É semelhante morfologicamente a $H$. macradena por apresentar lâmina foliar com margem ondulada. Entretanto, distingue-se dela pela forma da lâmina foliar geralmente oblonga a oboval, conectivos com a região basal escura (vermelha) e apical clara (amarela), além da ala dorsal do samarídeos com disposição perpendicular (vs. lâmina geralmente elíptica a oval, conectivos uniformemente escuros, vermelhos, e ala dorsal com disposição abruptamente perpendicular em H. macradena). Pertence ao subgênero Parabanisteria e não consta na lista de espécies ameaçadas da flora brasileira (Amorim et al. 2013).
21. Heteropterys imperata Amorim, Brittonia 55: 132. 2003.

Figura 10; Amorim (2003b: fig. 4).

Liana, 3-10 m alt. Folhas cartáceas a coriáceas; pecíolo 10-22 mm compr., seríceo a glabrescente, base biglandulosa; lâmina 7,3-20 × 5,5-13 cm, elíptica, oblonga, oval a orbicular, base cuneada, arredondada ou cordada, ápice arredondado, agudo ou retuso, margem revoluta; face adaxial glabra; a abaxial serícea, com 6 ou mais glândulas marginais. Umbelas 4-6floras; brácteas 1,7-4,3 mm compr.; bractéolas 0,8-0,9 $\mathrm{mm}$ compr., ovais; pedicelos 8,5-10 mm compr., sésseis. Sépalas $1,8-2,5 \times 1,8-2,4 \mathrm{~mm}$, ápice plano, seríceo-ferrugíneas; as laterais biglandulosas e a anterior eglandulosa, ou todas eglandulosas. Pétalas amarelas, crassas, carenada; as laterais patentes, limbo 4,5-5,5 × 4,5-5 mm, margem inteira a erosa; a posterior ereta a ereto-patente, limbo 4-4,5 × 3,7-4,2 $\mathrm{mm}$, margem glanduloso-espessada. Estames desiguais; filetes glabros, 3-4,5 mm compr.; anteras glabras. Ovário seríceo; estiletes 4-4,5 mm compr., retos, paralelos entre si, os posteriores arqueados na base, glabros, ápice dorsalmente apiculado; estigmas laterais, voltados para o centro da flor. Samarídeos seríceos a glabrescentes; ala dorsal 45-48 mm compr.; núcleo seminífero liso.

Distribuição restrita à Floresta Atlântica da Bahia (Amorim 2003a,b). D10, E6, E8, E9/10, F8, G8/9, H8/9, I8: em florestas ombrófilas montanas, submontanas e de terras baixas, entre 30 e $1080 \mathrm{~m}$ s.n.m., com duas populações detectadas em florestas ombrófilas interioranas, uma no município de Lençóis e outra no de Palmeiras. Coletada com flores de fevereiro a julho e setembro e com frutos de abril a junho e de agosto a novembro.

Material selecionado - Canavieiras, $15^{\circ} 40^{\prime} \mathrm{S}, 38^{\circ} 56^{\prime} \mathrm{W}, 26$ out. 1988 (fr.), L.A. Mattos-Silva et al. 2624 (CEPEC); Conde, $12^{\circ} 01^{\prime} 41^{\prime \prime S}, 37^{\circ} 41^{\prime} 58^{\prime \prime W}, 24$ abr. 1995 (bot., fl.), T. Jost et al. 97 (CEPEC, UESC); Ibirapitanga, 135'ㄱ' $27^{\prime \prime} \mathrm{S}, 39^{\circ} 27^{\prime} 33^{\prime \prime} \mathrm{W}, 12$ maio 2005 (bot., fl.), A.M. Amorim et al. 4922 (CEPEC); Ilhéus, 14²4'S, $39^{\circ} 02^{\prime} \mathrm{W}, 29$ jul. 1993 (bot., fl.), J.G. Jardim et al. 249 (CEPEC, MBM, SP); Itacaré, $14^{\circ} 16^{\prime} \mathrm{S}, 38^{\circ} 59^{\prime} \mathrm{W}, 20$ nov. 1991 (fr.), A.M. Amorim et al. 397 (CEPEC); Itanagra, 12²2'32"S, 37058'51"W, 1 fev. 2009 (bot., fl.), A.R. Prates et al. 291 (ALCB); Ituberá, $13^{\circ} 43^{\prime} \mathrm{S}, 39^{\circ} 08^{\prime} \mathrm{W}, 3$ set. 2001 (fl.), M.L. Guedes et al. 9443 (ALCB,

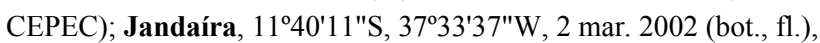
M.L. Guedes \& F.S. Gomes 19380 (ALCB); Lençóis, 12³3'S, $41^{\circ} 23^{\prime} \mathrm{W}, 26$ jan. 2000 (est.), J.G. Jardim et al. 2530 (CEPEC); Maraú, $14^{\circ} 06^{\prime}$ S, 3900'W, 25 ago. 1979 (bot.), S.A. Mori 12757 (CEPEC); Nilo Peçanha, 1335'S, 3906'W, 22 set. 1988 (fl.), L.A. Mattos-Silva et al. 2580 (CEPEC, HUEFS, MBM); Palmeiras, $12^{\circ} 27^{\prime} 20^{\prime \prime} \mathrm{S}, 41^{\circ} 28^{\prime} 15^{\prime \prime} \mathrm{W}, 25$ out. 1994 (fr.), A.M. Carvalho et al. PCD 956 (ALCB, CEPEC, HUEFS); Porto Seguro, 16 26' $39^{\circ} 03^{\prime} \mathrm{W}, 12$ out. 2006 (est.), L.P. Colman \& G.M. Carvalho 31 (ALCB); Santa Cruz Cabrália, 16 $06^{\prime} 34^{\prime \prime} \mathrm{S}, 38^{\circ} 59^{\prime} 33^{\prime \prime} \mathrm{W}, 3$ abr. 2003 (fl., fr.), A.M. Amorim et al. 3696 (CEPEC, MBM, SP); Santa Teresinha, $12^{\circ} 51^{\prime} 10^{\prime \prime S}, 39^{\circ} 28^{\prime} 32^{\prime \prime} \mathrm{W}, 27$ set. 2000 (bot., fl.), L.P. Queiroz et al. 6372 (HUEFS); Una, 15²17'S, 3904'W, 22 jul. 1998 (fl.), L.A. Mattos-Silva et al. 3839 (ALCB, CEPEC, HUEFS, 
UESC); Uruçuca, $14^{\circ} 25^{\prime} \mathrm{S}, 39^{\circ} 01^{\prime} \mathrm{W}, 11-21$ set. 1991 (fl.), $A . M$. Carvalho et al. 3559 (holótipo CEPEC, isótipo HUEFS).

Heteropterys imperata é caracterizada pelo hábito lianescente e robusto, com folhas em geral coriáceas, lâmina foliar 7,3-20 × 5,5-13 cm, pétalas crassas e carenadas, filetes de 3-4,5 mm compr. e estiletes de 4 4,5 mm compr. Assemelha-se a $H$. nordestina pela dimensão do pedicelo, últimas unidades da inflorescência e posição da ala dorsal dos samarídeos, mas diferem nas dimensões das sépalas, pétalas laterais, filetes e estiletes. Um dos aspectos que também auxilia na separação dessas duas espécies é a inflorescência ereta em $H$. imperata (vs. pêndula em $H$. nordestina) (Amorim 2003a). Pertence à subseção Aptychia e não consta na lista de espécies ameaçadas da flora brasileira (Amorim et al. 2013).

22. Heteropterys intermedia (A.Juss.) Griseb., Fl. Bras. 12(1): 62.1858.

Figura 9; Sebastiani \& Mamede (2010: fig. 6).

Liana, 3-12 $\mathrm{m}$ alt. Folhas membranáceas a cartáceas; pecíolo 0,5-2,6 mm compr., glabrescente, eglanduloso, raro biglanduloso na base; lâmina 3,5$14,8 \times 1,5-6,8 \mathrm{~cm}$, lanceolada a oval, base obtusa, ápice agudo, cuspidado, margem plana; face adaxial glabra; a abaxial esparso-serícea a glabrescente, com 2-12 glândulas intramarginais. Corimbos 3- ou 4floros; brácteas 0,8-1,1 mm compr.; bractéolas 0,7-1 mm compr., elípticas a ovais; pedicelos 2,8-12,1 mm compr., pedunculados. Sépalas $1,1-3,2 \times 0,7-1,8 \mathrm{~mm}$, ápice plano, seríceo-esverdeadas a seríceo-castanhas; as laterais biglandulosas e a anterior eglandulosa, ou todas biglandulosas. Pétalas amarelas, membranáceas, margem erosa; as laterais reflexas, limbo 2,7-3,4 $\times$ 2,1-2,8 mm; a posterior patente, limbo 2,6-3,1 × 1,7-2 $\mathrm{mm}$. Estames desiguais; filetes glabros, 1,3-3,7 $\mathrm{mm}$ compr.; anteras glabras, eretas. Ovário seríceo; estiletes 1,8-3,7 $\mathrm{mm}$ compr., retos, divergentes distalmente, os posteriores arqueados na base, glabros ou raro pilosos na base, ápice dorsalmente arredondado ou obtuso; estigmas laterais, voltados para o centro da flor. Samarídeos seríceos; ala dorsal 17,1-23,4 mm compr.; núcleo seminífero liso.

Ocorre na Bahia, Espírito Santo, Minas Gerais, Paraná, Rio de Janeiro, Santa Catarina e São Paulo (Sebastiani \& Mamede 2010; Amorim 2014). G8, H8, J8: em florestas ombrófilas montanas e submontanas e florestas estacionais semideciduais, entre 40 e $500 \mathrm{~m}$ s.n.m. Coletada com flores e frutos em janeiro e fevereiro.

Material selecionado - Alcobaça, $17^{\circ} 31^{\prime} \mathrm{S}, 39^{\circ} 11^{\prime} \mathrm{W}, 6$ fev. 2004 (bot., fl.), L. Kollmann et al. 6517 (CEPEC); Almadina, 14\%44'S, 39²42'W, 27 jan. 1999 (fl., fr.), W.W. Thomas 11841 (CEPEC, SP); Camacan, 15²3'30"S, 39 33'55"W, 2 fev. 2005 (fr.), A.M. Amorim et al. 4745 (CEPEC, HUEFS, SP); Pau Brasil, $15^{\circ} 27^{\prime} \mathrm{S}, 39^{\circ} 39^{\prime} \mathrm{W}, 4$ jan. 2000 (fr.), A.M. Amorim et al. 3225 (CEPEC, SP, UESC).

Heteropterys intermedia é caracterizada pela lâmina foliar lanceolada a oval, com margem não revoluta, face adaxial glabra e abaxial esparso-serícea a glabrescente, geralmente com 2-12 glândulas intramarginais, pedicelo 2,8-12,1 $\mathrm{mm}$ compr. e estiletes de 1,8-3,7 mm compr., glabros ou raramente pilosos na base. Outra característica diagnóstica de $H$. intermedia são as inflorescências com aspecto cônico (Sebastiani \& Mamede 2010), além do pedúnculo diminuto e estiletes com ápice em geral arredondado. Assemelha-se a $H$. pauciflora pela forma e dimensão da lâmina foliar, porém a margem é plana em $H$. intermedia (vs. ondulada em $H$. pauciflora) e a inflorescência frondobracteosa com o número de corimbos diminuindo para o ápice dos ramos em $H$. intermedia (vs. panículas axilares com até 6 pares de corimbos laterais e um terminal em $H$. pauciflora) (Sebastiani \& Mamede 2010). Heteropterys intermedia pertence à subseção Stenophyllarion e não consta na lista de espécies ameaçadas da flora brasileira (Amorim et al. 2013).

\section{Heteropterys jardimii Amorim, Rodriguésia 56: 175.} 2005.

Figura 11; Amorim (2005: fig. 1).

Liana, 4-6 m alt. Folhas cartáceas a coriáceas; pecíolo 4-10 mm compr., tomentoso, base biglandulosa; lâmina 10-22,3 × 3,8-10,5 cm, lanceolada, oval, oboval a subcordada, base obtusa, arredondada a cordada, ápice agudo, obtuso, acuminado ou cuspidado, margem plana; face adaxial tomentosa a glabrescente; a abaxial tomentosa, com 6 ou mais glândulas. Umbelas 4-6floras; brácteas 3,5-8 mm compr.; bractéolas 0,5-0,9 mm compr., ovais; pedicelos 3-5 mm compr., sésseis. Sépalas 1,7-2,4 × 1,5-1,7 mm, ápice plano, tomentosoferrugíneas, eglandulosas. Pétalas amarelas, crassas, carenadas; as laterais patentes, limbo 4,3-4,7 × 3,8-4 $\mathrm{mm}$, margem inteira a erosa, com um dos lados da base sagitada; a posterior ereto-patente, limbo 3,5-3,8 × 33,4 mm, margem erosa a glanduloso-espessada. Estames desiguais; filetes glabros, 1,9-3 mm compr.; anteras glabras, eretas. Ovário tomentoso; estiletes 2,12,8 mm compr., retos a curvilíneos, arqueados na base, glabros, ápice dorsalmente apiculado ou obtusoapiculado; estigmas laterais, voltados para o centro da flor. Samarídeos seríceos a glabrescentes; ala dorsal 26-43,6 mm compr.; núcleo seminífero com nervuras laterais conspícuas.

Distribuição restrita à Floresta Atlântica da Bahia (Amorim 2005, 2014). E8, F8, G8: em florestas ombrófilas montanas, entre 200 e 500 m s.n.m. Coletada com flores de janeiro a maio e junho e com frutos em janeiro, março e maio.

Material selecionado - Amargosa, $13^{\circ} 10^{\prime} \mathrm{S}, 39^{\circ} 09^{\prime} \mathrm{W}, 17$ mar. 2007 (fl., fr.), J.L. Paixão et al. 1099 (HUEFS); Santa Teresinha, $12^{\circ} 51^{\prime} 13^{\prime \prime S}, 39^{\circ} 28^{\prime} 33^{\prime \prime W, ~} 24$ fev. 2000 (fl.), J.G. Jardim et al. 2828 (holótipo CEPEC; isótipos ALCB, HUEFS, MICH foto); Ubaitaba, $14^{\circ} 18^{\prime} \mathrm{S}, 39^{\circ} 19^{\prime} \mathrm{W}, 16$ jun. 1972 (bot.), T.S. Santos 2306 (CEPEC, $\mathrm{MICH}$ foto).

Heteropterys jardimii é caracterizada pelo indumento densamente ferrugíneo-tomentoso revestindo os ramos, 
pétalas laterais com o limbo sagitado em um dos lados da base, estiletes com estigmas voltados para o centro da flor e arqueados na base. Assemelha-se a $H$. cordifolia (ver comentário naquela espécie). Heteropterys jardimii pertence à subseção Aptychia e não consta na lista de espécies ameaçadas da flora brasileira (Amorim et al. 2013).

24. Heteropterys leschenaultiana A.Juss., Fl. Bras. Merid. 3: 26. 1832 [1833].

Figuras 8 e 23H; Sebastiani \& Mamede (2010: fig. 8).

Liana, ca. $5 \mathrm{~m}$ alt. Folhas cartáceas; pecíolo 0,7-20 mm compr., glabro, base biglandulosa; lâmina 3,8$14,2 \times 1,2-6,2 \mathrm{~cm}$, elíptica a oval, base obtusa, ápice agudo, acuminado ou cuspidado, margem plana a revoluta; face adaxial glabra; a abaxial esparso-serícea a glabrescente, com 8-12 glândulas marginais. Corimbos 5- ou 6-floros; brácteas 0,8-2,2 mm compr.; bractéolas 0,7-1 mm compr., elípticas; pedicelos 1,87,9 mm compr., pedunculados. Sépalas 1,9-3,1 × 0,91,5 mm, ápice plano, seríceo-castanhas; as laterais biglandulosas e a anterior eglandulosa, ou todas biglandulosas. Pétalas amarelas, membranáceas; as laterais patentes, limbo 3,2-4,5 × 2-2,7 mm, margem inteira a erosa; a posterior ereto-patente a patente, limbo 2,5-3,3 × 2,2-2,6 mm, margem erosa. Estames desiguais; filetes glabros, 1,5-3,7 mm compr.; anteras glabras, eretas. Ovário seríceo; estiletes 1,7-3,5 mm compr., retos, divergentes distalmente, os posteriores arqueados na base, pilosos na base, ápice dorsalmente apiculado-uncinado; estigmas laterais, o anterior voltado para o centro da flor, os posteriores para as pétalas latero-posteriores. Samarídeos seríceos; ala dorsal 13,1-30,3 mm compr.; núcleo seminífero liso, raro com nervuras laterais inconspícuas.

Ocorre na Bahia, Espírito Santo e Rio de Janeiro (Sebastiani \& Mamede 2010; Amorim 2014). G8, H8, I8, J8: em florestas ombrófilas submontanas e de terras baixas, entre 40 e 350 m s.n.m. Coletada com flores de janeiro a setembro e com frutos em abril e de agosto a outubro.

Material selecionado - Caravelas, $17^{\circ} 43^{\prime} \mathrm{S}, 39^{\circ} 15^{\prime} \mathrm{W}, 19$ jun. 1985 (bot., fl.), G. Hatschbach 49474 (CEPEC); Ilhéus, 1454'S, 3905'W, 11 set. 2009 (fl., fr.), R.O. Perdiz \& L.C. Gomes 513 (CEPEC); Jussari, $15^{\circ} 09^{\prime} \mathrm{S}, 39^{\circ} 31^{\prime} \mathrm{W}, 3$ out. 2000 (fr.), W.W.

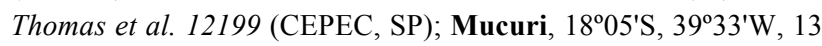
jul. 1968 (fl.), R.P. Belem 3846 (CEPEC, HUEFS); Santa Cruz Cabrália, $16^{\circ} 23^{\prime} \mathrm{S}, 39^{\circ} 08^{\prime} \mathrm{W}, 5$ ago. 1986 (fr.), T.S. Santos et al. 4279 (CEPEC); Santa Luzia, 15²5'S, 39²0'W, 10 ago. 1999 (fl., fr.), A.M. Amorim et al. 3090 (CEPEC, SP); Teixeira de Freitas, $17^{\circ} 25^{\prime} 49^{\prime \prime S}, 39^{\circ} 41^{\prime} 14^{\prime \prime W}, 18$ jun. 2005 (f1.), J.G. Jardim et al. 4621 (CEPEC, HUEFS); Ubaitaba, 14 $18^{\prime} \mathrm{S}, 39^{\circ} 19^{\prime} \mathrm{W}, 7$ set. 1999 (fl., fr.), A.M. Carvalho et al. 6811 (CEPEC, HUEFS, MBM); Una, $15^{\circ} 17^{\prime} \mathrm{S}, 39^{\circ} 04^{\prime} \mathrm{W}, 27$ set. 1979 (fr.), S.A. Mori 12814 (CEPEC, RB).

Heteropterys leschenaultiana é caracterizada pelo pecíolo glabro, lâmina foliar com 12 glândulas marginais diminutas na face abaxial, estiletes pilosos no terço-basal e samarídeos com ala dorsal 13,1-30,3 mm compr. Assemelha-se a $H$. wiedeana pelo pecíolo com base glandulosa, forma e consistência da lâmina foliar, inflorescências em panículas axilares ou terminais, mas diferem pela dimensão da lâmina foliar e sua margem (inteira em $H$. leschenaultiana e denticulada em $H$. wiedeana), comprimento das brácteas e pilosidade dos estiletes. Heteropterys leschenaultiana pertence à subseção Stenophyllarion e não consta na lista de espécies ameaçadas da flora brasileira (Amorim et al. 2013).

25. Heteropterys macradena (DC.) W.R.Anderson, Mem. New York Bot. Gard. 32: 202. 1981. Figuras 7 e 20M-Q.

Arbusto, ca. $7 \mathrm{~m}$ alt. Folhas papiráceas a coriáceas; pecíolo 2,8-7,9 $\mathrm{mm}$ compr., seríceo a glabrescente, eglanduloso; lâmina 4,5-11,5 × 1,5-5,7 $\mathrm{cm}$, oval ou elíptica, base aguda ou obtusa, ápice acuminado, margem ondulada; ambas as faces glabras; a abaxial com 6-8 glândulas marginais. Corimbos 12-floros a multifloros; brácteas 1,5-1,9 mm compr.; bractéolas 1,3-2,1 mm compr., ovais; pedicelos 3,8-5,9 mm compr., pedunculados. Sépalas 2,6-4,2 × 1,3-1,6 $\mathrm{mm}$, ápice revoluto, seríceocastanhas a seríceo-ferrugíneas; as laterais biglandulosas e a anterior eglandulosa, ou todas eglandulosas. Pétalas amarelas, membranáceas, margem erosa; as laterais sub-reflexas a patentes, limbo 5,6-6 × 4,2-5,4 $\mathrm{mm}$; a posterior patente a eretopatente, limbo 4,7-5,5 × 4,2-4,8 mm. Estames desiguais; filetes glabros, 2-3,2 mm compr.; anteras desiguais, ápice piloso, ressupinadas. Ovário seríceo; estiletes 2,8-3,2 mm compr., retos, divergentes distalmente, o anterior inclinado para a sépala anterior, os posteriores arqueados na base, glabros, ápice dorsalmente truncado ou obtuso-apiculados; estigmas laterais, voltados para a pétala posterior. Samarídeos seríceos; ala dorsal 28,7-45,6 mm compr.; núcleo seminífero com nervuras laterais inconspícuas.

Ocorre nas Guianas e no Brasil (Amapá, Amazonas, Maranhão, Mato Grosso do Sul e Rondônia) (Anderson 1997; Amorim 2014). Com o registro na Floresta Atlântica da Bahia, sua distribuição e área de ocorrência são aqui ampliadas. H8: em florestas ombrófilas submontanas, entre 80 e 300 m s.n.m. Coletada com flores e frutos em janeiro.

Material examinado - Camacan, $15^{\circ} 32^{\prime} 48^{\prime \prime} \mathrm{S}, 39^{\circ} 29^{\prime} 00^{\prime \prime} \mathrm{W}, 9$ jan. 2003 (fl., fr.), J.G. Jardim et al. 4118 (CEPEC, HUEFS); ib., $15^{\circ} 33^{\prime} \mathrm{S}, 39^{\circ} 29^{\prime} \mathrm{W}, 9$ jan. 2003 (fl., fr.), J.G. Jardim et al. 4123 (CEPEC, HUEFS); Una, 1509'35"S, 3903'17"W, 15 jan. 2004 (fr.), A.M. Amorim et al. 3898 (CEPEC); ib., 1509'35"S, $39^{\circ} 03^{\prime} 17^{\prime \prime W}, 15$ jan. 2004 (fl.), A.M. Amorim et al. 3900 (CEPEC).

Heteropterys macradena é caraterizada pelas bractéolas com 2-6 glândulas e ala dorsal dos samarídeos com disposição perpendicular. Assemelhase a $H$. grandiflora (ver comentário naquela espécie), pertence ao subgênero Parabanisteria e não consta na lista de espécies ameaçadas da flora brasileira (Amorim et al. 2013). 


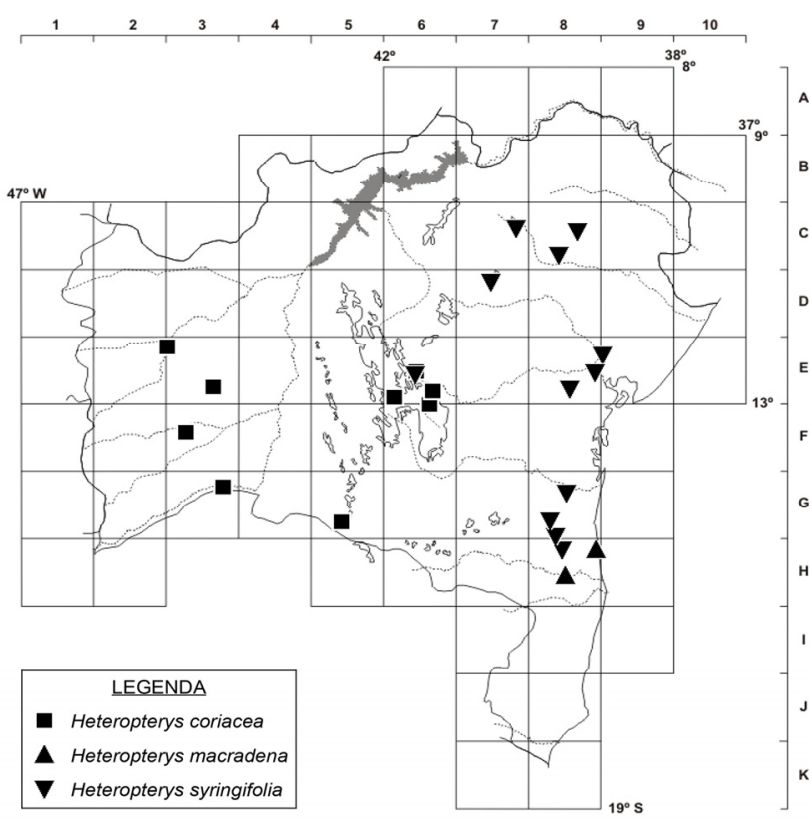

Figura 7. Mapa de distribuição de Heteropterys coriacea, H. macradena e H. syringifolia no estado da Bahia.

26. Heteropterys macrostachya A.Juss., Ann. Sci. Nat., Bot. II, 13: 275. 1840.

Figuras 11 e $17 \mathrm{M}-\mathrm{Q}$.

Liana, 4-20 m alt. Folhas cartáceas a coriáceas; pecíolo 5,1-23,9 $\mathrm{mm}$ compr., seríceo, terço-médio e ápice com 2-4 glândulas; lâmina 6,4-19,2 × 4,4-10,5 $\mathrm{cm}$, oval a suborbicular, base obtusa a subcordada, ápice emarginado-mucronado, margem revoluta; face adaxial glabra; a abaxial serícea, com 8 ou mais glândulas intramarginais ou próximas à margem. Umbelas 2-4-floras; brácteas 2-2,6 $\mathrm{mm}$ compr.; bractéolas 1,5-2,2 mm compr., ovais; pedicelos 2,44,6 mm compr., pedunculados. Sépalas $1,5-2,8 \times 1,2-$

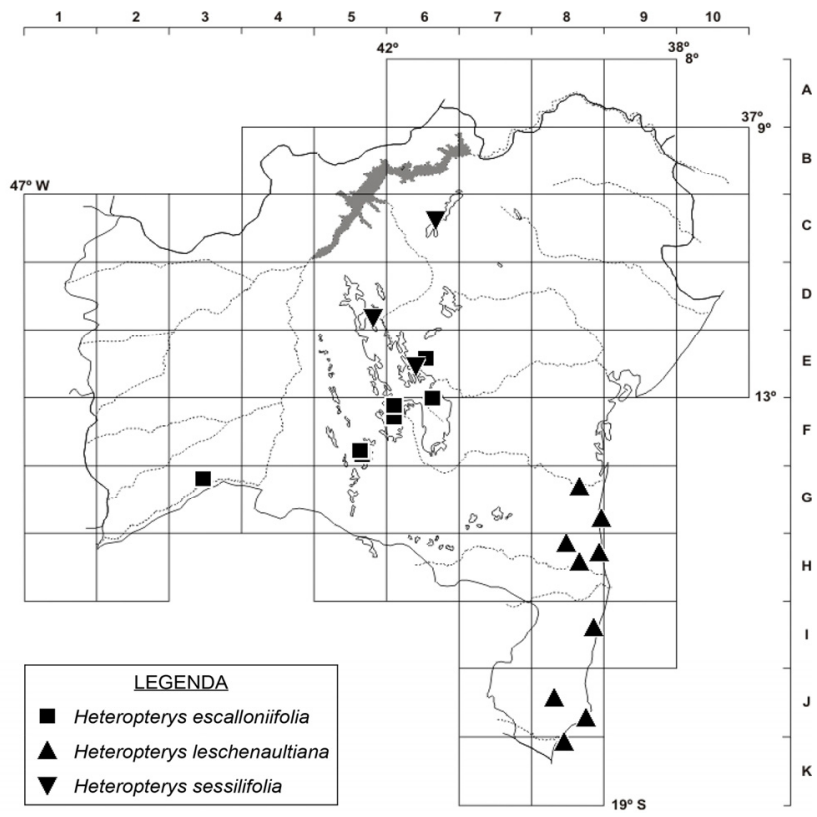

Figura 8. Mapa de distribuição de Heteropterys escalloniifolia, H. leschenaultiana e H. sessilifolia no estado da Bahia.
2,2 $\mathrm{mm}$; ápice plano; indumento seríceo-ferrugíneo; laterais biglandulosas e anterior eglandulosa. Pétalas amarelas, crassas; as laterais patentes a reflexas, limbo $3,2-4,8 \times 2,1-3,4 \mathrm{~mm}$, margem erosa; a posterior patente a ereto-patente, limbo 3,5-4,2 × 2,6-3,6 mm, margem fimbriada a erosa. Estames desiguais; filetes pilosos na base, $0,7-1,1 \mathrm{~mm}$ compr.; anteras glabras, eretas a ressupinadas. Ovário seríceo; estiletes 1,3-1,9 $\mathrm{mm}$ compr., retos, divergentes distalmente, glabros, ápice dorsalmente apiculado ou obtuso-apiculado; estigmas laterais, voltados para o centro da flor. Samarídeos seríceos a glabrescentes; ala dorsal 30$66,2 \mathrm{~mm}$ compr.; núcleo seminífero rugoso e com cristas laterais inconspícuas.

Distribuição ampla na América Central, Bolivia, Brasil (AC, AM, BA, ES, RO e SE), Guianas e norte da Venezuela (Anderson 1997; Amorim 2004, 2014). D7, E7, F6, G7, H7, H8, I8: em florestas ombrófilas submontanas e de terras baixas e florestas estacionais semideciduais e deciduais, entre 100 e 900 m s.n.m. Coletada com flores de março a maio e com frutos de julho a setembro.

Material selecionado - Abaíra, 13º' $14^{\prime} \mathrm{S}, 4^{\circ} 39^{\prime} \mathrm{W}, 14$ abr. 1999 (est.), A.M. Amorim et al. 2851 (CEPEC); Belmonte, 1608'S, $39^{\circ} 15^{\prime} \mathrm{W}, 13$ maio 1993 (bot., fl.), W.W. Thomas 9913 (CEPEC, SP); Boa Nova, 14²1'45"S, 40¹2'27"W, 11 abr. 2013 (bot., fl.), G.S. Brandão et al. 250 (HUESB); Encruzilhada, 15³0'54"S, 4048'51"W, 17 ago. 2001 (fr.), A.M. Carvalho et al. 6977 (ALCB, CEPEC, HUEFS, NY foto); Guaratinga, $16^{\circ} 35^{\prime} \mathrm{S}, 39^{\circ} 46^{\prime} \mathrm{W}, 29 \mathrm{abr}$. 1973 (bot.), R.S. Pinheiro 2066 (CEPEC); Itaberaba, 12²4'44"S, 40³2'12"W, 19 ago. 2005 (fr.), L.P. Queiroz et al. 10780 (CEPEC, HUEFS); Mundo Novo, $12^{\circ} 02^{\prime} \mathrm{S}, 40^{\circ} 29^{\prime} \mathrm{W}, 29$ mar. 2007 (fl.), P.A. Melo 192 (HUEFS); Tapiramutá, $11^{\circ} 50^{\prime} \mathrm{S}, 40^{\circ} 47^{\prime} \mathrm{W}$, jul. 1972 (fr.), G.C.P. Pinto s.n. (ALCB, SP); Una, 15º9'S, 3905'W, 1 maio 1996 (bot., fl.), J.G. Jardim et al. 817 (CEPEC).

Heteropterys macrostachya é caracterizada pelo pecíolo de 5,1-23,9 mm compr., com 2-4 glândulas distribuídas entre o terço-médio e o ápice, lâmina foliar 6,4-19,2 × 4,4-10,5 cm, em geral oval e com várias glândulas intramarginais ou próximas à margem (às vezes dando aspecto denticulado à margem), pétala posterior com margem fimbriada da base ao terçomédio e erosa no ápice e samarídeos com ala dorsal 30-66,2 mm compr. Assemelha-se a H. sericea (Cav.) A.Juss. pelo pecíolo glanduloso e últimas unidades da inflorescência em umbelas 6-floras, diferindo pelas glândulas intramarginais em $H$. macrostachya (vs. marginais em $H$. sericea). As semelhanças morfológicas com $H$. sericea são bastante evidentes, em especialmente nas coleções Macedo 282 e Thomas 12541 de Jequié, Ferreira 1877 de Brejões, Thomas 12203, Amorim 3671 e Fiaschi 1932 de Jussari e Pinto s.n. de Tapiramutá. Heteropterys sericea é endêmica do Cerrado e Floresta Atlântica do Sudeste do Brasil (Amorim 2014), até então sem registros para a Bahia. Pelo fato das amostras na Bahia relacionadas a essa espécie estarem em sua maioria em frutos ou estéreis, seu registro para o Estado ainda é incerto, exigindo material mais completos. Heteropterys macrostachya 
pertence à série Metallophyllis e não consta na lista de espécies ameaçadas da flora brasileira (Amorim et al. 2013).

27. Heteropterys megaptera A.Juss., Ann. Sci. Nat., Bot. II, 13: 277. 1840.

Figura 9; Anderson et al. (2006).

Liana. Folhas coriáceas; pecíolo 8-16 $\mathrm{mm}$ compr., seríceo, eglanduloso; lâmina 4,4-11,3 × 1,9-6,2 cm, oval a lanceolada, base cuneada, ápice acuminado, raro mucronado, margem revoluta; face adaxial glabra; a abaxial glabrescente, com 4-6 glândulas basais e intramarginais. Umbelas 4-6floras; brácteas 1,3-2 mm compr.; bractéolas 0,9-1,4 $\mathrm{mm}$ compr, ovais; pedicelos 2,3-7,6 $\mathrm{mm}$ compr., pedunculados. Sépalas $2-2,2 \times 1,2-1,5 \mathrm{~mm}$, ápice plano, seríceo-castanhas a seríceo-ferrugíneas; as laterais biglandulosas e a anterior eglandulosa, ou todas eglandulosas. Pétalas amarelas, membranáceas, margem erosa; as laterais patentes a sub-reflexas, limbo 3-3,7 × 2,1-2,6 mm; a posterior ereta, limbo 2,5-2,9 $\times$ 1,7-2,1 mm. Estames desiguais; filetes glabros, 0,9-1 mm compr.; anteras pilosas, eretas a ressupinadas. Ovário seríceo; estiletes 1,1-2,2 mm compr., o anterior curvilíneo, maior e inclinado para a sépala anterior, os posteriores retos e paralelos entre si, gabros, o anterior com ápice dorsalmente apiculado e os posteriores arredondados; estigmas laterais, voltados para o centro da flor. Samarídeos seríceos; ala dorsal 46,8-61 mm compr.; núcleo seminífero com nervuras laterais conspícuas.

Ocorre no Brasil (BA, ES, PE e RJ) (Amorim 2014), Guianas e Venezuela (Funk et al. 2007). G7, H8: em florestas ombrófilas submontanas, entre 160 e 440 m s.n.m. Coletada com flores em novembro e com frutos em junho e julho.

Material examinado - Boa Nova, $14^{\circ} 24^{\prime} 45^{\prime \prime} \mathrm{S}, 40^{\circ} 08^{\prime} 11^{\prime \prime} \mathrm{W}, 30$ jul 2013 (fr.), G.S. Brandão \& G.S. Silva 344 (HUESB); Una, $15^{\circ} 09^{\prime} \mathrm{S}, 39^{\circ} 05^{\prime} \mathrm{W}, 6$ jun. 1996 (fr.), A.M. Carvalho et al. 6206 (CEPEC, NY foto).

Material adicional examinado - BRASIL. ESPÍRITO SANTO: Linhares, $19^{\circ} 23^{\prime} 28^{\prime \prime} \mathrm{S}, 40^{\circ} 04^{\prime} 20^{\prime \prime} \mathrm{W}, 3$ nov. 1972 (fl.), $D$. Sucre 8437 (CEPEC, RB); ib., 19²3'28"S, 4004'20"W, 23 maio 2006 (fr.), D.A. Folli 5279 (SP). RIO DE JANEIRO: Corcovado, 18 mar. 1977 (est.), A.P. Duarte s.n. (RB 60840); Rio de Janeiro, $19^{\circ} 23^{\prime} 28^{\prime \prime S}, 40^{\circ} 04^{\prime} 20^{\prime \prime W}, 3$ fev. 1928 (est.), Pessoal do Horto Florestal 555 (CEPEC, RB).

Heteropterys megaptera é caracterizada pela lâmina foliar com base cuneada, ápice geralmente acuminado, face abaxial com 4-6 glândulas marginais e basais, anteras pilosas, estiletes com ápice dorsalmente misto, o anterior apiculado e os posteriores arredondados, o anterior inclinado para a sépala anterior e maior que os posteriores, que são retos e paralelos, e samarídeos com ala dorsal bem desenvolvida. Está relacionada à série Madarophyllis Nied., juntamente com $H$. bahiensis Nied. e $H$. sincorensis, que se assemelham pela face abaxial da lâmina foliar com uma fileira de

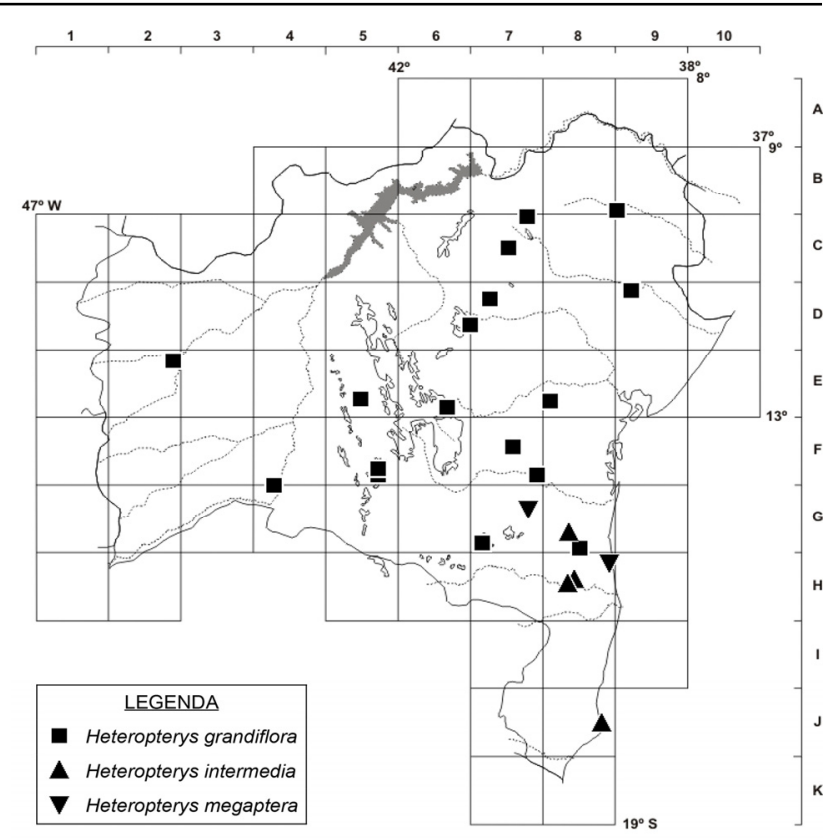

Figura 9. Mapa de distribuição de Heteropterys grandiflora, $H$. intermedia e H. megaptera no estado da Bahia.

glândulas intramarginais da base ao ápice, pedicelo pedunculado com as bractéolas inseridas na articulação entre o pedúnculo e o pedicelo, sépalas não encobrindo as pétalas na pré-antese e núcleo do samarídeos sem álulas ou cristas laterais (Amorim \& São-Mateus 2009). No entanto, H. megaptera difere pelas folhas não apressas aos ramos, lâmina foliar oval a lanceolada, glândulas do cálice glabras e anteras pilosas. Apesar do holótipo de $H$. bahiensis ter sido supostamente coletado na Bahia (Blanchet 1458), Amorim e São-Mateus (2009) indicaram sua ocorrência apenas para o norte do Espirito Santo. Heteropterys megaptera é uma espécie em perigo (Amorim et al. 2013).

28. Heteropterys nervosa A.Juss., Fl. Bras. Merid. 3: 26. 1833.

Figuras 10 e 20R-T.

Arbusto, 1,5-7 m alt. Folhas coriáceas; pecíolo 1,6-7 mm compr., glabrescente, eglanduloso; lâmina 3,5-11 × 1,5-4,8 cm, lanceolada ou oval-lanceolada, base cuneada, ápice acuminado, margem revoluta; ambas as faces glabras; a abaxial com 8 ou mais glândulas intramarginais. Corimbos 4-8-floros; brácteas 1,7-2,3 mm compr.; bractéolas 1,3-1,5 $\mathrm{mm}$ compr., ovais; pedicelos 1,6-5,4 $\mathrm{mm}$ compr., pedunculados. Sépalas 2,4-3,1 $\times 1,1-1,7 \mathrm{~mm}$, ápice revoluto, seríceo-ferrugíneas; as laterais biglandulosas e a anterior eglandulosa, ou todas eglandulosas. Pétalas amarelas, membranáceas, margem erosa; as laterais patentes a sub-reflexas, limbo 3,1-3,3 × 2,4$2,7 \mathrm{~mm}$; a posterior patente, limbo $2-2,7 \times 1,6-2,6$ $\mathrm{mm}$. Estames desiguais; filetes glabros, 0,9-1,7 $\mathrm{mm}$ compr.; anteras glabras, ressupinadas. Ovário seríceo; estiletes 1,5-2,5 $\mathrm{mm}$ compr., curvilíneos, os posteriores arqueados na base, glabros, ápice 
dorsalmente apiculado-uncinado; estigmas laterais, às vezes com aparência de subapicais, voltados para a pétala posterior. Samarídeos seríceos; ala dorsal 20 27,3 mm compr.; núcleo seminífero com nervuras laterais conspícuas.

Ocorre no Brasil (AC, BA, GO, MG, MT, PA, RO e SP) e Guianas (Anderson 1997; Amorim 2014). D2, E5, E6, F3, F6, G3, G5: em campos rupestres e cerrados, entre 450 e 600 m s.n.m. Coletada com flores em abril e de setembro e novembro e com frutos em abril, outubro, novembro e janeiro.

Material selecionado - Andaraí, $12^{\circ} 42^{\prime} \mathrm{S}, 41^{\circ} 21^{\prime} \mathrm{W}, 18$ jan. 2006 (fr.), A.A. Conceição et al. 1721 (HUEFS); Barreiras, 11'52'42"S, 4527'14"W, 2 nov. 1987 (fl., fr.), L.P. Queiroz et al.

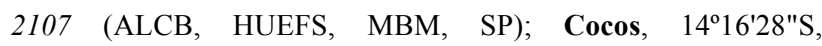
443'ㄷㄴ"W, 22 set. 2007 (fl.), M.L. Guedes et al. 13563 (ALCB,

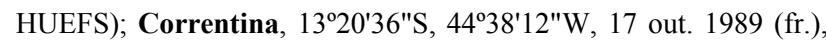
J.G. Violatti 93 (SP); Formosa do Rio Preto, 11\%03'29"S, 4515'07"W, 2 nov. 2007 (fr.), G. Araújo et al. 302 (HUEFS); Ibicoara, $13^{\circ} 18^{\prime} 56^{\prime \prime S}, 41^{\circ} 09^{\prime} 38^{\prime \prime W}, 13$ out. 2007 (fr.), M.L. Guedes et al. 13882 (ALCB); Licínio de Almeida, 14²45'04"S, 42³5'15"W, 3 nov. 2006 (fl., fr.), P.D. Carvalho et al. 374

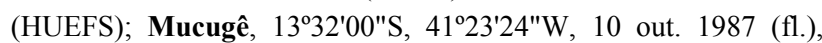
L.P. Queiroz 1837 (HUEFS, NY foto); Oliveira dos Brejinhos, $12^{\circ} 19^{\prime} \mathrm{S}, 42^{\circ} 53^{\prime} \mathrm{W}, 12$ out. 1981 (fl., fr.), G. Hatschbach 44176 (CEPEC, MBM, NY foto).

Heteropterys nervosa é caracterizada pela lâmina foliar de 3,5-11 cm compr., geralmente lanceolada, bractéolas 1,3-1,5 mm compr., sépalas de 2,4-3,1 mm compr., estigma lateral ou aparentemente subapical, samarídeos seríceos e com nervuras laterais conspícuas no núcleo seminífero. É semelhante a $H$. eglandulosa (ver comentário naquela espécie), pertence ao subgênero Parabanisteria e não consta na lista de espécies ameaçadas da flora brasileira (Amorim et al. 2013).

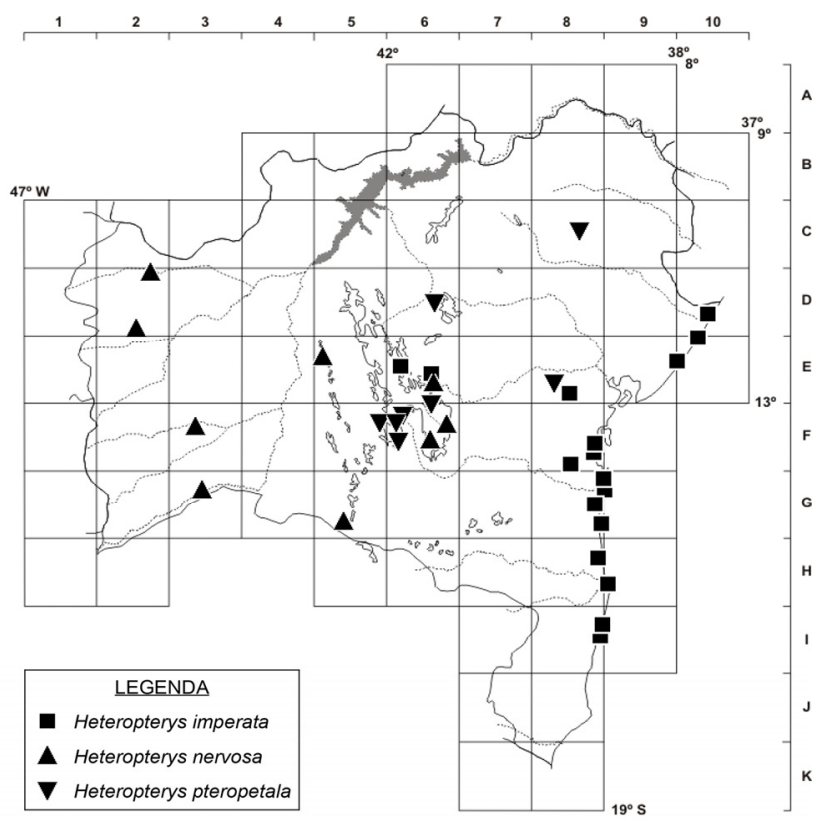

Figura 10. Mapa de distribuição de Heteropterys imperata, $H$. nervosa e $H$. pteropetala no estado da Bahia.
29. Heteropterys nitida (Lam.) DC., Prodr. 1: 592. 1824. Figuras 12 e 23B-D; Amorim (1994: fig. 27).

Arbusto ou liana, 2-15 $\mathrm{m}$ alt. Folhas membranáceas a cartáceas; pecíolo 2,3-8 mm compr., seríceo, eglanduloso; lâmina 2,4-21,2 × 1-7,5 cm, oblongo-elíptica a oblongo-oval, base obtusa a cuneada, ápice cuspidado, margem revoluta; face adaxial glabrescente, abaxial serícea a glabrescente; a abaxial com 6 ou mais glândulas intramarginais. Umbelas 2-4-floras; brácteas 1,4-2,4 $\mathrm{mm}$ compr.; bractéolas $0,9-1,5 \mathrm{~mm}$ compr., ovais; pedicelos 1,45,5 mm compr., pedunculados. Sépalas 2,1-2,9 × 1,11,6 mm, ápice plano, seríceo-castanhas; as laterais biglandulosas, a anterior eglandulosa. Pétalas amarelas, crassas, margem erosa; as laterais subreflexas, limbo $4,1-4,5 \times 2,4-2,8 \mathrm{~mm}$; a posterior patente, limbo 2,8-4,3 $\times$ 2,7-3 mm. Estames desiguais; filetes pilosos na base, $0,3-0,6 \mathrm{~mm}$ compr.; anteras glabras, eretas. Ovário seríceo; estiletes 0,91,4 mm compr., curvilíneos, glabros, ápice dorsalmente obtuso-apiculado; estigmas laterais, voltados para o centro da flor. Samarídeos seríceos; ala dorsal 33,847,6 mm compr.; núcleo seminífero com nervuras laterais inconspícuas.

Ocorre na Bahia, Espírito Santo, Goiás, Minas Gerais, Paraná, Rio de Janeiro, Santa Catarina e São Paulo (Amorim 2004, 2014). G7, G8, H8, J7: em florestas ombrófilas montanas e mais raramente submontanas, entre 50 e 1000 m s.n.m. Coletada com flores de dezembro a abril e em julho e com frutos em abril, agosto e outubro.

Material selecionado - Arataca, $15^{\circ} 10^{\prime} 25^{\prime \prime} \mathrm{S}, 39^{\circ} 20^{\prime} 30^{\prime \prime} \mathrm{W}, 13$ abr. 2006 (fl.), A.M. Amorim et al. 5732 (CEPEC); Barro Preto, 14 $46^{\prime} 13^{\prime \prime S}$, 39¹2'10"W, 26 abr. 2004 (fl.), A.M. Amorim 4105 (CEPEC); Boa Nova, 1425'13"S, 4007'22"W, 23 out. 2007 (fr.), F.M. Ferreira et al. 1617 (CEPEC); Camacan, 15'23'30"S, 39 33'55"W, 29 out. 2004 (est.), A.M. Amorim et al. 4389 (CEPEC); Ilhéus, $14^{\circ} 47^{\prime} \mathrm{S}, 39^{\circ} 02^{\prime} \mathrm{W}, 12$ fev. 1978 (bot., fl.), S.A. Mori 9261

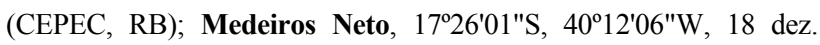
2008 (fl.), L.S. Almeida et al. 8 (HUEFS); Una, 1509'18"S, 39 18'07"W, 8 mar. 2001 (bot., fl.), J.G. Jardim et al. 3191 (CEPEC).

Heteroptery nitida é caracterizada pelo pecíolo eglanduloso, lâmina foliar geralmente grande, oblongo-elíptica, de ápice cuspidado, marcadamente discolor, com a face adaxial castanho-glabrescente e a abaxial verde-serícea, com númerosas glândulas intramarginais enegrescidas, filetes $0,3-0,6 \mathrm{~mm}$ compr. e estiletes com ápice em geral dorsalmente obtuso-apiculado. Pertence à série Metallophyllys e assemelha-se as demais espécies deste grupo por apresentar lâmina foliar com indumento dourado ou metálico-seríceo na face abaxial. No entanto, difere delas pelo indumento seríceo a glabrescente na face adaxial da lâmina foliar. No material Almeida 8 , foi relatada a presença de flores com odor durante o dia, característica reportada até aqui apenas para $H$. andersonii (Amorim 2004). Heteropterys nitida não consta na lista de espécies ameaçadas da flora brasileira (Amorim et al. 2013). 


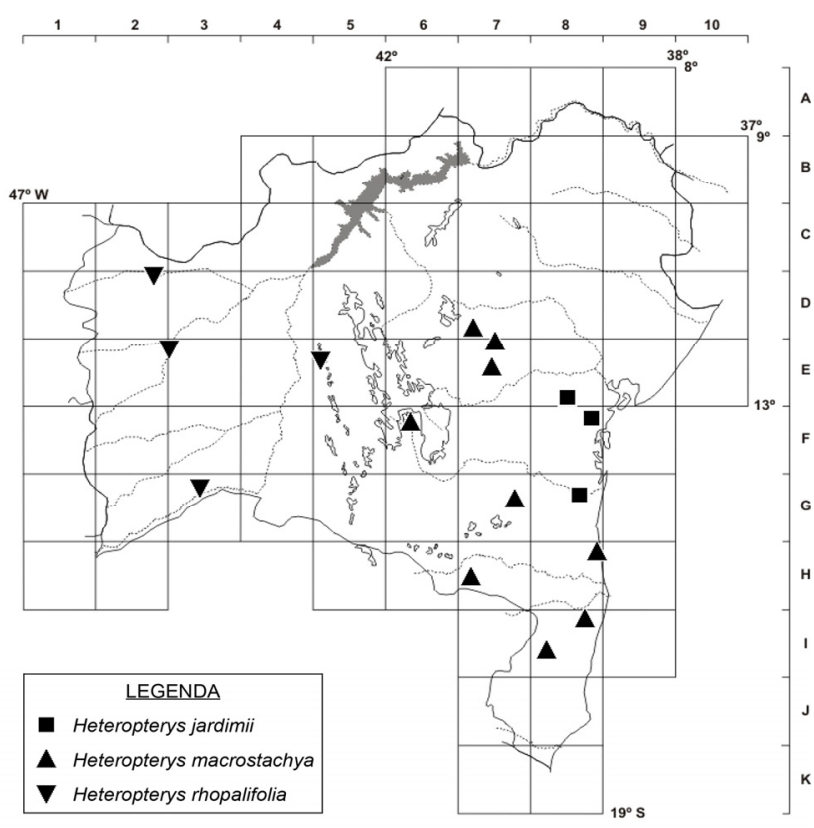

Figura 11. Mapa de distribuição de Heteropterys jardimii, H. macrostachya e H. rhopalifolia no estado da Bahia.

30. Heteropterys nordestina Amorim, Brittonia 55: 137. 2003.

Figura 13; Amorim (2003b: fig. 5).

Liana, 4-30 m alt. Folhas cartáceas a coriáceas; pecíolo 5-21 mm compr., seríceo a glabrescente, base biglandulosa; lâmina 2,1-20 × 2-11,5 cm, elíptica, oval, orbicular, oboval, raro orbicordada, base obtusa a arredondada, ápice agudo, arredondado, cuspidado, raro retuso, margem plana; face adaxial glabra; a abaxial glabrescente, com 6 ou mais glândulas marginais. Umbelas 4-6-floras; brácteas 1,3-4,5 mm compr.; bractéolas 0,4-1 mm compr., ovais; pedicelos 3,5-9,3 mm compr., sésseis. Sépalas 1,4-1,8 × 1,31,5 mm, ápice plano, seríceo-ferrugíneas; as laterais biglandulosas e a anterior eglandulosa, ou todas eglandulosas. Pétalas amarelas, crassas, carenadas; as laterais patentes, limbo 3,5-4,8 $\times 2,1-4,5 \mathrm{~mm}$, margem inteira ou erosa; a posterior ereta, limbo 2,5 $4 \times 2,4-3,3 \mathrm{~mm}$, margem glanduloso-espessada. Estames desiguais; filetes glabros, 2-3,5 mm compr.; anteras glabras, eretas. Ovário seríceo; estiletes 2,93,3 mm compr., retos, paralelos entre si, os posteriores arqueados na base, glabros, ápice dorsalmente apiculado ou truncado; estigmas laterais, voltados para o centro da flor. Samarídeos seríceos a glabrescentes; ala dorsal 33-44 mm compr.; núcleo seminífero liso.

Ocorre em Alagoas, Bahia, Espírito Santo, Paraiba, Pernambuco, Rio Grande do Norte e Sergipe (Amorim 2003a,b, 2014). D9, E8, E9, F7, F8, G8, H8, I8, J8: em florestas ombrófilas montanas, submontanas e de terras baixas, florestas semideciduais e restingas, entre 150 e 850 m s.n.m. Coletada com flores de fevereiro a agosto, em outubro e dezembro e com frutos de abril a agosto e em outubro.
Material selecionado - Amargosa, $13^{\circ} 10^{\prime} \mathrm{S}, 3^{\circ} 09^{\prime} \mathrm{W}, 29$ abr. 2007 (bot., fl.), J.L. Paixão et al. 1183 (CEPEC); Camacan, $15^{\circ} 23^{\prime} 30^{\prime \prime S}, 3^{\circ} 33^{\prime} 55^{\prime \prime W}, 21$ jun. 2008 (bot., fl.), A.M. Amorim et al.

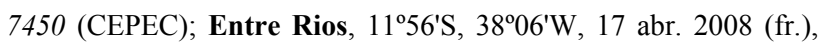
A.V. Popovkin \& D. Cardoso 219 (HUEFS); Ibirapitanga, 13'53'27"S, 39²7'33"W, 12 maio 2005 (bot., fl.), A.M. Amorim et al. 4952 (CEPEC); Ilhéus, 1458'40"S, 3902'07"W, 14 maio 1995 (fr.), W.W. Thomas 10909 (CEPEC, NY foto); Itacaré, 14²4'S, 39¹6'W, 2 maio 1993 (fl.), W.W. Thomas et al. 9764 (CEPEC,

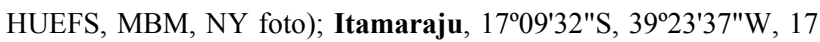
jun. 2005 (fl.), M.N.S. Stapf et al. 445 (HUEFS); Jequié, 135' $41^{\prime \prime S}, 40^{\circ} 06^{\prime} 34^{\prime \prime W}, 27$ abr. 2005 (bot., fl.), G.E.L. Macedo 1985 (CEPEC); Jussari, 1509'29"S, 39³1'43"W, 22 fev. 1998 (est.), A.M. Amorim et al. 2199 (CEPEC); Prado, $17^{\circ} 08^{\prime} \mathrm{S}, 39^{\circ} 25^{\prime} \mathrm{W}$, 20 out. 1993 (fr.), W.W. Thomas et al. 10013 (CEPEC, HUEFS, MBM, SP); Salvador, $12^{\circ} 58^{\prime} \mathrm{S}, 38^{\circ} 30^{\prime} \mathrm{W}, 24$ mar. 1986 (fl.), M.L. Guedes et al. s.n. (ALCB 20208); Santa Cruz Cabrália, $16^{\circ} 23^{\prime} \mathrm{S}$, $39^{\circ} 08^{\prime} \mathrm{W}, 29$ maio 1985 (fl.), F.S. Santos 486 (CEPEC, HUEFS, MBM, SP); Santa Teresinha, 12 $52^{\prime} 11^{\prime \prime S}, 39^{\circ} 28^{\prime} 37^{\prime \prime} \mathrm{W}, 20$ jul. 2004 (fr.), M.L.C. Neves et al. 78 (HUEFS, MBM); São Sebastião do Passé, $12^{\circ} 30^{\prime} \mathrm{S}, 38^{\circ} 29^{\prime} \mathrm{W}, 25$ mar. 2001 (bot.), D.M. Loureiro 8 (ALCB, CEPEC); Una, 15\%9'S, 39 $5^{\circ} \mathrm{W}, 9$ jun. 2000 (fr.), A.M. Amorim \& S.C. Sant'Ana 3433 (ALCB, CEPEC, HUEFS, MBM, SP); Uruçuca, $14^{\circ} 25^{\prime} \mathrm{S}, 39^{\circ} 1^{\prime} \mathrm{W}, 24$ jun. 1993 (fl.), A.M. Amorim et al. 1302 (CEPEC, SP).

Heteropterys nordestina é caracterizada pela lâmina foliar com face abaxial glabrescente, pétala posterior brevemente crassa e samarídeos com indumento seríceo a glabrescente. $\mathrm{O}$ espectro de variação torna complexa a caracterização dessa espécie e muitas vezes difícil sua separação de $H$. imperata e $H$. oberdanii (Amorim 2003a,b). Assemelha-se morfologicamente a $H$. imperata (ver comentário naquela espécie) e a $H$. oberdanii, pela forma e dimensão das estruturas florais, mas difere desta última pelas inflorescências com últimas unidades em umbelas 4-6-floras (vs. corimbos 4-20-floros em $H$. oberdanii). Entretanto, enquanto $H$. nordestina é encontrada em florestas ombrófilas montanas, submontanas e de terras baixas, florestas semideciduais e restingas, $H$. oberdanii é encontrada apenas em ambientes florestados de restinga periodicamente alagado (Amorim 2003a). Heteropterys nordestina pertence à subseção Aptychia e não consta na lista de espécies ameaçadas da flora brasileira (Amorim et al. 2013).

31. Heteropterys oberdanii Amorim, Brittonia 54: 229. 2003 [2002].

Figuras 12 e 23E; Amorim (2002: fig. 7).

Liana, 1,5-10 m alt. Folhas cartáceas; pecíolo 6$17 \mathrm{~mm}$ compr., seríceo a glabrescente, base biglandulosa; lâmina 1,8-10,5 × 0,8-4,3 cm, oblonga, oboval, oval, lanceolada, raro orbicular, base obtusa, raro arredondada, ápice agudo, obtuso, retuso, raro truncado ou apiculado, margem plana; ambas as faces glabrescentes, com 6 ou mais glândulas marginais. Corimbos 4-20-floros; brácteas 4-4,3 mm compr.; bractéolas $0,4-0,8 \mathrm{~mm}$ compr., ovais; pedicelos 3,5-6 $\mathrm{mm}$ compr., sésseis. Sépalas 2,2-2,6 × 1,7-2,1 mm; 
ápice plano; indumento seríceo-ferrugíneo; as laterais biglandulosas, anterior eglandulosa. Pétalas amarelas, crassas, carenadas; as laterais patentes, limbo 4,3-5,1 $\times$ 3,8-6,3 mm, margem inteira; a posterior ereta, limbo 2,8-3,7 × 3,4-3,9 mm, margem inteira e glandulosa. Estames desiguais; filetes glabros, 1,4-3 mm compr.; anteras glabras, eretas ou ressupinadas. Ovário seríceo; estiletes 2,9-4,4 $\mathrm{mm}$ compr., retos, os posteriores arqueados na base, glabros ou pilosos na base, ápice dorsalmente apiculado; estigmas laterais, voltados para o centro da flor. Samarídeos tomentosos a glabrescentes; ala dorsal 25-32 mm compr.; núcleo seminífero liso.

Distribuição restrita à Floresta Atlântica, na Bahia e no Espírito Santo (Amorim 2014). F8, I8: em florestas ombrófilas submontanas, a cerca de 150 m s.n.m. Coletada com flores e frutos em abril.

Material examinado - Belmonte, $16^{\circ} 08^{\prime} \mathrm{S}, 39^{\circ} 15^{\prime} \mathrm{W}, 2$ abr. 2003 (fl., fr.), P. Fiaschi et al. 1441 (CEPEC, NY foto); Cairu,

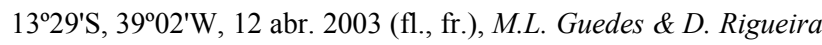
10259 (ALCB, CEPEC).

Material adicional examinado - BRASIL. ESPÍRITO SANTO: Guarapari, 203'ㄹ' S, 40²5'53"W, 21 fev. 2000 (bot.), A.M. Amorim 3346 (holótipo CEPEC, isótipo SP); Linhares, 19²3'28"S, 4004'20"W, 17 abr. 2001 (fr.), D.A. Folli 3896 (CEPEC, SP).

Heteropterys oberdanii é caracterizada pelo pecíolo de 6-17 mm compr., lâmina foliar 1,8-10,5 × 0,8-4,3 $\mathrm{cm}$, ambas as faces glabrescentes, inflorescência com últimas unidades em corimbos 4-20-floros, pedicelos 3,5-6 mm compr. e samarídeos róseos. Pertence à subseção Aptychia e assemelha-se a H. nordestina (ver comentário naquela espécie). Segundo Amorim et al. (2013), H. oberdanii é uma espécie vulnerável.

32. Heteropterys perplexa W.R.Anderson, Contr. Univ. Michigan Herb. 15: 120. 1982.

Figura 12; Anderson (1982: fig. 10).

Liana, 1,5-3 m alt. Folhas papiráceas a cartáceas; pecíolo 4-11 mm compr., tomentoso a glabrescente, base ou terço-médio biglanduloso; lâmina 1,3-12,6 $\times$ 0,8-7,6 cm, elíptica, oval a oboval, base cuneada a arredondada, ápice retuso, obtuso, agudo a acuminado, margem plana; face adaxial tomentosa a glabrescente; a abaxial velutina, com 2 glândulas intramarginais e próximo à base da lâmina. Umbelas ou corimbos 4 15-floros; brácteas 1,5-2,2 mm compr.; bractéolas 1,41,7 mm compr., ovais; pedicelos 1,9-7,3 mm compr., pedunculados. Sépalas 2,2-3,5 × 1,4-2 mm, ápice plano, seríceo-ferrugíneas a glabrescentes; as laterais biglandulosas, a anterior eglandulosa. Pétalas alvas com máculas róseas no centro, crassas, carenadas; as laterais reflexas, limbo 4,3-4,6 × 3,2-3,4 mm, margem inteira; a posterior ereta a ereto-patente, limbo 3-4,2 $\times$ 2,7-3,5 mm, margem erosa. Estames desiguais; filetes glabros, 1,3-2,2 mm compr.; anteras glabras, eretas. Ovário seríceo; estiletes 2,5-2,7 $\mathrm{mm}$ compr., retos, divergentes distalmente, glabros, ápice dorsalmente arredondado, apiculado ou truncado; estigmas laterais, voltados para o centro da flor. Samarídeos seríceos; ala dorsal 14,2-46,4 mm compr.; núcleo seminífero rugoso na lateral.

Ocorre na Bahia, Espírito Santo, Minas Gerais, Piauí e Rio de Janeiro (Amorim 2014). B9, C6, C7, C8, D5, D6, E2/3, E6, E7, E8, F3, F5, F6, F7, H8: em caatingas, campos rupestres, cerrados, florestas estacionais semideciduais e deciduais, entre 225 e $1.200 \mathrm{~m}$ s.n.m. Coletada com flores de janeiro a abril e com frutos de fevereiro a agosto.

Material selecionado - Barra do Mendes, $11^{\circ} 48^{\prime} \mathrm{S}, 42^{\circ} 03^{\prime} \mathrm{W}$, 27 jan. 2001 (fl.), E. Saar et al. 86 (HUEFS, CEPEC); Barreiras,

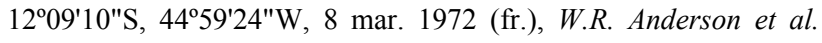

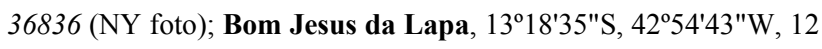
jan. 2008 (fl.), A. Rapini et al. 1493 (HUEFS); Campo Formoso, $10^{\circ} 24^{\prime} \mathrm{S}, 41^{\circ} 17^{\prime} \mathrm{W}, 5$ mar. 1974 (fl.), R.M. Harley 16775 (parátipo CEPEC); Coribe, 133' $10^{\prime \prime} \mathrm{S}, 4^{\circ} 19^{\prime} 12^{\prime \prime} \mathrm{W}, 11$ abr. 2007 (fr.), L.P. Queiroz et al. 12792 (HUEFS); Iaçu, 12²43'S, 4007'W, 14 mar. 1985 (fl.), L.R. Noblick 3692 (HUEFS, CEPEC, RB, UESC); Igaporã, $13^{\circ} 46^{\prime} 24^{\prime \prime S}, 42^{\circ} 42^{\prime} 51^{\prime \prime W}$, s.d., G. Hatschbach 55124 (MBM); Itaberaba, $12^{\circ} 30^{\prime} 05^{\prime \prime} \mathrm{S}, 40^{\circ} 04^{\prime} 55^{\prime \prime} \mathrm{W}, 4$ jun. 2005 (fr.), $E$.

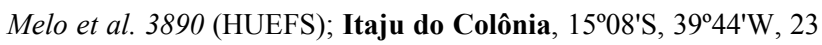
jan. 1969 (fl.), T.S. Santos 343 (CEPEC); Jaguarari, 1006'10"S, 40¹3'46"W, 13 abr. 2006 (fl.), R.F. Souza-Silva et al. 189 (CEPEC, HUEFS); Lençóis, $12^{\circ} 34^{\prime} \mathrm{S}, 4^{\circ} 23^{\prime} \mathrm{W}, 14$ abr. 2005 (fr.), A. Rapini \& A.A. Conceição 1165 (HUEFS); Maracás, $13^{\circ} 26^{\prime} \mathrm{S}, 40^{\circ} 25^{\prime} \mathrm{W}, 27$ fev. 2000 (fl.), R.P. Oliveira et al. 364 (CEPEC, HUEFS, UB); Milagres, 1252'S, 3949'W, 15 mar. 1997 (fl.), F. França et al. 2135 (CEPEC, HUEFS, UB); Monte Santo, 10²6'19"S, $39^{\circ} 20^{\prime} 09^{\prime \prime W}, 27$ fev. 2000 (fl.), A.M. Giulietti \& R.M. Harley 1863

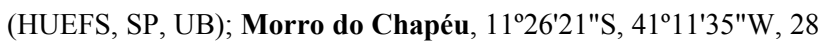
abr. 2011 (bot., fl.), E. Melo et al. 9610 (HUEFS); Paulo Afonso, $09^{\circ} 29^{\prime} \mathrm{S}, 38^{\circ} 12^{\prime} \mathrm{W}, 31$ ago. 2006 (fr.), R.S. Gonçalves 25 (HUEFS); Rio de Contas, $13^{\circ} 32^{\prime} \mathrm{S}, 41^{\circ} 57^{\prime} \mathrm{W}, 2$ jan. 2000 (fl.), A.M. Giulietti \& R.M. Harley 1646 (HUEFS, SP); Rui Barbosa, 12 ${ }^{\circ} 18^{\prime} 52^{\prime \prime S}$, 40'29'37"W, 25 mar. 2005 (fl.), D. Cardoso et al. 336

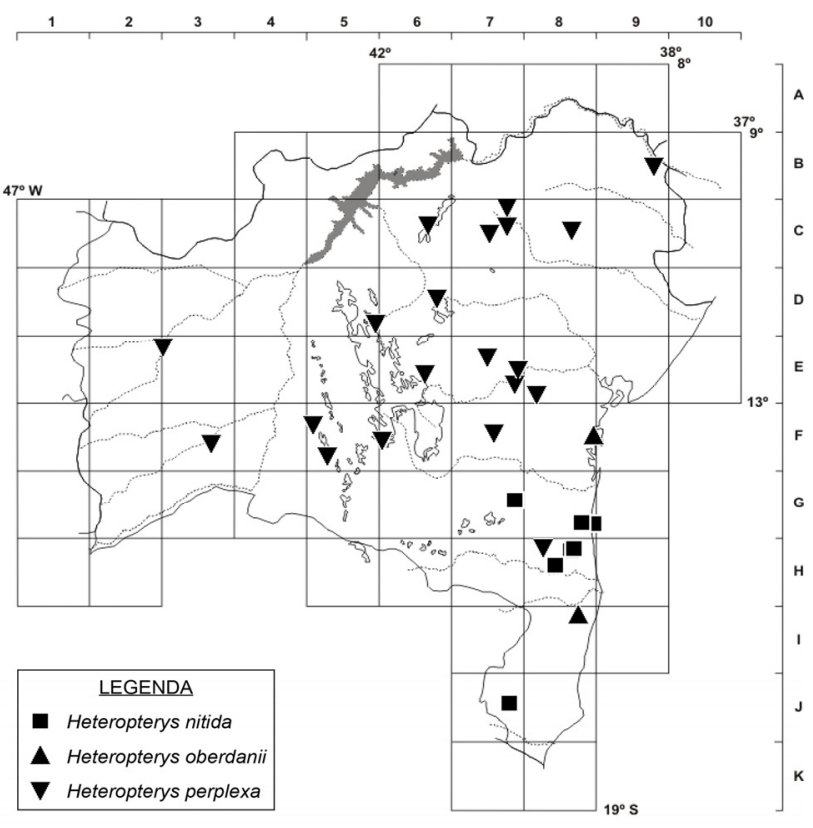

Figura 12. Mapa de distribuição de Heteropterys nitida, H. oberdanii e H. perplexa no estado da Bahia. 


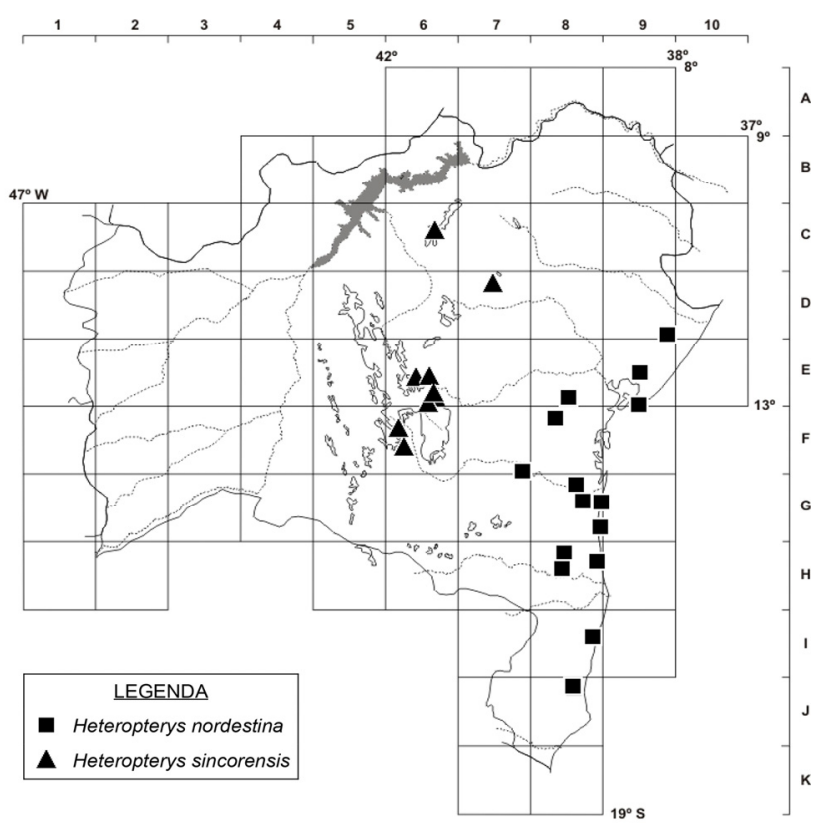

Figura 13. Mapa de distribuição de Heteropterys nordestina e H. sincorensis no estado da Bahia.

(CEPEC, HUEFS, NY foto); Senhor do Bonfim, $10^{\circ} 23^{\prime} 02^{\prime \prime} \mathrm{S}$, 40¹3'35"W, 14 jul. 2005 (fr.), D. Cardoso et al. 730 (HUEFS); Umburanas, $10^{\circ} 22^{\prime} \mathrm{S}, 41^{\circ} 19^{\prime} \mathrm{W}, 10$ abr. 1999 (fl.), L.P. Queiroz et al. 5287 (HUEFS, CEPEC).

Heteropterys perplexa é caracterizada pela lâmina foliar 1,3-12,6 × 0,8-7,6 cm, geralmente papirácea, com base cuneada a arredondada, com duas glândulas intramarginais próximo à base da lâmina e samarídeos com núcleo seminífero rugoso. Assemelha-se a $H$. caducibracteata (ver comentário naquela espécie) e a $H$. pteropetala pela consistência, dimensões e margem da lâmina foliar, diferenciando-se desta última pelo hábito, forma e quantidade de glândulas na face abaxial da lâmina foliar (Anderson 1982). Heteropterys perplexa pertence à série Rhodopetalis e não consta na lista de espécies ameaçadas da flora brasileira (Amorim et al. 2013).

33. Heteropterys pteropetala A.Juss., Fl. Bras. Merid. 3: 31.1833.

Figuras 10, 24A, B; Niedenzu (1928: fig. 27H, J-K).

Arbusto, 1-2,5 $\mathrm{m}$ alt. Folhas membranáceas a cartáceas, pecíolo 2,4-7,9 mm compr., tomentoso, eglanduloso, raro biglanduloso no ápice; lâmina 2-12,7 $\times 1,1-12 \mathrm{~cm}$, orbicular, oval, raro elíptica, base obtusa a cordada, ápice obtuso, arredondado, raro agudo, margem plana; face adaxial tomentosa a glabrescente; a abaxial tomentosa, com 2-4 glândulas próximo à base da lâmina. Corimbos 12-floros; brácteas 1,5-2 $\mathrm{mm}$ compr.; bractéolas 1,1-1,7 mm compr., ovais; pedicelos 2,3-4 mm compr., pedunculados. Sépalas 1,7-2,7 × 1,2-1,4 mm, ápice plano, tomentosoferrugíneas; as laterais biglandulosas, a anterior eglandulosa. Pétalas róseas, raro alvas, crassas, carenadas; as laterais reflexas a sub-reflexas, limbo 3,3-4,6 $\times$ 2-2,6 $\mathrm{mm}$, margem inteira a erosa; a posterior ereta a ereto-patente, limbo 3-3,5 × 2,4-2,5 $\mathrm{mm}$, margem erosa. Estames desiguais; filetes glabros, 1,9-3,2 mm compr.; anteras glabras, eretas a ressupinadas. Ovário tomentoso; estiletes 1,4-2 $\mathrm{mm}$ compr., retos, divergentes distalmente, o anterior menor que os posteriores, glabros, ápice dorsalmente apiculado, arredondado ou obtuso; estigmas laterais, voltados para o centro da flor. Samarídeos tomentosos; ala dorsal 26-32 $\mathrm{mm}$ compr.; núcleo seminífero com nervuras laterais conspícuas.

Ocorre na Bahia, Distrito Federal, Goiás, Minas Gerais e São Paulo (Mamede 2004; Amorim 2014). C8, D6, E8, F5, F6: em caatingas, campos rupestres e cerrados, entre 700 a 1350 m s.n.m. Coletada com flores de janeiro a abril e com frutos em julho e agosto.

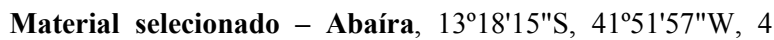
fev. 2003 (bot.), F. França et al. 4270 (CEPEC, HUEFS); Érico Cardoso, 13ำ16'16"S, 42 ${ }^{\circ} 5^{\prime} 54^{\prime \prime} \mathrm{W}, 4$ jul. 2001 (fr.), T. Ribeiro 321 (CEPEC, HUEFS, RB); Itatim, 1242'00"S, 3940'59"W, 23 mar. 2009 (f1.), M.L. Guedes et al. 14684 (ALCB); Monte Santo, 10²6'19"S, 39²0'09"W, 13 fev. 2011 (fl.), G. Costa 478 (HUEFS);

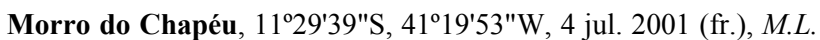

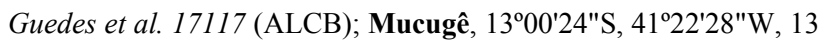
fev. 1997 (fl.), B. Stannard et al. PCD 5537 (ALCB, CEPEC); Piatã, $13^{\circ} 10^{\prime}$ S, $41^{\circ} 46^{\prime} \mathrm{W}, 13$ fev. 1987 (fl.), R.M. Harley et al. 24145

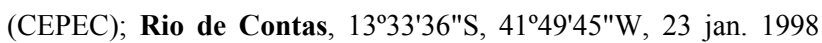
(fl.), F. França 2478 (CEPEC, HUEFS, UB).

Heteropterys pteropetala é caracterizada pelo hábito predominantemente arbustivo, lâmina foliar geralmente orbicular, com 2-4 glândulas próximo à base, últimas unidades da inflorescência em corimbos 12-floros e pétalas geralmente róseas. Devido à sua ampla variação morfológica, trata-se de uma espécie de diagnóstico complexo, relacionada a $H$. caducibracteata e $H$. perplexa (ver comentários nessas espécies), e os materiais da Bahia poderão ser segregados em um táxon a parte. Heteropterys pteropetala pertence à série Rhodopetalis e não consta na lista de espécies ameaçadas da flora brasileira (Amorim et al. 2013).

34. Heteropterys rhopalifolia A.Juss., Ann. Sci. Nat., Bot. II, 13: 274. 1840.

Figuras 11 e 19L-O.

Arbusto ou subarbusto, 1,5-2,5 m alt. Folhas cartáceas a coriáceas; pecíolo 2,2-5,3 mm compr., seríceo, eglanduloso; lâmina 3,5-10,8 × 1,8-6,2 cm, oval a oboval, base cuneada, ápice acuminado ou agudo, margem plana; face adaxial glabra; a abaxial tomentosa a glabrescente, com 2 glândulas conspícuas na base da lâmina. Corimbos 4-6-floros; brácteas 1,52,2 mm compr., bractéolas 1-1,8 mm compr., ovais; pedicelos 5,3-9,3 mm compr., pedunculados. Sépalas 2,6-3,4 × 1,4-1,9 mm, ápice plano, seríceoferrugíneas; as laterais biglandulosas, a anterior eglandulosa. Pétalas amarelas, membranáceas, margem erosa; as laterais patentes, limbo 5,1-5,7 $\times$ 3,7-4,8 mm; a posterior ereta, limbo 4,5-5,1 $\times 3,7-4,5$ mm. Estames desiguais; filetes glabros, 1,4-2,3 mm; 
anteras glabras, eretas a ressupinadas. Ovário seríceo; estiletes 2-2,6 $\mathrm{mm}$ compr., retos, divergentes distalmente, o anterior maior que os posteriores, pilosos na base, ápice dorsalmente apiculado; estigmas laterais, voltados para a pétala posterior. Samarídeos seríceos; ala dorsal 20-27 mm compr.; núcleo seminífero com nervuras laterais conspícuas.

Ocorre na Bahia, Distrito Federal, Goiás, Mato Grosso, Mato Grosso do Sul, Minas Gerais, São Paulo e Tocantins (Amorim 2014). D2, E2/3, E5, G3: em cerrados, a cerca de $500 \mathrm{~m}$ s.n.m. Coletada com flores de abril a junho e com frutos em junho.

Material selecionado - Barreiras, 12 $09^{\prime} 00^{\prime \prime} \mathrm{S}, 4^{\circ} 59^{\prime} 24^{\prime \prime} \mathrm{W}, 11$ jun. 1992 (fl., fr.), A.M. Carvalho et al. 4069 (CEPEC, NY foto); Cocos, $14^{\circ} 15^{\prime} 00^{\prime \prime} \mathrm{S}, 4^{\circ} 43^{\prime} 56^{\prime \prime} \mathrm{W}, 9$ abr. 2005 (bot., fl.), S.F. Conceição et al. 176 (CEPEC, HUEFS); Formosa do Rio Preto,

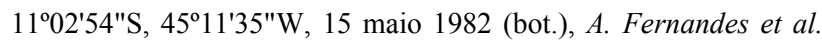

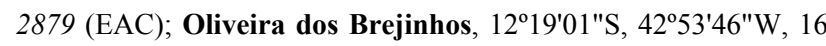
abr. 1999 (fl.), A.M. Amorim et al. 2879 (CEPEC, NY foto).

Heteropterys rhopalifolia é caracterizada pela lâmina foliar cartácea a coriácea, oval ou oboval, face abaxial esparso-tomentosa a glabrescente, com duas glândulas conspícuas impressas na base, pedicelo 5,39,3 mm compr. e estiletes geralmente pilosos na base. Assemelha-se em alguns aspectos às demais espécies de Xanthopetalis (ver comentário em $H$. aliciae), série a qual pertence. Entretanto, é facilmente diferenciada pelas características supracitadas. Heteropterys rhopalifolia não consta na lista de espécies ameaçadas da flora brasileira (Amorim et al. 2013).

35. Heteropterys rubiginosa A.Juss., Ann. Sci. Nat., Bot. II, 13: 278. 1840.

Figuras 14 e $21 \mathrm{~A}-\mathrm{E}$.

Arbusto, 1-6 $\mathrm{m}$ alt. Folhas membranáceas a cartáceas; pecíolo 2-7 $\mathrm{mm}$ compr., tomentoso, eglanduloso; lâmina 1,3-5 × 1-3 cm, oval a subcordada, base arredondada ou subcordada, ápice agudo, arredondado ou mucronado, margem revoluta; face adaxial tomentosa a glabrescente; a abaxial tomentosa, com 2-4 glândulas na base da lâmina. Corimbos 4-6(-12)-floros; brácteas 1,6-2,1 $\mathrm{mm}$ compr.; bractéolas 1,2-1,8 mm compr., elípticas a ovais; pedicelos 2,8-7,3 $\mathrm{mm}$ compr., pedunculados. Sépalas 2-2,3 × 1,7-2,2 mm, ápice plano, tomentosoferrugíneas; as laterais biglandulosas, a anterior eglandulosa. Pétalas alvas, a posterior com mácula rósea no centro, crassas, carenadas, margem erosa; as laterais sub-reflexas 3,2-4,5 × 2,1-3,1 mm; a posterior ereta a ereto-patente, limbo 3,1-3,7 × 2,2-2,9 mm. Estames desiguais; filetes glabros, 1,6-2,5 $\mathrm{mm}$ compr.; anteras glabras, eretas. Ovário tomentoso; estiletes 1-1,4 $\mathrm{mm}$ compr., retos, divergentes distalmente, os posteriores arqueados na base $e$ inclinados em direção às pétalas latero-posteriores, glabros, ápice dorsalmente arredondado ou obtuso; estigmas laterais, voltados para o centro da flor. Samarídeos tomentosos; ala dorsal 18-32 mm compr.; núcleo seminífero com cristas laterais conspícuas.
Ocorre na Bahia, Goiás, Mato Grosso, Minas Gerais, Pará, Piauí, Rondônia e Tocantins (Amorim 2014). C7, D5, D6, D7, E6, F5, F6: em campos rupestres e florestas estacionais semideciduais e deciduais, entre 500 e 1400 m s.n.m. Coletada com flores de janeiro a julho e com frutos de janeiro a julho, em setembro e outubro.

Material selecionado - Abaíra, 13º' $14^{\prime} \mathrm{S}, 4^{\circ} 39^{\prime} \mathrm{W}, 20$ abr. 1998 (fl.), L.P. Queiroz et al. 5058 (CEPEC, HUEFS, RB); Andaraí, 12 $533^{\prime} \mathrm{S}, 41^{\circ} 18^{\prime} \mathrm{W}, 21$ jan. 2010 (fl.), R.B. Santos 32 (HUEFS); Barra da Estiva, $13^{\circ} 37^{\prime} \mathrm{S}, 41^{\circ} 20^{\prime} \mathrm{W}, 19$ jul. 1981 (fr.), A.M. Giulietti et al. s.n. (CEPEC 82286); Érico Cardoso, $13^{\circ} 25^{\prime}$ S, $42^{\circ} 08^{\prime} \mathrm{W}, 26$ mar. 1980 (fl.), S. Mori \& F. Benton 13626 (CEPEC, RB); Gentio do Ouro, $11^{\circ} 24^{\prime} \mathrm{S}, 42^{\circ} 30^{\prime} \mathrm{W}, 1839$ (fr.), J.S. Blanchet 2844 (NY foto); Jacobina, 1109'15"S, 4048'33"W, 31 mar. 1996 (fl., fr.), M.L. Guedes et al. 2729 (CEPEC, HUEFS); Lençóis, $12^{\circ} 32^{\prime} \mathrm{S}, 41^{\circ} 22^{\prime} \mathrm{W}, 23$ maio 1980 (fl., fr.), R.M. Harley 22457

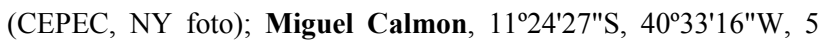
abr. 2001 (fl.), H.P. Bautista et al. 3027 (CEPEC, HUEFS); Morro

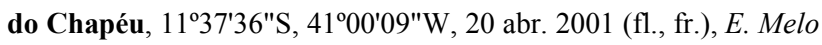
et al. 3394 (HUEFS); Mucugê, 12048'S, 4126'W, 19 jun. 2005 (fl., fr.), A.A. Conceição \& D. Cardoso 1409 (CEPEC, HUEFS); Palmeiras, $12^{\circ} 27^{\prime} \mathrm{S}, 4^{\circ} 28^{\prime} \mathrm{W}, 15$ abr. 2005 (fl.), D. Cardoso et al.

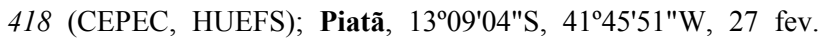
2006 (fl.), D.T. Cruz 41 (HUEFS); Rio de Contas, 1332'S, 41 ${ }^{\circ} 46^{\prime} \mathrm{W}, 21$ jul. 1979 (fr.), S.A. Mori et al. 12396 (CEPEC); Saúde, $10^{\circ} 56^{\prime} 38^{\prime \prime S}, 40^{\circ} 24^{\prime} 30^{\prime \prime W}, 14$ jul. 2004 (fl., fr.), P. Fiaschi et al. 2405 (CEPEC, RB, SP).

Heteropterys rubiginosa é caracterizada pelo indumento ferrugíneo-avermelhado na face abaxial da lâmina foliar, pétalas alvas com a posterior apresentando uma mácula rósea no centro, estigma lateral, às vezes com um aspecto subapical, e samarídeos com cristas laterais conspícuas no núcleo seminífero. Assemelha-se a $H$. campestris A.Juss., espécie típica do Cerrado no CentroOeste e Sudeste brasileiros, por apresentar indumento densamente tomentoso na face abaxial da lâmina foliar. Entretanto, a coloração do indumento e a presença de cristas laterais no núcleo seminífero dos samarídeos em $H$. rubiginosa a diferencia de $H$. campestris. Dentre as espécies da Bahia, H. rubiginosa pode ser associada morfologicamente a $H$. rufula, pela lâmina foliar oval a subcordada e presença de cristas laterais no núcleo seminífero, que são conspícuas em $H$. rubiginosa e inconspícuas em $H$. rufula. Diferem pelas características diagnósticas supracitadas para $H$. rubiginosa e também por habitarem ambientes distintos: $H$. rubiginosa ocorre em campos rupestres e florestas estacionais, enquanto $H$. rufula ocorre em floresta ombrófila submontana e restinga. Heteropterys rubiginosa pertence à série Rhodopetalis e não consta na lista de espécies ameaçadas da flora brasileira (Amorim et al. 2013).

36. Heteropterys rufula Mart. ex A.Juss., Ann. Sci. Nat., Bot. II, 13: 278.1840.

Figuras 14 e $21 \mathrm{~F}-\mathrm{I}$.

Liana, ca. $8 \mathrm{~m}$ alt. Folhas membranáceas a cartáceas; pecíolo 4,8-11,5 $\mathrm{mm}$ compr., velutino, eglanduloso; lâmina $1,7-7,7 \times 0,8-3,2 \mathrm{~cm}$, oval a 
subcordada, base obtusa, cuneada ou subcordada, ápice agudo a cuspidado, margem revoluta; face adaxial tomentosa a glabrescente; a abaxial tomentosa ou velutina, com 2 glândulas estipitadas na base da lâmina. Corimbos 3-8-floros; brácteas 0,8-1,4 $\mathrm{mm}$ compr.; bractéolas 1,4-1,8 mm compr., ovais; pedicelos 1,7-6,2 mm compr., pedunculados. Sépalas 2,8-3,1 × 1,6-1,7 $\mathrm{mm}$, ápice plano, velutinoferrugíneas, eglandulosas. Pétalas alvas com máculas róseas, crassas, carenadas; as laterais patentes a subreflexas, limbo 3,7-4 × 2-2,7 $\mathrm{mm}$, margem inteira; a posterior ereta a ereto-patente, limbo 2,6-3 × 2,3-2,7 $\mathrm{mm}$, margem inteira. Estames iguais; filetes glabros, 2,2-3,5 mm compr.; anteras glabras, eretas. Ovário velutino; estiletes 2,4-2,8 $\mathrm{mm}$ compr., curvilíneos, divergentes distalmente, os posteriores arqueados na base e inclinados em direção às pétalas lateroposteriores, glabros, ápice dorsalmente arredondados; estigmas laterais a subapicais, voltados para o centro da flor. Samarídeos velutinos; ala dorsal 17-28 mm compr.; núcleo seminífero com cristas laterais inconspícuas.

Ocorre em Alagoas, Bahia, Espírito Santo, Paraíba, Pernambuco e Rio de Janeiro (Amorim 2014). F8, G8/9, H8: em florestas ombrófilas submontanas e restingas, a cerca de 100 m s.n.m. Coletada com flores de junho a setembro e com frutos em agosto e setembro.

Material selecionado - Ilhéus, $14^{\circ} 47^{\prime} \mathrm{S}, 39^{\circ} 02^{\prime} \mathrm{W}, 16$ jul. 1991 (fl.), S.C. Sant'Ana et al. 2 (ALCB, CEPEC, HUEFS); Itacaré, $14^{\circ} 16^{\prime} \mathrm{S}, 38^{\circ} 60^{\prime} \mathrm{W}, 1$ set. 1993 (fl., fr.), A.M. Amorim et al. 1325

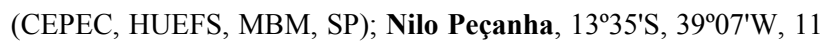
jun. 1973 (fl.), T.S. Santos 2678 (CEPEC); Una, 15²17'S, 3905'W, 15 set. 1993 (fr.), J.G. Jardim et al. 287 (CEPEC, HUEFS, MBM, SP); Wenceslau Guimarães, 13041'S, 39²9'W, 29 ago. 1991 (fl., fr.), S.C. Sant'Ana et al. 21 (CEPEC, SP).

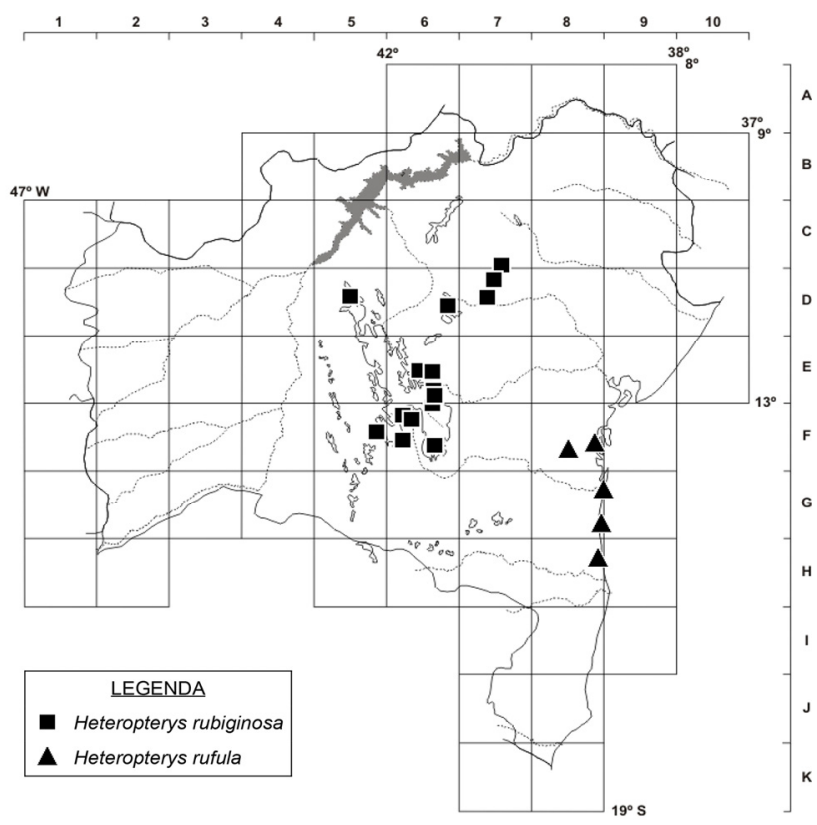

Figura 14. Mapa de distribuição de Heteropterys rubiginosa e H. rufula no estado da Bahia.
Heteropterys rufula é caracterizada pela presença de duas glândulas estipitadas na base da face abaxial da lâmina foliar, pétalas 3,7-4 $\mathrm{mm}$ compr., sépalas eglandulosas, ovário velutino, estiletes posteriores fortemente inclinados para as pétalas latero-posteriores, estigma lateral a subapical e samarídeos com nervuras laterais inconspícuas no núcleo seminífero. Assemelhase a $H$. rubiginosa (ver comentário naquela espécie), pertence à série Rhodopetalis e não consta na lista de espécies ameaçadas da flora brasileira (Amorim et al. 2013).

\section{Heteropterys sanctorum W.R.Anderson, Contr.}

Univ. Michigan Herb. 15: 130. 1982.

Figura 15; Anderson (1982: fig. 13G-M).

Liana, 3-6 $\mathrm{m}$ alt. Folhas cartáceas a coriáceas; pecíolo 14-33,5 mm compr., seríceo a glabrescente, base biglandulosa; lâmina 12,5-24 × 7,2-14,8 cm, elíptica, oval, oboval, oblonga ou lanceolada, base aguda, obtusa, arredondada, raro cuneada, ápice agudo, obtuso, cuspidado, raro retuso, margem revoluta; face adaxial glabra; a abaxial glabrescente, com 8-14 glândulas marginais ou intramarginais. Umbelas 4-6floras; brácteas 1,5-5,4 mm compr.; bractéolas 0,5-0,7 mm compr., ovais; pedicelos 8,5-9,3 mm compr, sésseis. Sépalas 2,8-3,1 × 1,3-1,8 mm, ápice plano, seríceo-castanho-claras; as laterais biglandulosas e a anterior eglandulosa, raro sépalas latero-posteriores uniglandulosas ou todas eglandulosas. Pétalas amarelas, membranáceas, margem erosa; as laterais reflexas, limbo 2,4-3,1 × 1,8-2,7 $\mathrm{mm}$; posterior reflexa, limbo 3,3-3,7 $\times 2,2-2,8 \mathrm{~mm}$. Estames desiguais; filetes glabros, 2,3-3,6 mm compr.; anteras glabras, ressupinadas. Ovário seríceo; estiletes 2,3-3,6 $\mathrm{mm}$ compr., retos, divergentes distalmente, o anterior menor que posteriores e inclinado em direção à sépala anterior, os posteriores inclinados em direção às pétalas latero-posteriores, glabros, ápice dorsalmente truncado; estigmas apicais, voltados para cima. Samarídeos seríceos a glabrescentes; ala dorsal 38-52 mm compr.; núcleo seminífero com nervuras laterais inconspícuas.

Distribuição restrita à Floresta Atlântica na Bahia (Amorim 2003a, 2014). E8, G8, H8: em florestas ombrófilas montanas e florestas estacionais semideciduais, entre 200 e 450 m s.n.m. Coletada com flores em abril, maio e julho e com frutos em outubro.

Material selecionado - Buerarema, $15^{\circ} 05^{\prime} \mathrm{S}, 39^{\circ} 19^{\prime} \mathrm{W}, 15$ out. 2003 (fr.), P. Fiaschi et al. 1694 (CEPEC); Itororó, 15²'1"S, 3949'57"W, 24 jul. 2003 (fl.), W.W. Thomas et al. 13482 (CEPEC, $\mathrm{NY}$ foto); São Felipe, $12^{\circ} 50^{\prime} \mathrm{S}, 39^{\circ} 05^{\prime} \mathrm{W}, 1$ jun. 1956 (bot.), R.P. Lordelo 56 (ALCB); São José da Vitória, 15¹7'36"S, 3904'31"W, 6 maio 1971 (fl.), T.S. Santos et al. 1603 (holótipo CEPEC); Uruçuca, $14^{\circ} 25^{\prime}$ S, $39^{\circ} 01^{\prime} \mathrm{W}, 22$ abr. 1970 (fl.), T.S. Santos et al. 761 (parátipo CEPEC).

Heteropterys sanctorum é caracterizada pela lâmina foliar grande $(12,5-24 \times 7,2-14,8 \mathrm{~cm})$, com 8-14 glândulas pequenas e marginais ou intramarginais na face abaxial, pétalas fortemente reflexas, estiletes retos e divergentes entre si distalmente, os posteriores 
inclinados em direção às pétalas latero-posteriores e o anterior inclinado em direção à sépala anterior, e estigma apical. Pertence à subseção Aptychia e além das características diagnósticas supracitadas, outra característica que a distingue das demais espécies deste grupo é a inflorescência desenvolvida em ramos basais afilos. Encontra-se criticamente ameaçada (Amorim et al. 2013) e o material Thomas et al. 13482 é seu primeiro registro em floresta estacional semidecidual.

38. Heteropterys sessilifolia A.Juss., Arch. Mus. Hist. Nat. Paris 3: 480. 1843.

Figuras 8 e 21J-O.

Arbusto ou liana, $0,5-3 \mathrm{~m}$ alt. Folhas membranáceas a cartáceas; pecíolo 0,7-1,4 $\mathrm{mm}$ compr., glabrescente, eglanduloso; lâmina 1-3,6 × 0,7$2,5 \mathrm{~cm}$, oval a cordada, base cordada, ápice arredondado, obtuso, cuspidado, margem plana; face adaxial glabra; a abaxial serícea a glabrescente, com 2 4 glândulas próximo à base da lâmina. Corimbos 4-8floros; brácteas 1,8-2,2 mm compr.; bractéolas 0,8-1,8 mm compr., oval-orbiculares; pedicelos 1,4-3 $\mathrm{mm}$ compr., pedunculados. Sépalas 2,2-3 1-1,7 mm; ápice plano; glabras com indumento pubescentes nas margens; as laterais biglandulosas e a anterior eglandulosa, ou todas biglandulosas. Pétalas róseas, crassas, carenadas, margem erosa; as laterais patentes a sub-reflexas, limbo 2,5-2,7 × 1,8-2 mm; a posterior ereta, limbo 1,7-2,3 $\times 1,4-1,7 \mathrm{~mm}$. Estames desiguais; filetes glabros, 0,4-1 mm compr.; anteras glabras, eretas a ressupinadas. Ovário seríceo; estiletes 1-2,3 $\mathrm{mm}$ compr., retos, divergentes distalmente, o anterior menor ou igual aos posteriores e inclinado em direção à sépala anterior, os posteriores arqueados na base e inclinados em direção às pétalas latero-posteriores, glabros, ápice dorsalmente arredondado a truncado; estigmas laterais, voltados para o centro da flor. Samarídeos seríceos; ala dorsal 18-26,8 mm compr.; núcleo seminífero com álulas laterais conspícuas.

Ocorre na Bahia, Ceará e Piauí (Amorim 2014). C6, D5, E6. em campo rupestre e cerrado, entre 550 a 1200 m s.n.m. Coletada com flores em outubro e dezembro e com frutos em fevereiro, março e dezembro.

Material selecionado - Barra do Mendes, $11^{\circ} 48^{\prime} 25^{\prime \prime} \mathrm{S}$,

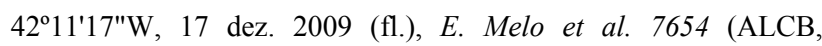

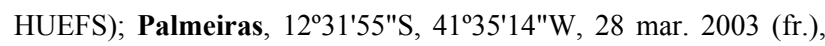

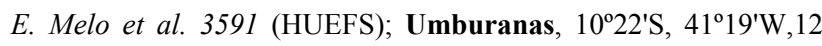
abr. 1999 (bot.), L.P. Queiroz et al. 5464 (CEPEC, HUEFS).

Heteropterys sessilifolia é caracterizada pelas folhas sésseis a subsésseis (pecíolo 0,7-1,4 $\mathrm{mm}$ compr.), lâmina foliar geralmente com base cordada, bractéolas oval-orbiculares, pétalas exclusivamente róseas e samarídeos com álulas laterais no núcleo seminífero. Dois materiais coletados no município de Palmeiras (Carvalho 302 e 394) morfologicamente semelhantes a $H$. sessilifolia, porém com pecíolo de 2 4,3 $\mathrm{mm}$ compr. (vs. 0,7-1,4 $\mathrm{mm}$ compr. em
H. sessilifolia), samarídeos com ala dorsal obliqua e fortemente curvada (vs. oblíqua e brevemente curvada) e núcleo seminífero rugoso e com cristas laterais inconspícuas (vs. álulas laterais) sugerem tratar-se de uma novidade taxonômica para o grupo. Heteropterys sessilifolia pertence à série Rhodopetalis e não consta na lista de espécies ameaçadas da flora brasileira (Amorim et al. 2013).

39. Heteropterys sincorensis W.R.Anderson, Contr. Univ. Michigan Herb. 15: 124. 1982.

Figura 13; Anderson (1982: fig. 12).

Arbusto, 3-4 m alt. Folhas coriáceas; pecíolo 1,94,3 mm compr., seríceo a glabrescente, eglanduloso; lâmina 5-10 × 4,5-6,5 cm, oval, elíptica a suborbicular, base arredondada ou cordada, ápice arredondado, apiculado ou emarginado, margem revoluta; face adaxial glabra; a abaxial glabrescente, com duas glândulas conspícuas na base e pequenas glândulas marginais. Umbelas ou corimbos 4-10floros; brácteas 1-2 mm compr.; bractéolas 1-2 mm compr., elípticas a obovais; pedicelos $5-10 \mathrm{~mm}$ compr., pedunculados. Sépalas 1,6-2 × 1,2-1,5 mm, ápice plano, seríceo-ferrugíneas; as laterais biglandulosas e a anterior eglandulosa, ou todas biglandulosas. Pétalas amarelas a laranjaavermelhadas, com faixa avermelhada na face abaxial, crassas; laterais reflexas, limbo 2-3 × 3,5-4,5 mm, margem denticulada; a posterior ereto-patente, limbo 2,2-3,1 × 3-3,4 mm, margem glanduloso-denticulada. Estames iguais; filetes glabros, 1,4-2,3 mm compr.; anteras glabras, eretas. Ovário seríceo; estiletes 1,42,1 $\mathrm{mm}$ compr., retos, eventualmente divergentes distalmente, o anterior inclinado em direção à sépala anterior, os posteriores em direção à pétala posterior, glabros, ápice dorsalmente apiculado ou truncado; estigmas laterais, voltados para o centro da flor. Samarídeos seríceos; ala dorsal 28-37 mm compr.; núcleo seminífero com nervuras laterais conspícuas.

Distribuição restrita aos campos rupestres da Bahia (Amorim 2014). C6, D7, E6, F6: entre 850 e 1150 m s.n.m. Coletada com flores de dezembro a fevereiro e abril e com frutos em fevereiro, maio e julho.

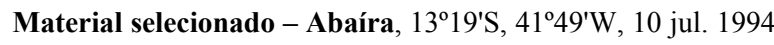
(fr.), W. Ganev 3491 (HUEFS, SP); Andaraí, 1248'26"S, 41 ${ }^{\circ} 19^{\prime} 53^{\prime \prime W}, 20$ maio 1989 (fr.), L.A.Mattos-Silva et al. 2825 (CEPEC, HUEFS, MBM, SP); Jacobina, $11^{\circ} 10^{\prime} 50^{\prime \prime} \mathrm{S}, 40^{\circ} 31^{\prime} 06^{\prime \prime} \mathrm{W}$, 23 abr. 1999 (fl.), A.M. Amorim et al. 2931 (SP); Lençóis,

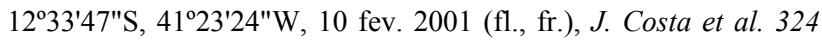

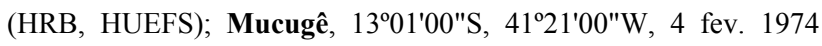
(fl.), R.M. Harley et al. 15981 (holótipo CEPEC); Palmeiras, 12³4'17"S, 4134'57"W, 19 fev. 1994 (fl., fr.), R.M. Harley et al. 14214 (CEPEC, NY foto); Rio de Contas, 133' $44^{\prime \prime S}, 41^{\circ} 48^{\prime} 41^{\prime \prime} \mathrm{W}$, 28 dez. 1997 (bot., fl.), J.G. Jardim et al. 1183 (CEPEC, MBM, NY foto); Umburanas, $10^{\circ} 24^{\prime} \mathrm{S}, 41^{\circ} 19^{\prime} \mathrm{W}, 16$ jul. 2004 (bot.), P. Fiaschi et al. 2479 (CEPEC).

Heteropterys sincorensis é caracterizada pelo hábito arbustivo, folhas apressas aos ramos, coriáceas, com duas glândulas conspícuas na base e pequenas 
glândulas marginais, sépalas com glândulas pilosas e pétala posterior com base glandulosa. Dentre as espécies que ocorrem na Bahia, compartilha características morfológicas principalmente com $H$. megaptera (ver comentário naquela espécie). Heteropterys sincorensis pertence à série Madarophyllis e não consta na lista de espécies ameaçadas da flora brasileira (Amorim et al. 2013).

40. Heteropterys syringifolia Griseb., Linnaea 13: 224. 1839.

Figuras 7, 22 e 24E, F.

Arbusto, 1,6-5 $\mathrm{m}$ alt. Folhas membranáceas a papiráceas; pecíolo 3,4-8,5 $\mathrm{mm}$ compr., tomentoso a glabrescente, eglanduloso; lâmina 3,1-6,9 × 1,3-3,5 $\mathrm{cm}$, subcordada a oval, base subcordada ou arredondada, ápice obtuso ou agudo, margem revoluta; ambas as faces tomentosas a glabrescentes; abaxial com duas glândulas no terço-médio da lâmina. Corimbos 12-floros; brácteas 0,7-1,3 mm compr.; bractéolas $0,8-0,9 \mathrm{~mm}$ compr., elípticas a ovais; pedicelos 1,9-4,3 mm compr., pedunculados. Sépalas 1,4-2,1 $\times 1,2-1,6 \mathrm{~mm}$, ápice plano, tomentosocastanhas; as laterais biglandulosas e a anterior eglandulosa, ou todas eglandulosas. Pétalas amarelas, membranáceas; as laterais patentes, limbo 2,7-3,2 $\times$ 1,7-2,1 mm, margem inteira a erosa; a posterior eretopatente, limbo 2,5-2,7 × 1,7-2,1 mm, margem erosa. Estames desiguais; filetes glabros, 1,6-2,6 $\mathrm{mm}$ compr.; anteras glabras, eretas a ressupinadas. Ovário seríceo; estiletes 2,1-2,4 $\mathrm{mm}$ de compr., divergentes distalmente, o anterior reto, os posteriores flexuosos, glabros, ápice dorsalmente apiculado ou obtusoapiculado; estigmas laterais, voltados para o centro da flor. Samarídeos seríceos; ala dorsal 12,3-23,3 mm compr.; núcleo seminífero liso.

Ocorre na Argentina e no Brasil (AL, MT, MG, PR, PE, RS, RJ, SC, SP e TO) (Amorim 2014). A ocorrência da espécie na Caatinga e Floresta Atlântica na Bahia amplia sua distribuição no Brasil. C7, C8, D7, E8, G8, H8: em caatingas e florestas estacionais semideciduais, entre 120 e 620 m s.n.m. Coletada com flores em janeiro, fevereiro, julho e novembro e com frutos em janeiro, fevereiro, abril e dezembro.

Material selecionado - Almadina, $14^{\circ} 44^{\prime} \mathrm{S}, 39^{\circ} 42^{\prime} \mathrm{W}, 9$ fev. 2000 (fl., fr.), J.G. Jardim et al. 2698 (CEPEC); Cachoeira, 12³1'59"S, 394'59"W, 5 dez. 1980 (fr.), Grupo Pedra do Cavalo 964 (ALCB, CEPEC); Cansanção, 1046'48"S, 39³4'12"W, 22 fev. 1974 (fr.), R.M. Harley et al. 16478 (CEPEC, RB); Castro alves, 1245'56"S, 39²5'42"W, 13 abr. 1995 (fr.), L.P. Queiroz \& C.A. Vidal 4324 (CEPEC, HUEFS, K foto); Feira de Santana, 12 ${ }^{\circ} 16^{\prime} \mathrm{S}$, 38 $58^{\prime} \mathrm{W}, 25$ fev. 2002 (fr.), D.L. Santana et al. 579 (ALCB, CEPEC); Gongogi, $14^{\circ} 19^{\prime} 20^{\prime \prime} \mathrm{S}, 39^{\circ} 27^{\prime} 53^{\prime \prime} \mathrm{W}, 22$ abr. 2010 (fr.), $H$. Adorno s.n. (HUEFS 183970); Itapé, 1457'50"S, 39³7'19"W, 27 out. 2004 (bot.), A.M. Amorim et al. 4320 (CEPEC); Jacobina,

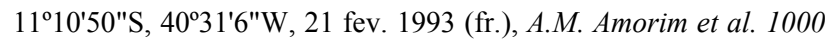
(CEPEC); Jussari, 15¹1'29"S, 39²9'43"W, 4 jan. 2000 (fl., fr.), A.M. Amorim et al. 3218 (CEPEC, UESC); Monte Santo, 10²6'S, $39^{\circ} 19^{\prime} \mathrm{W}, 11$ jan. 2006 (fr.), M.L. Guedes et al. 12097 (ALCB,
CEPEC); Palmeiras, 12³3'S, 41'34'W, 24 jul. 2007 (fl.), P.D. Carvalho \& A.A. Conceição 388 (HUEFS); Senhor do Bonfim, $10^{\circ} 22^{\prime} 48^{\prime \prime} \mathrm{S}, 40^{\circ} 10^{\prime} 12^{\prime \prime W}, 27$ fev. 1974 (fl.), R.M. Harley et al. 16508 (CEPEC, RB).

Heteropterys syringifolia é caracterizada pela presença de duas glândulas estipitadas no terço-médio da face abaxial da lâmina foliar, filetes de 1,6-2,6 mm compr. e samarídeo com núcleo seminífero diminuto, onde a ala dorsal possui porção basal reduzida e apical mais alargada. Em todos os materiais analisados, as estruturas vegetativas e florais se mostraram semelhantes a $H$. syringifolia. Entretanto, a morfologia dos frutos difere da que consta na descrição original da espécie, sugerindo que essas coleções da Bahia (e também de Pernambuco) possam ser segregadas em um novo táxon no futuro. Heteropterys syringifolia pertence à série Xanthopetalis e não consta na lista de espécies ameaçadas da flora brasileira (Amorim et al. 2013).

\section{Heteropterys trichanthera A.Juss., Ann. Sci. Nat.,}

Bot. II, 13: 273. 1840.

Figura 15; Grisebach (1858: fig. 10).

Arbusto ou liana, 1,5-5,5 $\mathrm{m}$ alt. Folhas papiráceas a cartáceas; pecíolo (3-)5,1-7,5(-9) $\mathrm{mm}$ compr., seríceo, terço-médio ou ápice biglanduloso; lâmina $(1,3-)$ 4,4-11 × $0,9-) 2,9-6,5 \mathrm{~cm}$, elíptica a oval, base subcordada a cuneada, ápice obtuso-acuminado, margem revoluta; face adaxial tomentosa a glabrescente; a abaxial tomentosa, com 2-4 glândulas marginais. Umbelas 3-5-floras ou corimbos 6-8floros; brácteas $0,8-1,6 \mathrm{~mm}$ compr.; bractéolas $0,9-$ 1,4 mm compr., ovais; pedicelos 2-6,8 mm compr., pedunculados. Sépalas 2,7-3,7 × 1,9-2,4 mm, ápice plano, seríceo-ferrugíneas; as laterais biglandulosas, a anterior eglandulosa. Pétalas amarelas, membranáceas, margem erosa; as laterais sub-reflexas a reflexas, limbo 3,8-4,1 × 2,4-3,1 mm; a posterior ereto-patente a patente, limbo 2,8-3,2 × 2,3-2,7 mm. Estames iguais; filetes glabros, 1,1-1,9 mm compr.; anteras pilosas, eretas a ressupinadas. Ovário seríceo; estiletes 2,3-2,5 $\mathrm{mm}$ compr., retos, divergentes distalmente, glabros, ápice dorsalmente apiculado ou obtuso-apiculado; estigmas laterais, voltados para a pétala posterior. Samarídeos seríceos; ala dorsal 1534,5 mm compr.; núcleo seminífero com nervuras laterais conspícuas.

Ocorre na Bahia, Ceará, Goiás, Minas Gerais, Paraíba, Pernambuco e Piauí (Amorim 2014). B5, B7, B8, B9, C6, C7, C8, C9, D2, D3, D4, D6, E3, E5, E6, E8, F3, F4, F5, F6, F7, G3, G4, G5, G6, G7: em caatingas, campos rupestres e cerrados, entre 280 e 1000 m s.n.m. Coletada com flores de dezembro a agosto e com frutos de dezembro a setembro.

Material selecionado - Antonio Gonçalves, 10³6'16"S, 40¹6'14"W, 12 mar. 2006 (fl.), E. Melo et al. 4385 (CEPEC); Aracatu, 14 $22^{\prime} 47^{\prime \prime S}, 41^{\circ} 07^{\prime} 16^{\prime \prime W}, 13$ abr. 2008 (fl.), J.G. Jardim

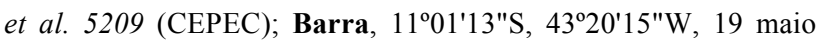
2010 (fr.), L.P. Queiroz et al. 14636 (CEPEC, HUEFS); Barro 
Alto, $11^{\circ} 45^{\prime} 11^{\prime \prime S}, 41^{\circ} 50^{\prime} 08^{\prime \prime} \mathrm{W}, 11$ abr. 2001 (fl., fr.), T.S. Nunes et al. 282 (CEPEC, HUEFS); Boa Nova, $14^{\circ} 21^{\prime} \mathrm{S}, 40^{\circ} 12^{\prime} \mathrm{W}, 7$ abr. 1988 (fr.), L.A. Mattos-Silva et al. 2349 (CEPEC, HUEFS, MBM, SP); Bom Jesus da Lapa, $13^{\circ} 15^{\prime} 05^{\prime \prime S}, 40^{\circ} 27^{\prime} 28^{\prime \prime} \mathrm{W}, 15$ maio 2001 (fl., fr.), F. França et al. 3557 (ALCB, CEPEC, HUEFS); Caculé, 14³0'42"S, 42¹1'59"W, 30 mar. 2001 (fl., fr.), J.G. Jardim et al.

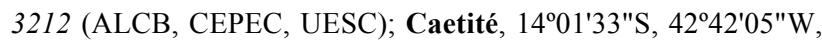
9 fev. 1997 (fl.), E. Saar et al. PCD 5316 (ALCB, CEPEC, HUEFS); Campo Formoso, 10²9'31"S, 41²0'35"W, 8 mar. 1997 (fl., fr.), A.M. Giulietti et al. PCD 6132 (ALCB, CEPEC, HUEFS); Carinhanha, $14^{\circ} 00^{\prime} 48^{\prime \prime} \mathrm{S}, 43^{\circ} 43^{\prime} 12^{\prime \prime} \mathrm{W}, 15$ abr. 2001 (fl., fr.), J.G. Jardim et al. 3503 (CEPEC, HUEFS); Cocos, $14^{\circ} 15^{\prime} 08^{\prime \prime S}, 44^{\circ} 37^{\prime} 02^{\prime \prime W}, 9$ abr. 2005 (fr.), E.B. Miranda et al. 190 (CEPEC); Contendas do Sincorá, $13^{\circ} 45^{\prime} \mathrm{S}, 41^{\circ} 02^{\prime} \mathrm{W}, 9$ abr. 1999 (fl.), A.M. Amorim et al. 2764 (ALCB, CEPEC, MBM, SP, UESC); Coribe, 14 $4^{\circ} 56^{\prime} 00^{\prime \prime} \mathrm{S}, 4^{\circ} 43^{\prime} 56^{\prime \prime} \mathrm{W}, 10$ abr. 2005 (fl.), R.M. Castro et al. 1154 (HUEFS); Curaça, 09 ${ }^{\circ} 15^{\prime} 34^{\prime \prime} \mathrm{S}, 39^{\circ} 39^{\prime} 45^{\prime \prime} \mathrm{W}$, 13 mar. 2011 (fl., fr.), E. Melo et al. 9405 (HUEFS); Feira de Santana, 12 ${ }^{\circ} 15^{\prime} 18^{\prime \prime} \mathrm{S}, 39^{\circ} 04^{\prime} 59^{\prime \prime} \mathrm{W}, 19$ ago. 2009 (fl.), E. Melo et

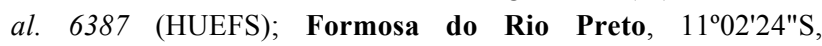
45 $15^{\prime} 43^{\prime \prime W}, 30$ mar. 2000 (fl.), E.B. Miranda et al. 349 (ALCB, CEPEC, HUEFS); Glória, 09²0'37"S, 38 $18^{\circ} 57^{\prime \prime} \mathrm{W}, 26$ abr. 2001 (bot.), L.P. Queiroz et al. 6559 (ALCB, HUEFS, UESC);

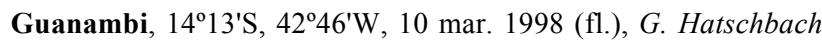
67566 (CEPEC, MBM); Iaçu, 12²45'18"S, 3951'W, 22 fev. 1997 (fl.), E. Melo et al. 2026 (CEPEC, HUEFS); Ipirá, 12 ${ }^{\circ} 10^{\prime} 45^{\prime \prime S}$, 3946'12"W, s.d. (f1.), L.P. Queiroz et al. 10606 (CEPEC 121074); Iraquara, 12 $14^{\prime} \mathrm{S}, 4^{\circ} 37^{\prime} \mathrm{W}, 14$ jun. 1981 (fr.), S.A. Mori 14432 (CEPEC); Irecê, $11^{\circ} 18^{\prime} \mathrm{S}, 41^{\circ} 51^{\prime} \mathrm{W}, 28$ abr. 1999 (fr.), A.M. Amorim et al. 3019 (CEPEC, SP); Itatim, $12^{\circ} 43^{\prime} \mathrm{S}, 39^{\circ} 42^{\prime} \mathrm{W}, 15$ mar. 1997 (fl.), V.M. Monteiro et al. 54 (CEPEC, HUEFS); Itiúba, $10^{\circ} 42^{\prime} \mathrm{S}, 39^{\circ} 50^{\prime} \mathrm{W}, 16$ jan. 1997 (fr.), M.M. Arbo et al. 7317 (CEPEC); Iuiú, 14 $17^{\prime} 11^{\prime \prime S}, 4^{\circ} 36^{\prime} 33^{\prime \prime W}, 15$ abr. 2002 (fr.),

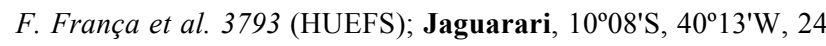
jun. 2005 (fr.), A. Rapini et al. 1208 (CEPEC, HUEFS, SP); Jequié, $13^{\circ} 52^{\prime} \mathrm{S}, 40^{\circ} 03^{\prime} \mathrm{W}, 14$ jul. 1979 (fl.), S.A. Mori 12201 (CEPEC); Jeremoabo, 1004'S, 38² $28^{\prime} \mathrm{W}, 14$ maio 1981 (f1., fr.), G.C.P. Pinto et al. 101 (CEPEC); João Dourado, $11^{\circ} 19 ' 51$ "S, 414'14"W, 14 abr. 2013 (fl., fr.), M.L.S. Guedes et al. 20667 (ALCB); Juazeiro, $09^{\circ} 24^{\prime} \mathrm{S}, 40^{\circ} 30^{\prime} \mathrm{W}, 26$ mar. 2000 (fr.), M.L.S. Guedes et al. 7304 (ALCB, CEPEC, HUEFS, UESC); Jussiape,

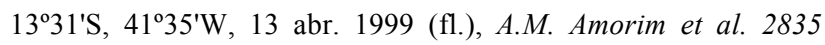
(CEPEC, SP); Macaúbas, $13^{\circ} 7{ }^{\prime} \mathrm{S}, 42^{\circ} 44^{\prime} \mathrm{W}, 7$ set. 2007 (fr.), A.A. Conceição et al. 2447 (CEPEC, HUEFS); Malhada, 14²17'11"S, 4336'39"W, 1 abr. 2001 (fl., fr.), J.G. Jardim et al. 3365 (CEPEC, HUEFS, NY foto); Maracás, $13^{\circ} 28^{\prime} 57^{\prime \prime S}, 40^{\circ} 16^{\prime} 52^{\prime \prime} \mathrm{W}, 7$ dez. 2000 (fl.), B.M. Silva 121 (HUEFS, SP); Morpará, $11^{\circ} 33^{\prime} 00^{\prime \prime S}, 43^{\circ} 16^{\prime} 00^{\prime \prime}, 22$ jan. 2001 (fl.), M.L.S. Guedes \& D. Paulo-Filho 7800 (ALCB, CEPEC, HUEFS, SP); Morro do Chapéu, $11^{\circ} 15^{\prime} 29^{\prime \prime S}, 41^{\circ} 05^{\prime} 42^{\prime \prime} \mathrm{W}, 14$ abr. 2007 (fr.), E. Melo et al. 4704 (CEPEC, HUEFS); Mucugê, $13^{\circ} 00^{\prime} \mathrm{S}, 41^{\circ} 22^{\prime} \mathrm{W}, 4$ mar. 1980 (fr.), S.A. Mori 13397 (CEPEC); Oliveira dos Brejinhos,

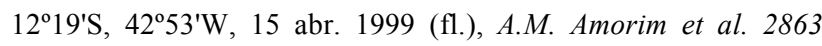
(CEPEC); Palmas de Monte Alto, $14^{\circ} 15^{\prime} 59^{\prime \prime} \mathrm{S}, 43^{\circ} 10^{\prime} 13^{\prime \prime} \mathrm{W}, 21$ abr. 2001 (fl., fr.), T.R.S. Silva et al. 140 (HUEFS); Paramirim, 13²17'50"S, 42¹4'44"W, 28 abr. 2007 (fr.), A.A. Conceição et al. 1906 (HUEFS); Paulo Afonso, 09²2'S, 3805'W, 16 jun. 2006 (fr.), M. Colaço et al. 186 (CEPEC); Pilão Arcado, 0957'59"S, 42²3'29"W, 29 fev. 2000 (fl.), A. Nascimento et al. 252 (ALCB,

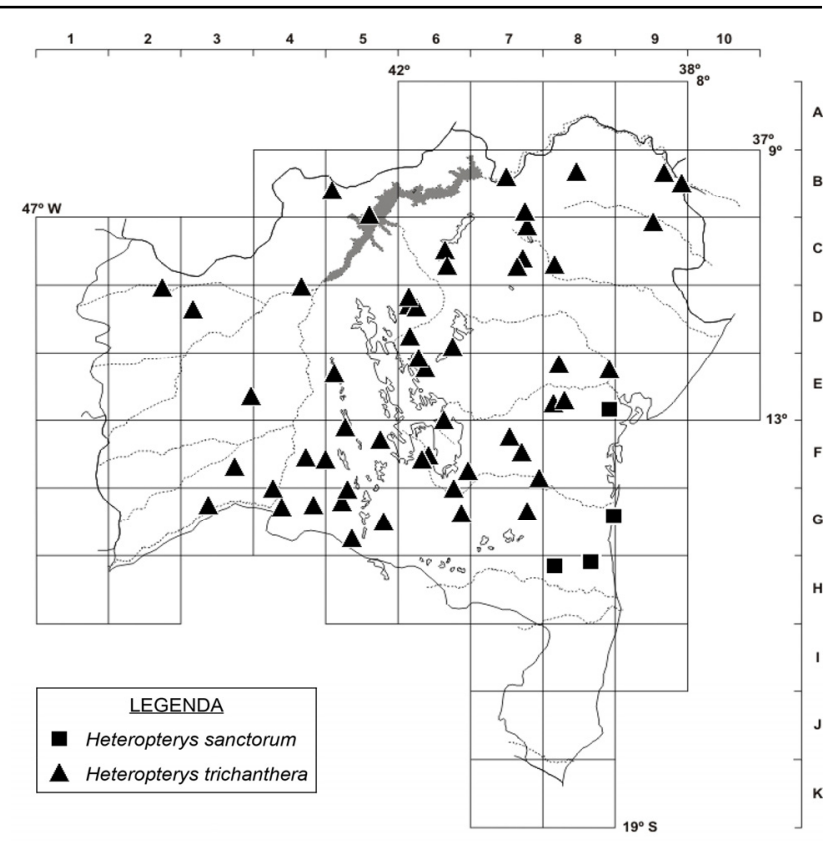

Figura 15. Mapa de distribuição de Heteropterys sanctorum e H. trichanthera no estado da Bahia.

HUEFS); Pindobaçu, 1044'S, 40²1'W, 20 dez. 1999 (fr.), M.L. Guedes et al. 7187 (ALCB, CEPEC); Remanso, 09³5'38"S, 42 54'50"W, 2 mar. 2000 (bot., fl.), M.R. Fonseca et al. 139 (ALCB, HUEFS, UESC); Riachão das Neves, $11^{\circ} 21^{\prime} 51^{\prime \prime S}$, 4450'21"W, 3 jun. 1999 (fr.), E. Melo et al. 2753 (HUEFS, UB);

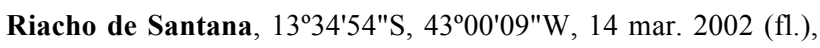
N. Roque et al. 649 (HRB, HUEFS); Rio de Contas, 13³2'S, 41 $57^{\circ} \mathrm{W}, 2$ jan. 2000 (fl.), A.M. Giulietti \& R.M. Harley 1681 (HUEFS); São Gabriel, $11^{\circ} 11^{\prime} \mathrm{S}, 41^{\circ} 51^{\prime} \mathrm{W}, 4$ jul. 2010 (fr.), R.F. Machado 563 (HUEFS); Senhor do Bonfim, 10²2'06"S, 40¹0'59"W, 17 jun. 2005 (fr.), A. Rapini et al. 1204 (CEPEC, HUEFS, SP); Serra Dourada, $12^{\circ} 39^{\prime} \mathrm{S}, 4^{\circ} 02^{\prime} \mathrm{W}, 1$ maio 1980 (fr.), R.M. Harley et al. 21998 (CEPEC); Souto Soares, $12^{\circ} 05^{\prime} \mathrm{S}$, 41ํ3'W, 15 mar. 1984 (fl., fr.), O.A. Salgado et al. 371 (CEPEC, MBM); Tanhaçu, 14\% $01^{\prime} \mathrm{S}, 41^{\circ} 14^{\prime} \mathrm{W}, 4$ fev. 1999 (fl., fr.), W.R. Anderson et al. 13722 (CEPEC); Umburanas, 1043'S, 41 ${ }^{\circ} 19^{\prime} \mathrm{W}$, 24 abr. 1999 (fr.), A.M. Amorim et al. 2947 (CEPEC, SP); Urandi, $14^{\circ} 45^{\prime} 22^{\prime \prime S}, 42^{\circ} 37^{\prime} 46^{\prime \prime W}, 6$ ago. 2009 (bot., fl.), M.L. Guedes et al. 15890 (ALCB, HUEFS).

Heteropterys trichanthera é caracterizada pelo pecíolo geralmente biglanduloso no terço-médio, lâmina foliar papirácea a cartácea, face abaxial com 24 glândulas marginais e anteras pilosas. Apesar das caracteristicas diagnósticas de fácil reconhecimento, $H$. trichanthera apresenta grande variabilidade morfológica, possivelmente determinada pela ampla distribuição geográfica em todo o Semiárido. Assemelha-se a $H$. aliciae (ver comentário naquela espécie), mas em face do isolamento geográfico de $H$. aliciae numa área de cerrado no oeste da Bahia, o reconhecimento como uma espécie distinta de $H$. trichanthera foi aqui mantido. Heteropterys trichanthera pertence à série Xanthopetalis e não consta na lista de espécies ameaçadas da flora brasileira (Amorim et al. 2013). 
42. Heteropterys trigoniifolia A.Juss., Fl. Bras. Merid. 3: 83.1833

Figuras 16 e 21P-U.

Arbusto ou liana, $1,5-2 \mathrm{~m}$ alt. Folhas membranáceas a cartáceas; pecíolo 1,5-6,7 $\mathrm{mm}$ compr., tomentoso a glabrescente, eglanduloso; lâmina 3,5-7 × 1,7-3,3 cm, lanceolada-oblonga, eliptíca, oval, suborbicular, base obtusa a arredondada, ápice agudo, apiculado ou arredondado, margem revoluta; face adaxial tomentosa; a abaxial tomentosa a glabrescente, com 2-4 glândulas intramarginais ou eglandulosa. Umbelas 4-floras ou corimbos 6-8-floros; brácteas 1,4-2,3 mm compr.; bractéolas 1-1,4 $\mathrm{mm}$ compr., ovais; pedicelos 1,7-4,8 $\mathrm{mm}$ compr., pedunculados. Sépalas $2-2,5 \times 1-1,3 \mathrm{~mm}$, ápice plano, seríceoferrugíneas; as laterais biglandulosas e a anterior eglandulosa, ou todas eglandulosas. Pétalas alvas com a posterior com listras róseas, crassas, carenadas, margem erosa; as laterais reflexas, limbo 2,3-3,6 $\times$ 1,3-2 mm; a posterior ereta, limbo 2-2,9 $\times 1,7-2,5$ $\mathrm{mm}$. Estames desiguais; filetes glabros, 1-1,9 $\mathrm{mm}$ compr.; anteras glabras, eretas a ressupinadas. Ovário seríceo; estiletes 1,3-1,9 mm compr., retos, divergentes distalmente, glabros, ápice dorsalmente apiculado ou obtuso-apiculado; estigmas laterais, voltados para o centro da flor. Samarídeos seríceos; ala dorsal 16,2$36,8 \mathrm{~mm}$ compr.; núcleo seminífero rugoso, às vezes com cristas laterais inconspícuas.

Ocorre no Espírito Santo, Mato Grosso, Minas Gerais e Rio de Janeiro (Amorim 2014). O registro dessa espécie na Bahia, amplia a distribuição conhecida da espécie. C6, C9, D6, D7, D9, E7, F5, F7: em caatingas e campos rupestres, entre 200 e $910 \mathrm{~m}$ s.n.m. Coletada com flores em janeiro, de março a maio e setembro e com frutos em março, abril, agosto e setembro.

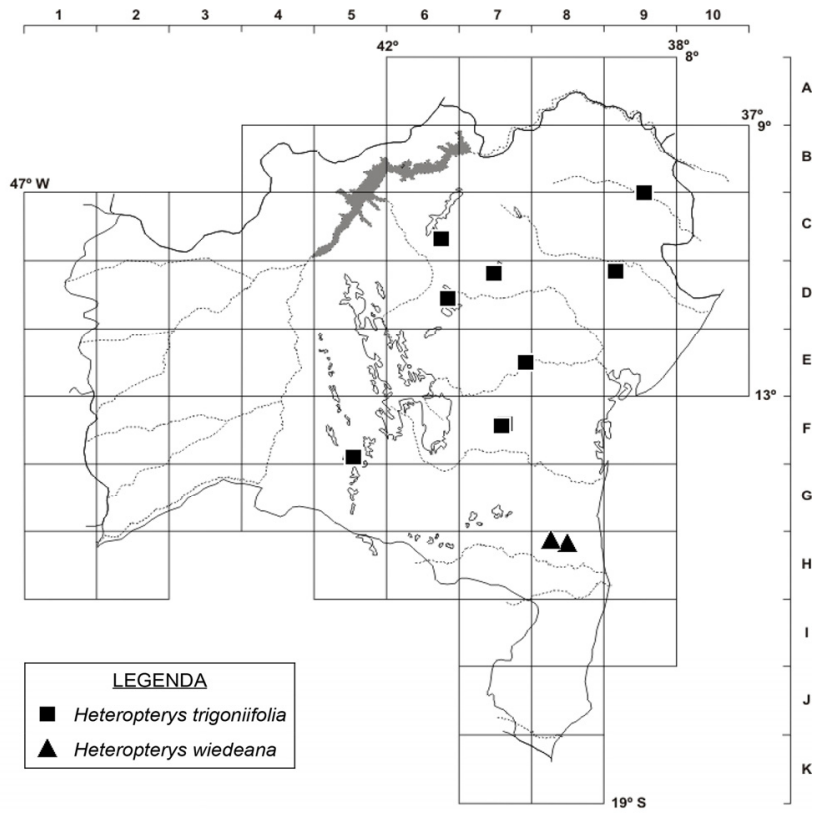

Figura 16. Mapa de distribuição de $H$. trigoniifolia e $H$. wiedeana no estado da Bahia.
Material selecionado - Caetité, 13053'10"S, 42²7'15"W, 12 abr. 2005 (fl.), E.B. Miranda et al. 795 (CEPEC, HUEFS); Itaberaba, $12^{\circ} 29^{\prime} 57^{\prime \prime S}, 40^{\circ} 04^{\prime} 56^{\prime \prime} \mathrm{W}, 5$ jun. 2005 (bot.), E. Melo et

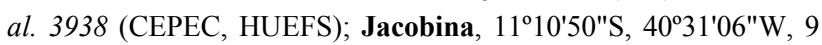
mar. 1976 (fl.), W.R. Anderson et al. 11759 (NY foto); Jequié,

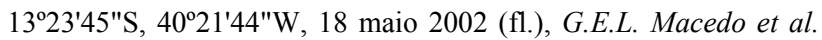
30 (HUEFS, HUESB); Jeremoabo, 1000'14"S, 38 $26^{\circ} 02^{\prime \prime} \mathrm{W}, 12$ ago. 2005 (fr.), A.Rapini et al. 1247 (CEPEC, HUEFS); Maracás,

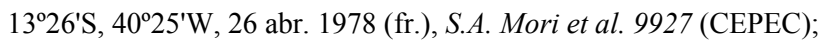

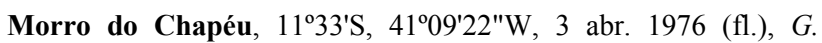
Davidse et al. 11866 (NY foto); Ourolândia, $10^{\circ} 40^{\prime} \mathrm{S}, 41^{\circ} 15^{\prime} \mathrm{W}, 9$ mar. 1976 (fl., fr.), W.R. Anderson 11754 (MO foto, NY foto), Tucano, $11^{\circ} 08^{\prime} 42^{\prime \prime} \mathrm{S}, 38^{\circ} 50^{\prime} 24^{\prime \prime} \mathrm{W}, 4$ set. 2010 (fr.), D.Cardoso \& G.Costa 3034 (CEPEC, HUEFS).

Heteropterys trigoniifolia é caraterizada pela lâmina foliar geralmente oblongo-lanceolada e anteras eretas, às vezes ressupinadas. A espécie também apresenta flores diminutas (ca. $1 \mathrm{~cm}$ diâm.) quando comparadas às demais espécies de sua série (ser. Rhodopetalis) na Bahia (ver comentário em $H$. caducibracteata). Não consta na lista de espécies ameaçadas da flora brasileira (Amorim et al. 2013).

43. Heteropterys wiedeana A.Juss., Ann. Sci. Nat., Bot. II, 13: 277. 1840.

Figura 16; Sebastiani \& Mamede (2010: fig. 12).

Liana. Folhas cartáceas a coriáceas; pecíolo 16-24 mm compr., seríceo a glabrescente, base biglandulosa; lâmina $8,6-16,5 \times 5,3-10,3 \mathrm{~cm}$, oval, base obtusa, ápice acuminado ou cuspidado, margem revoluta; ambas as faces glabras; a abaxial com 2-20 glândulas marginais. Corimbos 4-floros; brácteas 1,3-2,1 $\mathrm{mm}$ compr.; bractéolas 1,3-1,6 mm compr., elípticas; pedicelo 3,7-6 mm compr., pedunculado. Sépalas 2,4$3 \times 1,3-1,8 \mathrm{~mm}$, ápice plano, seríceo-castanhas; as laterais biglandulosas, a anterior eglandulosa. Pétalas amarelas, membranáceas; as laterais reflexas, limbo 3,5-4 × 2,5-3 mm compr., margem erosa; a posterior patente a subreflexa, limbo 3,9-4,3 × 3-3,2 $\mathrm{mm}$ compr., margem inteira. Estames desiguais; filetes glabros, 2-3,5 mm compr.; anteras glabras, eretas. Ovário seríceo; estiletes 1,8-2,2 $\mathrm{mm}$ compr., retos, divergentes distalmente, os posteriores arqueados na base, glabros, ápice dorsalmente apiculado; estigmas laterais, voltados para a pétala posterior. Samarídeos seríceos; ala dorsal 10-23 $\mathrm{mm}$ compr.; núcleo seminífero liso.

Ocorre na Bahia, Espírito Santo, Pernambuco e São Paulo (Sebastiani \& Mamede 2010; Amorim 2014). H8: em florestas estacionais semideciduais, ca. $200 \mathrm{~m}$ s.n.m. Coletada com flores em fevereiro, abril e junho e com frutos em fevereiro.

Material examinado - Itaju do Colônia, $15^{\circ} 9^{\prime} 12^{\prime \prime} \mathrm{S}$, 39 39'27"W, 4 fev. 2001 (fr.), J.G. Jardim \& F. Juchum 3174 (CEPEC, SP); Jussari, 15²1'29"S, 39²9'43"W, 22 jun. 1991 (fl.), W.W. Thomas 6828 (CEPEC, SP).

Material adicional examinado - BRASIL. ESPÍRITO SANTO: Itaguassu, 17 maio 1946 (fl.), Brade et al. 18263 (CEPEC); Santa Teresa, 13 maio 2005 (fl.), L. Kollmann \& A.P. 


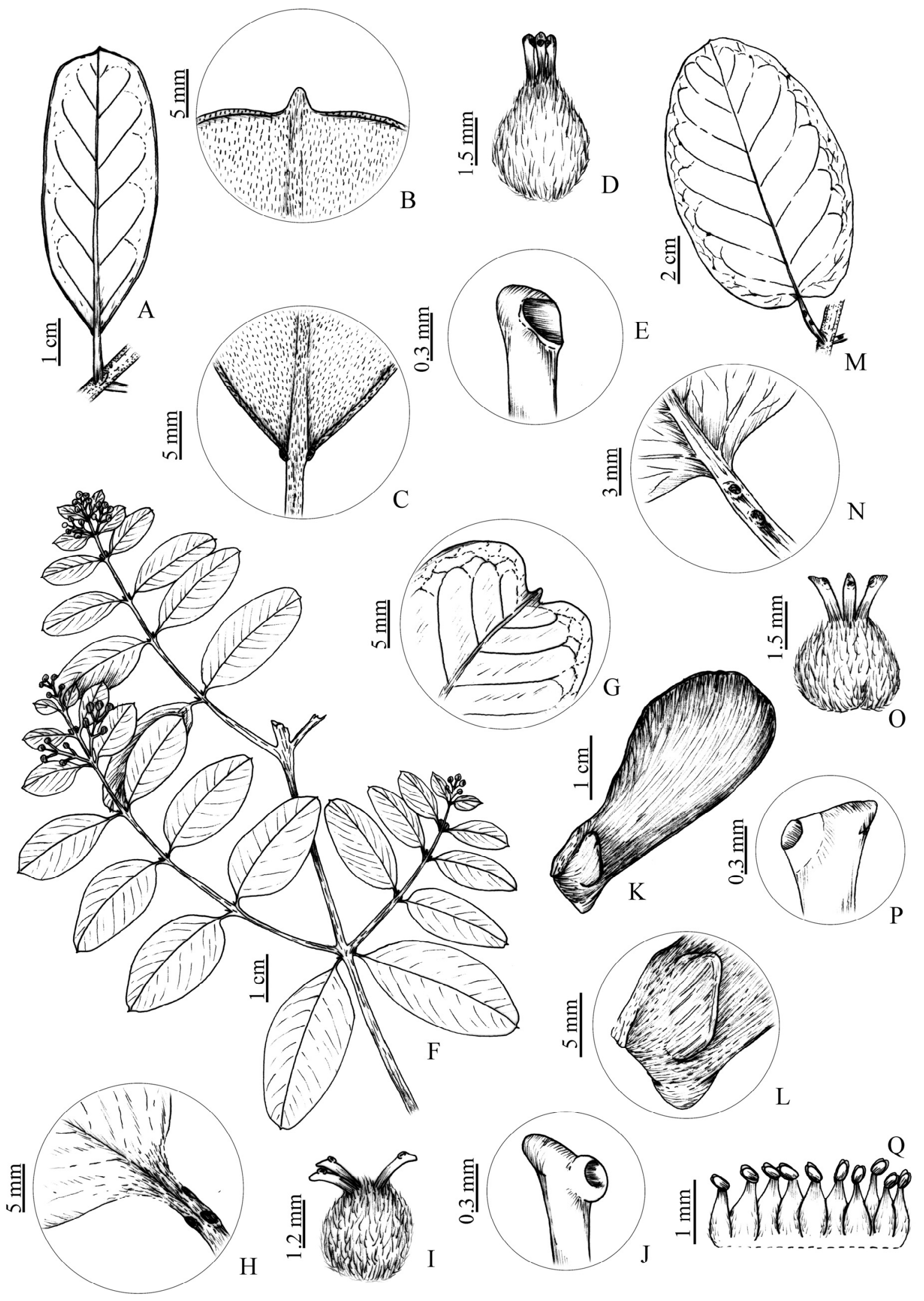

Figura 17. A-E. Heteropterys arenaria: A- folha, face abaxial; B- detalhe do ápice da lâmina foliar, face abaxial; C- detalhe da base da lâmina foliar, face abaxial; D- gineceu, com estilete anterior no centro; E- detalhe do ápice do estilete anterior. F-L. H. coleoptera: F- ramo com folhas e inflorescências; G- detalhe do ápice da lâmina foliar, face abaxial; H- detalhe das glândulas do pecíolo e da base da lâmina foliar, face abaxial; I- gineceu, com estilete anterior à direita; J- detalhe do ápice do estilete anterior; K- samarídeo; L- detalhe do núcleo seminífero do samarídeo. M-Q. H. macrostachya: M- folha, face abaxial; N- detalhe das glândulas do pecíolo e da base da lâmina foliar, face abaxial; O- gineceu, com estilete anterior no centro; P- detalhe do ápice do estilete anterior; Q- androceu, vista abaxial. (A-C- Fiaschi 2443; D, E- Melo 7617; F-H- Carvalho 1463; I, J- Amorim 1441; K, L- Jardim 2253; M, N- Amorim 2851; O-Q- Jardim 817) 


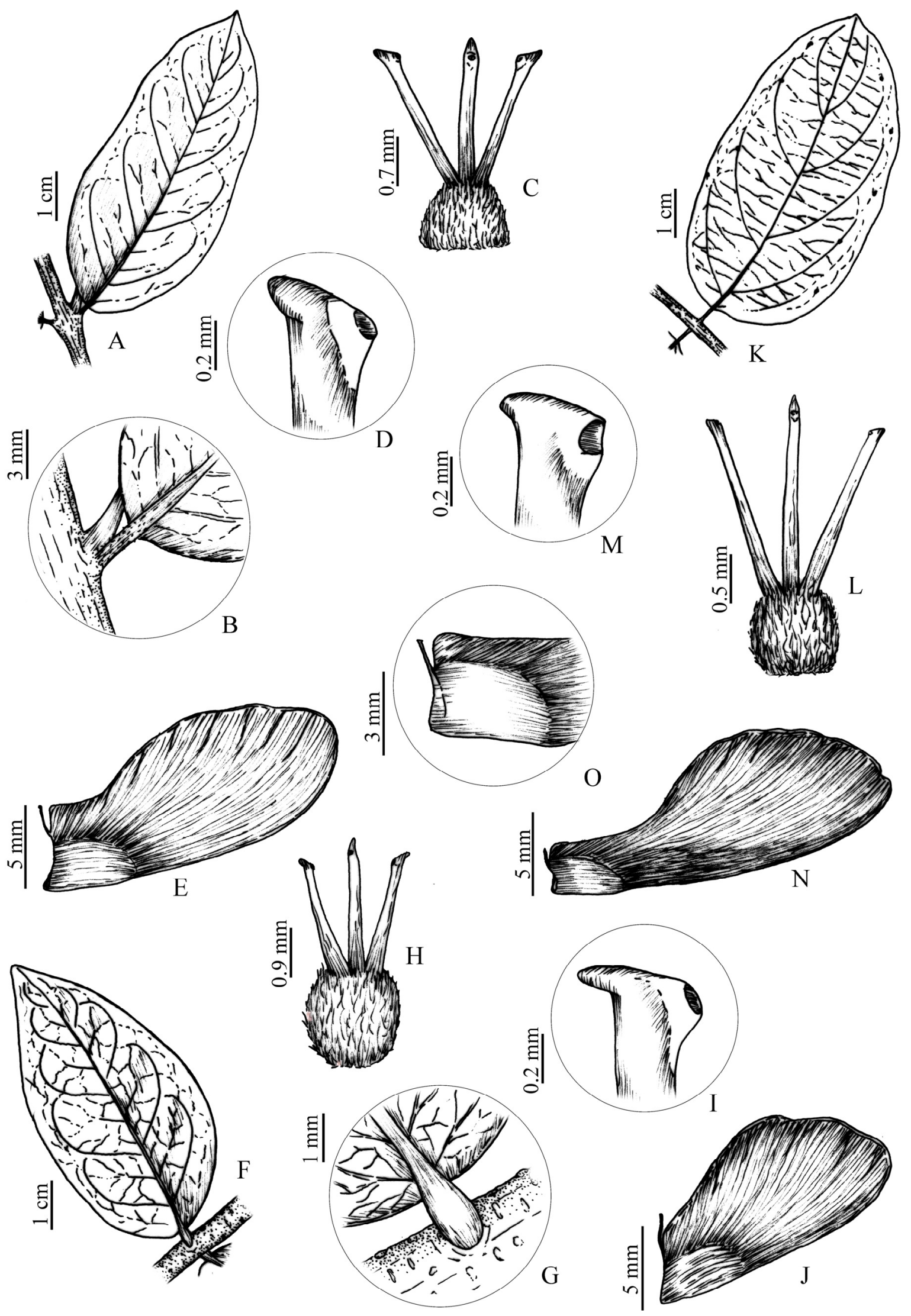

Figura 18. A-E. Heteropterys byrsonimifolia: A- ramo com folha, face abaxial; B- detalhe da base da lâmina foliar, face abaxial; C- gineceu, com estilete anterior no centro; D- detalhe do ápice do estilete anterior; E- samarídeo. F-J. H. coriacea: F- folha, face abaxial; G- detalhe do pecíolo; H- gineceu, com estilete anterior no centro; I- detalhe do ápice do estilete anterior; J- samarídeo. K-O. H. eglandulosa: K- folha, face abaxial; L- gineceu, com estilete anterior no centro; M- detalhe do ápice do estilete anterior; N- samarídeo; O- núcleo seminífero do samarídeo. (A-E- Pessoa 113; F-I- Amorim 2484; J- Amorim 2489; K-O- Melo 6847) 

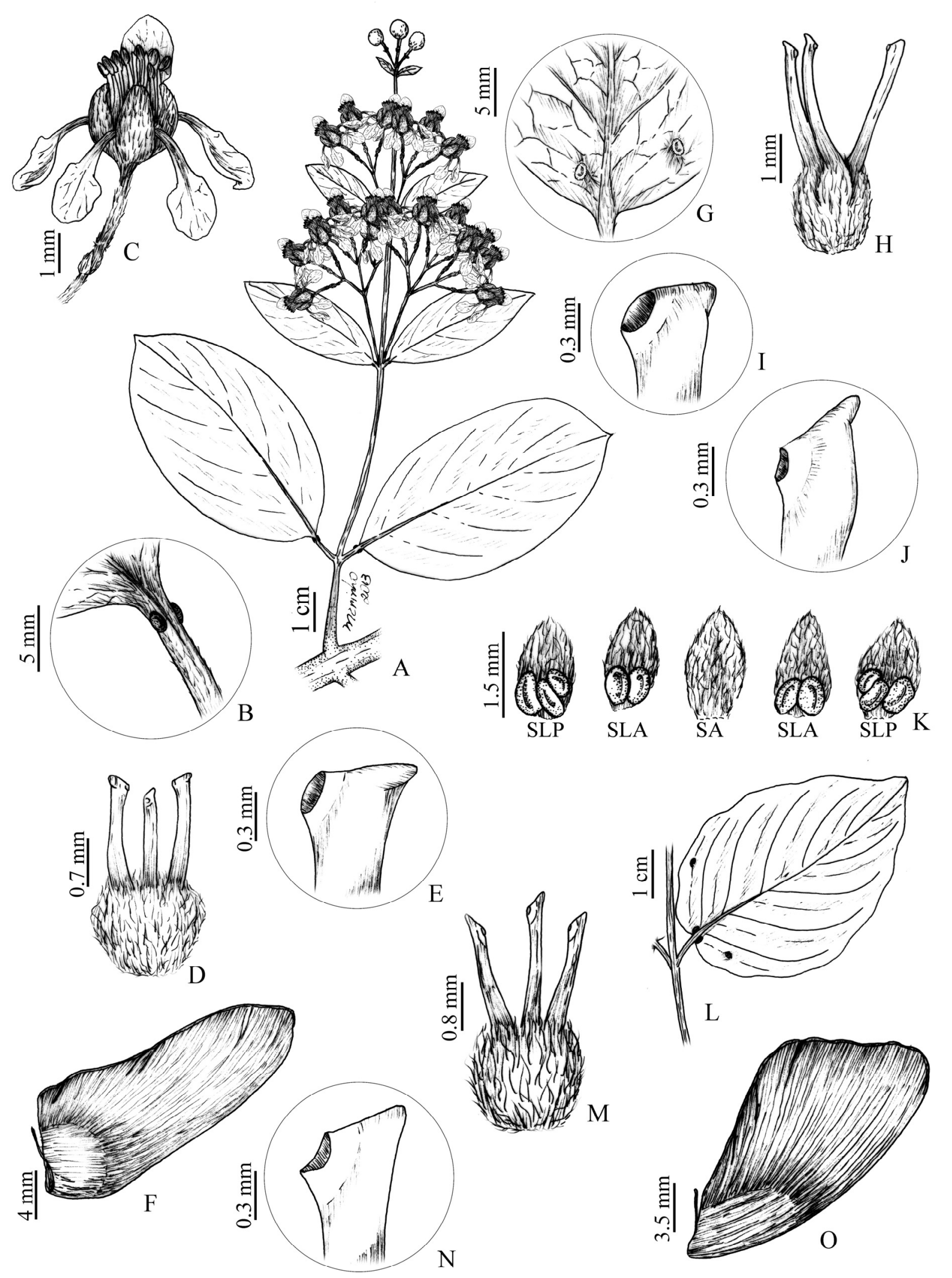

Figura 19. A-F. Heteropterys cochleosperma: A- ramo com folhas e inflorescências; B- detalhe das glândulas do pecíolo; C- flor, vista lateral, pétala posterior ereta e bractéolas abaixo do ápice do pedúnculo; D- gineceu, com estilete anterior no centro; E- detalhe do ápice do estilete anterior; F- samarídeo. G-K. H. dumetorum: G- detalhe das glândulas estipitadas na face abaxial da lâmina foliar; H- gineceu, estilete anterior à direita; I- detalhe do ápice do estilete anterior; J- detalhe do ápice do estilete posterior; K- sépalas, vista abaxial, lateroposteriores triglandulosas. (SA- sépala anterior; SLA- sépalas latero-anteriores; SLP- sépalas latero-posteriores); L-O. H. rhopalifolia: L- ramo com folha; M- gineceu, com estilete anterior no centro; N- detalhe do ápice do estilete anterior; O- samarídeo. (A-E- Jardim 3714; F- Hatschbach 62012; G- Pessoa 1; H-K-Santos 13; L-O- Carvalho 4069) 


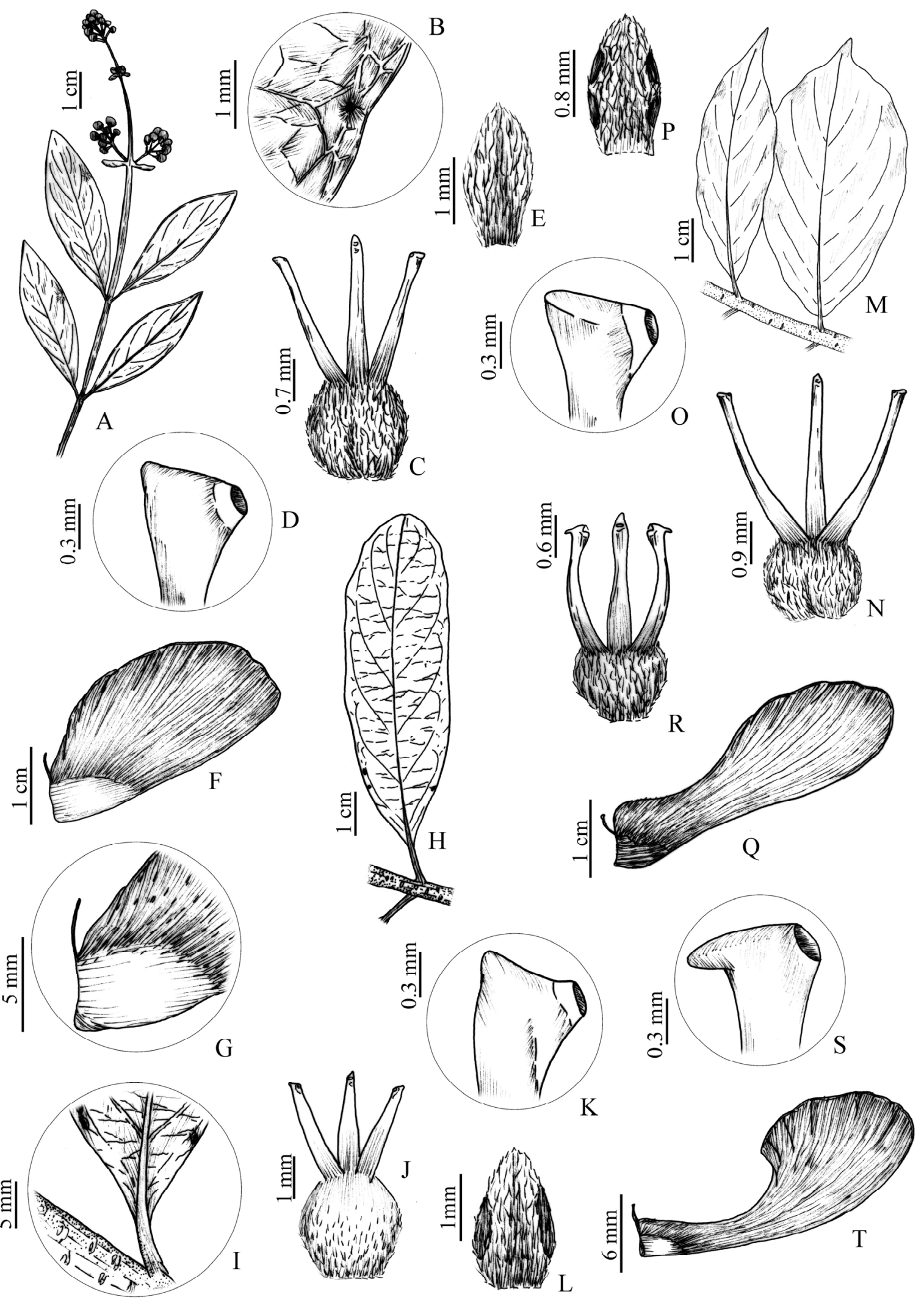

Figura 20. A-G. Heteropterys escalloniifolia: A- ramo com folhas e inflorescências; B- detalhe da glândula intramarginal na face abaxial da lâmina foliar; C- gineceu, com estilete anterior no centro; D- detalhe do ápice do estilete anterior; E- bractéola eglandulosa, face abaxial; F- samarídeo; G- núcleo seminífero do samarídeo. H-L. H. grandiflora: H- folha, face abaxial; I- detalhe do pecíolo e da base da lâmina foliar, face abaxial; J- gineceu, com estilete anterior no centro; K- detalhe do ápice do estilete anterior; L- bractéola biglandulosa, face abaxial. M-Q. H. macradena: M- ramo com folhas, face abaxial; N- gineceu, com estilete anterior no centro; $\mathbf{O}$ - detalhe do ápice do estilete anterior; P- bractéola 4-glandulosa, face abaxial; Q- samarídeo. R-T. H. nervosa: R- gineceu, com estilete anterior no centro; S- detalhe do ápice do estilete anterior; T- samarídeo. (A, B- Mori 12357; C-G- Harley 53769; H-L- Pessoa 134; M-Q- Jardim 4118; R-T- Queiroz 2107) 

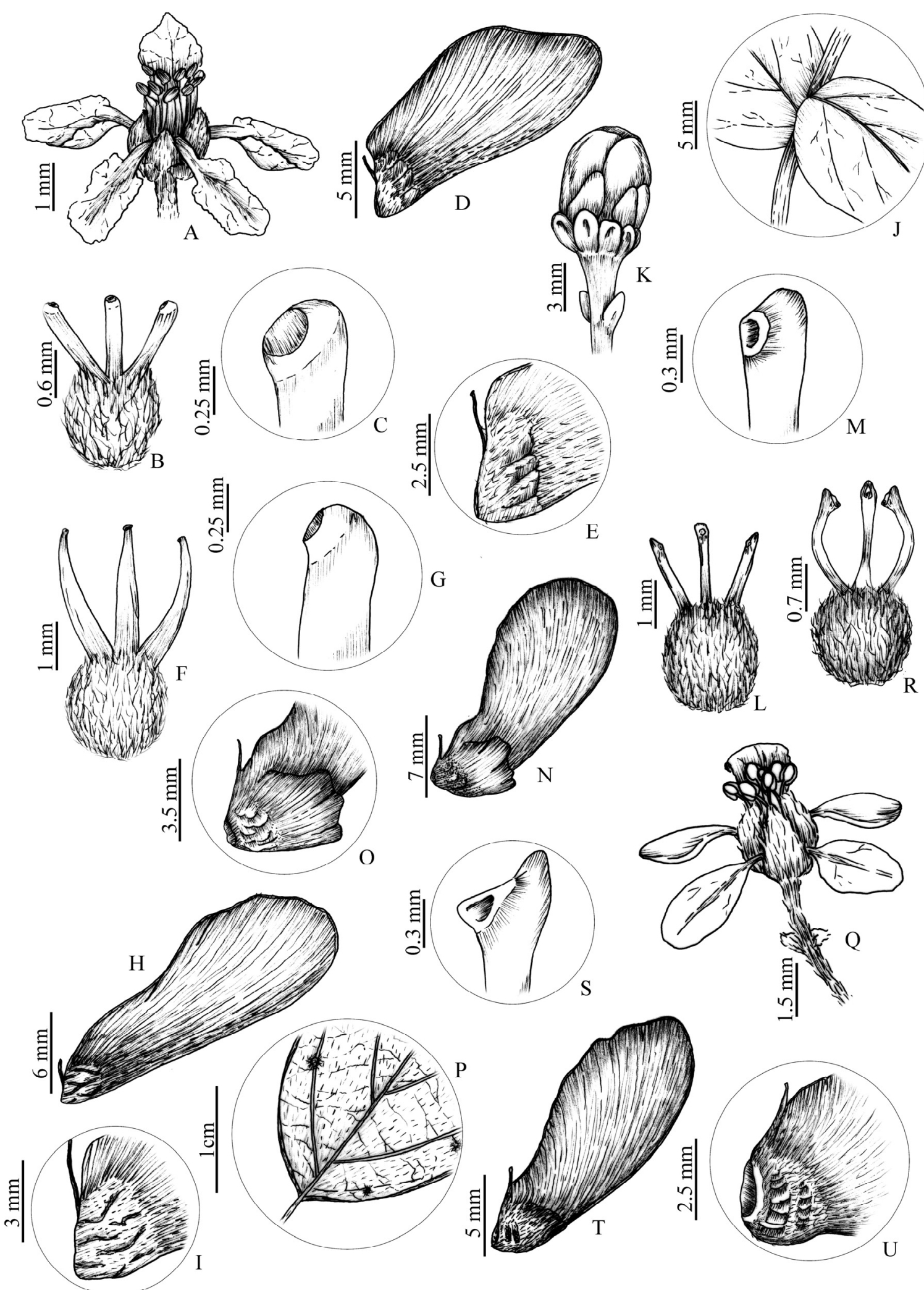

$\mathrm{O}$
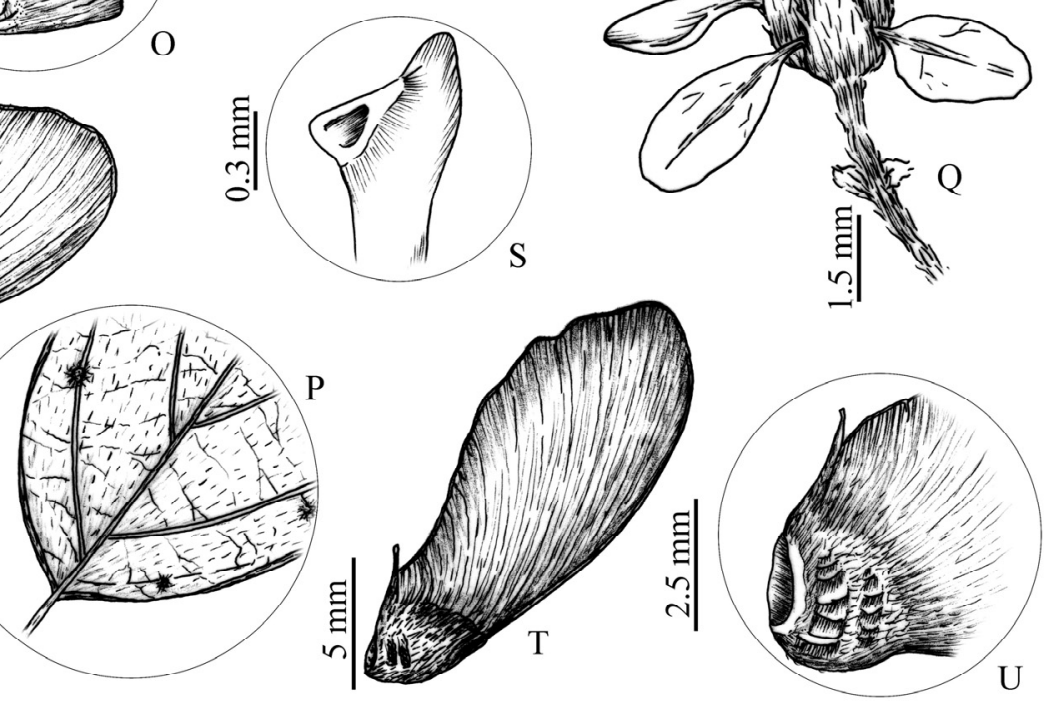

Figura 21. A-E. Heteropterys rubiginosa: A- flor, vista lateral, pétala posterior ereta; B- gineceu, com estilete anterior no centro; C- detalhe do ápice do estilete anterior; D- samarídeo; E- detalhe do núcleo seminífero do samarídeo. F-I. H. rufula: F- gineceu, com estilete anterior no centro; G- detalhe do ápice do estilete anterior; H- samarídeo; I- detalhe do núcleo seminífero do samarídeo. J-O. H. sessilifolia: J- detalhe da base da lâmina foliar, face abaxial; K- botão floral, vista lateral; L- gineceu, com estilete anterior no centro; M- detalhe do ápice do estilete anterior; N- samarídeo; O- detalhe do núcleo seminífero do samarídeo. P-U. H. trigoniifolia: P- detalhe das glândulas da face abaxial da lâmina foliar; Q- flor, vista lateral, pétala posterior ereta; R- gineceu, com estilete anterior no centro; S- detalhe do ápice do estilete anterior; T- samarídeo; U- detalhe do núcleo seminífero do samarídeo. (A-E- Harley 22457; F-I- Amorim 1325; J-M- Melo 7654; N-OMelo 3591; P-S- Miranda 795; T-U- Rapini 1247) 


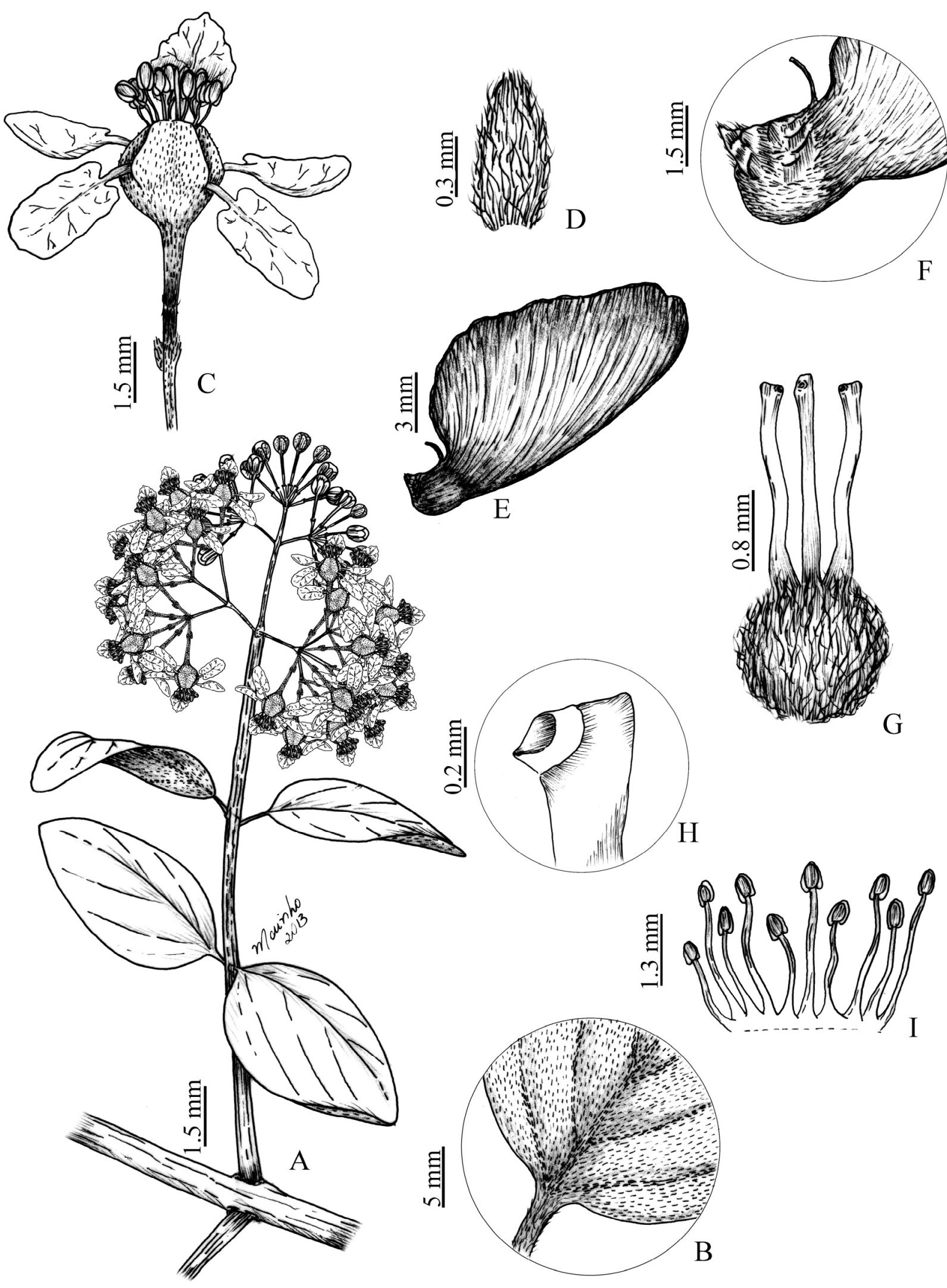

Figura 22. A-I. Heteropterys syringifolia: A- ramo com folhas e inflorescências; B- detalhe da face abaxial da lâmina foliar; C- flor, vista lateral, pétala posterior ereta; D- bractéola eglandulosa, face abaxial; E- samarídeo; F- detalhe do núcleo seminífero do samarídeo; G- gineceu, com estilete anterior no centro; H- detalhe do ápice do estilete anterior; I- androceu, vista abaxial. (Amorim 3218) 

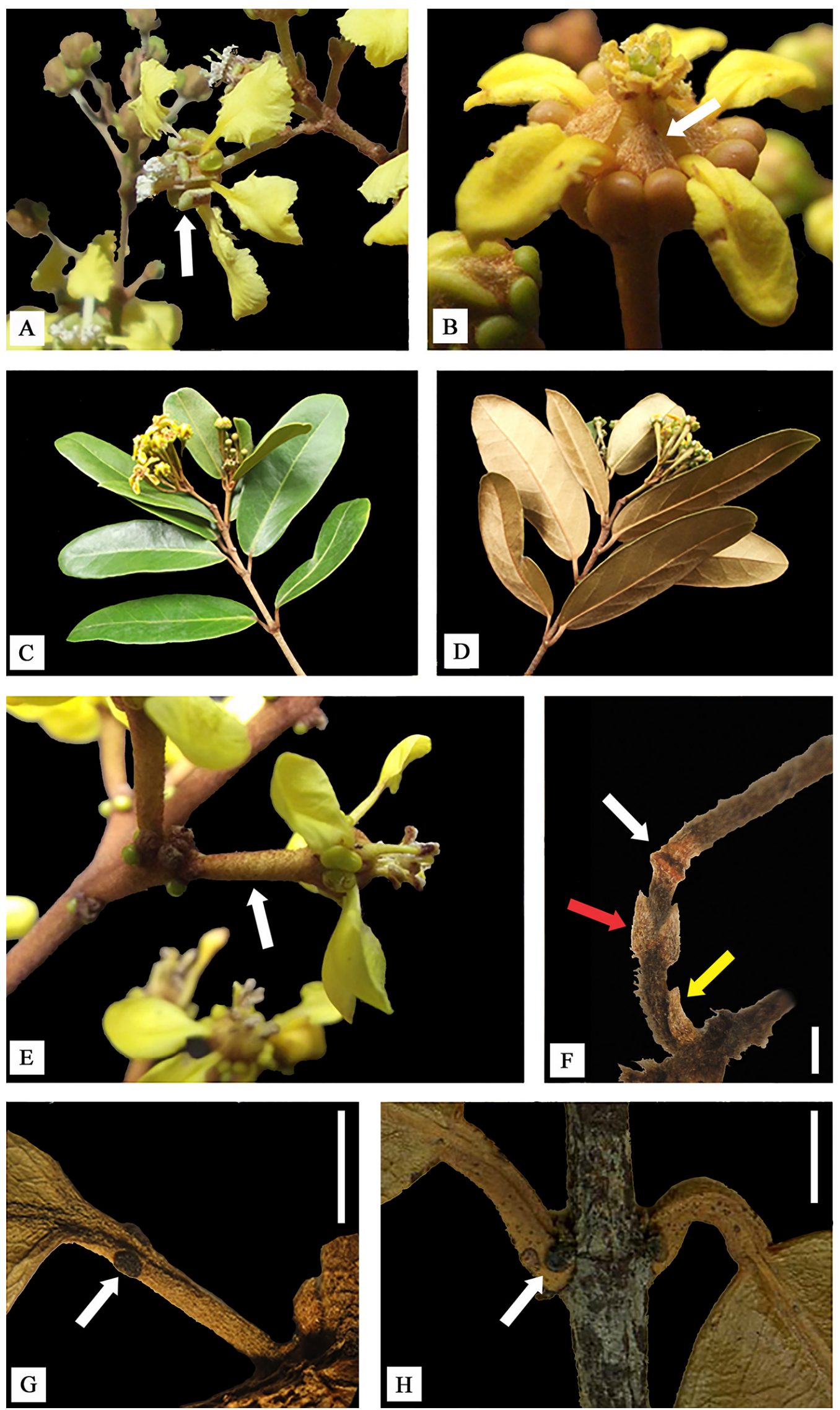

Figura 23. A. Heteropterys grandiflora: seta indicando umà sépala com ápice revoluto. B-D. H. nitida: B- seta indicando uma sépala distendida no ápice; C- coloração da face adaxial da folha; D- coloração da face abaxial da folha. E- H. oberdanii: seta indicando pedicelo séssil. F, G. H. cochleosperma: F- seta branca indicando articulação entre o pedúnculo e o pedicelo, seta vermelha indicando bractéolas inseridas abaixo do ápice do pedúnculo e seta amarela indicando uma bráctea na base do pedúnculo; G- seta indicando glândula no ápice do pecíolo. H. H. leschenaultiana: seta indicando glândula na base do pecíolo. Escalas: F- 1,5 mm; G- 1 mm; H- 0,7 mm. (Fotos: A, F, G e H- C. Pessoa; B, C-E- R. Almeida) 

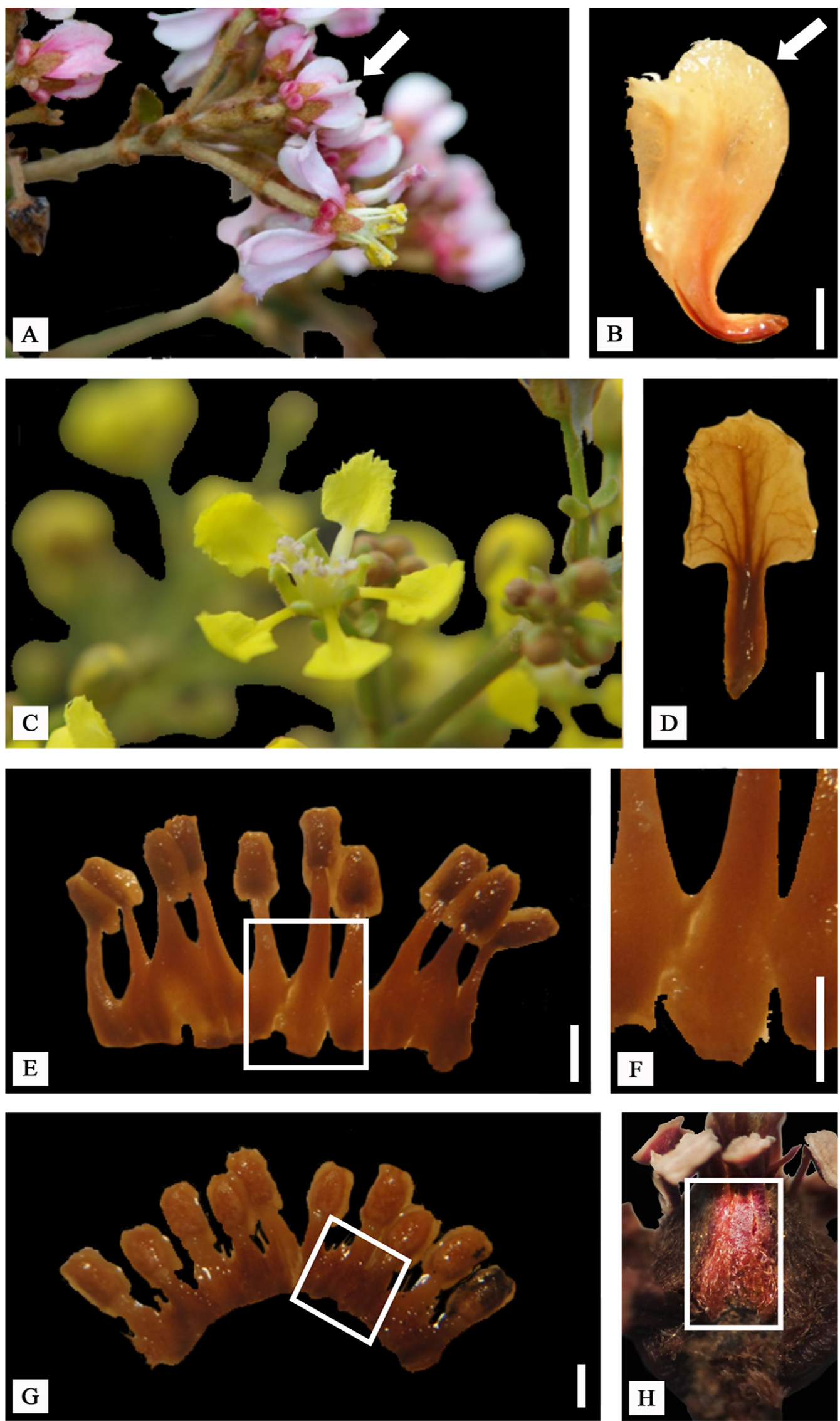

Figura 24. A e B. Heteropterys pteropetala: A- seta indicando uma pétala com carena proeminente; B- detalhe da pétala posterior com a seta indicando a carena. C, D. H. eglandulosa: C- flor com pétalas membranáceas; D- detalhe da pétala posterior membranácea. E, F. H. syringifolia: E- estames com filetes glabros na base; F- destaque para o estame oposto à sépala anterior com o filete de base glabra. G, H. H. arenaria: G- androceu com filetes pilosos na base; H- destaque para a pilosidade na base dos filetes. Escalas: B, D-G- $1 \mathrm{~mm}$; H- 0,5 mm. (Fotos: A- W.D. Stevens; B, D-H- C. Pessoa; C- A. Francener) 
Fontana 7765 (CEPEC); ib., 19 maio 1999 (est.), W.P. Lopes et al. 731 (CEPEC). PERNAMBUCO: Pesqueira, 08²1'28"S, 36 41'47"W, 4 abr. 1995 (fl.), M. Correia 150 (SP). SÃO PAULO: Tietê, 2306'00"S, 47²4'36"W, 27 abr. 1995 (fl.), L.C. Bernacci et al. 1570 (SP).

Heteropterys wiedeana é caracterizada pela lâmina foliar 8,6-16,5 × 5,3-10,3 cm, com 2-20 glândulas marginais, que dão um aspecto denticulada à margem da lâmina foliar. Heteropterys wiedeana assemelha-se a $H$. leschenaultiana (ver comentário naquela espécie). $\mathrm{O}$ material Thomas et al. 6828 e 12199 mostram semelhanças morfológicas com $H$. leschenaultiana, dificultando a separação dessas espécies (Sebastiani \& Mamede 2010). Heteropterys wiedeana pertence à subseção Stenophyllarion e não consta na lista de espécies ameaçadas da flora brasileira (Amorim et al. 2013).

\section{Agradecimentos}

Os autores agradecem à FAPESB pelo apoio ao Projeto Flora da Bahia; à CAPES pela bolsa de mestrado concedida a $\mathrm{CP}$; ao $\mathrm{CNPq}$ pelo financiamento deste trabalho através do Edital REFLORA Malpighiales (processo $\left.n^{\circ} 563548 / 2010-0\right)$ e pela bolsa de produtividade (processo $n$ o 306992/2012-4), conferida a AMA; à UEFS e ao CEPEC pela infraestrutura disponibilizada. Agradecemos também ao biólogo Lucas Marinho pelas ilustrações e à Dra. Nadia Roque e Dra. Lydiane Aona pelas contribuições ao manuscrito durante o processo de análise da Dissertação.

\section{REFERÊNCIAS}

Amorim, A.M. 1994. Malpighiaceae da Reserva Ecológica de Macaé de Cima, Nova Friburgo, Rio de Janeiro, Brasil. In: M.P.M. Lima \& R.R. Guedes-Bruni (orgs), Reserva Ecológica de Macaé de Cima: Nova Friburgo - RJ: aspectos florísticos das espécies vasculares. Vol. 1. Jardim Botânico do Rio de Janeiro, Rio de Janeiro, p. 229-249.

Amorim, A.M. 2002. Five new species of Heteropterys (Malpighiaceae) from Central and South America. Brittonia 54(4): 217-232.

Amorim, A.M. 2003a. Estudos Taxonômicos em Heteropterys (Malpighiaceae). Tese de Doutorado, Universidade de São Paulo, São Paulo. 286.

Amorim, A.M. 2003b. The anomalous-stemmed species of Heteropterys subsect. Aptychia (Malpighiaceae). Brittonia 55: $127-145$.

Amorim, A.M. 2004. A new species of Heteropterys (Malpighiaceae) from the semideciduous forests of Bahia, Brazil. Brittonia 56: 143-146.

Amorim, A.M. 2005. Heteropterys jardimii (Malpighiaceae), uma nova espécie para a Bahia, Brasil. Rodriguésia 56(87): 175-178.

Amorim, A.M. 2014. Heteropterys. In: Lista de Espécies da Flora do Brasil. Jardim Botânico do Rio de Janeiro. Disponível em
http://floradobrasil.jbrj.gov.br/jabot/floradobrasil/FB8865/; acesso em 25 jul. 2014.

Amorim, A.M. \& São-Mateus, W.M.B. 2009. Redescrição de Heteropterys bahiensis Nied. (Malpighiaceae). Rodriguésia 60(2): 367-370.

Amorim, A.M.; Kutschenko, D.C.; Judice, D.M. \& Barros, F.S.M. 2013. Malpighiaceae. In: G. Martinelli \& M.A. Moraes (orgs), Livro Vermelho da Flora do Brasil. Vol. 1. Instituto de Pesquisas Jardim Botânico do Rio de Janeiro, Rio de Janeiro, p. 648-654.

Anderson, W.R. 1979. Floral conservatism in Neotropical Malpighiaceae. Biotropica 11:219-223.

Anderson, W.R. 1981. Malpighiaceae. In: B. Maguire (ed.), The Botany of the Guayana Highland - Part XI. Memoirs of the New York Botanical Garden 32: 21-305.

Anderson, W.R. 1982. Notes on Neotropical Malpighiaceae - I. Contributions from the University of Michigan Herbarium 15: 93-136.

Anderson, W.R. 1987. Notes on Neotropical Malpighiaceae - II. Contributions from the University of Michigan Herbarium 16: 55-108.

Anderson, W.R. 1993. Notes on Neotropical Malpighiaceae - IV. Contributions from the University of Michigan Herbarium 19: 355-392.

Anderson, W.R. 1997. Malpighiaceae. In: J. Boggan, V.A. Funk, C.L. Kelloff, M. Hoff, G. Cremers \& C. Feuillet (eds), Checklist of the Plants of the Guianas (Guyana, Surinam, French Guiana). 2 ed. Biological Diversity of the Guianas Program, Department of Botany, National Museum of Natural History, Smithsonian Institution, Washington, D.C., p. 127-128.

Anderson, W.R. 2013. Origins of Mexican Malpighiaceae. Acta Botanica Mexicana 104: 107-156.

Anderson, W.R.; Anderson, C. \& Davis, C.C. 2006. Malpighiaceae. Disponível em http://herbarium.lsa.umich.edu/ malpigh/index.html/; acesso em 11 jul. 2014.

Carvalho, P.D.; Rapini, A. \& Conceição, A.A. 2010. Flora da Bahia: Malpighiaceae: Banisteriopsis, Browenia e Diplopterys. Sitientibus Série Ciêcnias Biológicas 10(1): 158-191.

Curtis, F.L.S. 1833. Heteropterys chrysophylla. In: F.L.S. Curtis \& L.L.D. William (orgs), The Botanical Magazine or Flower Gardem Displayed. Vol. 60 [sér. 2, vol. 7]. London, p. 3237.

Davis, C.C. \& Anderson, W.R. 2010. A complete generic phylogeny of Malpighiaceae inferred from nucleotide sequence data and morphology. American Journal of Botany 97: 2031-2048.

Funk, V.A.; Berry, P.E.; Alexander, S.; Hollowell, T.H. \& Kelloff, C.L. 2007. Checklist of the Plants of the Guiana Shield (Venezuela: Amazonas, Bolivar, Delta Amacuro; Guyana, Surinam, French Guiana). Contributions from the University of Michigan Herbarium 55: 1-584.

Grisebach, A.H.R. 1858. Malpighiaceae. In: C.F.P. Martius, A.G. Eichler \& I. Urban (eds), Flora Brasiliensis. Vol. 12, pt.1. Typographia Regia, Monachii, p. 1-123, t. 1-22.

Jussieu, A. 1840. Malpighiacearum synopsis, monographiae mox edendae prodromus. Annales des Sciences Naturelles, Botanique, ser. 2, 13: 247-291; 321-338.

Mamede, M.C.H. 2004. Flora de Grão-Mogol, Minas Gerais: Malpighiaceae. Boletim Botânica da Universidade de São Paulo 22(2): 291-302. 
Mamede, M.C.H.; Amorim, A.M.; Sebastiani, R; Almeida, R.F. \& Francener, A. 2014. Malpighiaceae. In: Lista de Espécies da Flora do Brasil. Jardim Botânico do Rio de Janeiro. Disponível em http://floradobrasil.jbrj.gov.br/jabot/floradobrasil/FB155/; acesso em 18 jul. 2014.

Moricand, M.E. 1840. Plantes Nouveles d'Amérique. Genève, p. 108, pl. 66.
Niedenzu, F. 1928. Malpighiaceae - Heteropterys. In: A. Engler (ed.), Das Pflanzenreich. Vol. 4(141), pt 91, 93, 94. Verlag von Wilhelm Engelmann, Leipizig.

Sebastiani, R. \& Mamede, M.C.H. 2010. Estudos taxonômicos em Heteropterys subsect. Stenophyllarion (Malpighiaceae). Hoehnea 37: 337-366.

\section{LISTA DE EXSICATAS}

Abreu, I.S. 43 (20); Adorno, H. s. n. HUEFS 183970 (40); Almeida, G.O. 454 (16), 475 (34), 583, 646 (17), 725 (28); Almeida, J. 364 (14); Almeida, L.S. 8 (29); Alves, L.J. 5, 152 (21); Amorim, A.M. 397 (21), 659 (15), 1000 (40), 1051 (13), 1302 (30), 1325 (36), 1340 (24), 1372 (36), 1398 (21), 1441 (13), 1811 (42), 2199 (30), 2485 (18), 2484, 2489 (16), 2549, 2573 (11), 2604 (40), 2710 (5), 2764,2765 (41), 2773 (39), 2793 (35), 2835, 2837, 2863 (41), 2851 (26), 2865 (41), 2879 (34), 2883 (30), 2931 (39), 2933 (35), 2944, 2947,3019 (41), 3062 (18), 3087 (15), 3090 (24), 3095 (15), 3218 (40), 3223 (3), 3224, 3225 (22), 3227 (15), 3329 (24), 3346 (31), 3372 (24), 3417 (15), 3433 (30), 3435 (15), 3551 (7), 3583 (14), 3642 (3), 3653 (37), 3663 (8), 3671 (26), 3696 (21), 3898, 3900 (25), 3981 (7), 4009 (19), 4105 (29), 4131 (5), 4320 (40), 4346 (20), 4386 (15), 4389 (29), 4452 (7), 4745 (22), 4922 (21), 4952 (30), 5044 (7), 5291,5396 (29), 5506 (24), 5732 (29), 6283 (24), 6662 (29), 6693, 6735 (7), 6977 (29), 7013 (7), 7450 (30), 8256 (6); Anderson, W.R. 9430 (12), 11742 (9), 11746 (20), 11754 (42), 11759 (42), 13722 (41), 36836 (32), 37073 (19), 37119 (1); Araújo, G. 302 (28), 335 (28); Araújo, T. 209 (6); Arbo, M.M. 7317 (41), 7460 (4); Arzolla, F.A.R.D.P. 452 (24); Atkins, S. PCD 4823, s.n CEPEC: 74865, 96971 (39); Bautista, H.P. 893 (41), 3027 (35), 4174 (16); Belem, R.P. 2257 (30), 2781 (2), 3846 (24); Bernacci, L.C. 1570 (43); Blanchet, J.S. 2844 (35), 3265 (10); Borba, E.L. 1962 (35); Brandão, G.S. 344 (27), 142 (6), 250 (26); Brito, M.J.S. 1 (30); Cardoso, D. 336 (32), 418 (35), 730 (32), 848 (8), 1264 (11), 1593, 1611, 2262 (23), 2340 (21), 3034 (42); Carneiro-Torres, D.S. 538 (8), 644 (9); Carvalho, A.M. 213, 692 (2), PCD 956 (21), 1463 (13), 3393 (15), 3394 (30), 3559 (21), 3565 (13), 3730 (4), 4022 (16), 4069 (34), 6028, 6043 (15); 6206 (27), 6811 (24), 6977 (26); Carvalho, D.N. 41, 201 (6); Carvalho, P.D. 86, 90 (35), 126 (32), 302 (44), 323 (19), 365 (8), 356 (8), 374 (28), 388 (40), 394 (44); Carvalho, G.M. 194 (21); Carvalho-Sobrinho, J.G. 342 (30), 553 (42), 2548 (4); Castro, R.M. 1154 (41); Chautems, A. 197 (20); Colaço, M. 186 (41); Colman, L.P. 26 (13), 31 (21), 32 (15); Conceição, A.A. 1409 (35), 1438 (20), 1604 (8), 1721 (28), 1895 (41), 1906 (41), 2129 (8), 2447 (41), 2526 (8), 2559 (20), 2609 (35), 2787, 2810 (8); Conceição, S.F. 176 (34), 210 (42); Correia, C. 409 (9); Correia, M. 150 (43); Costa, A.L. 232, s.n. ALCB 19495 (2); Costa, G. 478 (33); Costa, J. 324 (39); Cruz, D.T. 41 (35); Daneu, L. 127 (7), 245 (29); Davidse, G. 11866 (42); Duarte, A.P. s.n. (RB 60840) (27); Eupunino, A. 145 (2); 268, 299 (21), 330 (2); Fernandes, A. 2879 (34); Ferreira, F.M. 1293 (29), 1877 (26); Ferreira, J.L. 28 (4); Ferreira, M.C. 725 (21); Ferrucci, M.S. 958 (24), 1007 (8); Fiaschi, P. 608 (24), 1379 (23), 1441 (31), 1694 (37), 1932 (26), 2276 (15), 2405 (35), 2423 (32), 2443 (4), 2479 (39), 2559 (21), 2773 (3); Folli, D.A. 3896 (31), 5279 (27), 5510 (31); Fonseca, M. 1105 (30); Fonseca, M.R. 139 (41); França, F. 1394 (11), 1447 (6), 1612 (41), 1689 (8), 1872 (11), 2135 (32), 2343 (11), 2435 (20), 2478 (33), 3130 (35), 3557 (41), 3589 (34), 3790, 3793, 3860 (41), 4167 (4), 4270 (33), 4901 (10); Furlan, A. s. n. (CEPEC 82276) (39); Ganev, W. 805 (19), 946 (19), 1354 (8), 1422 (4), 1782 (33), 2012 (19), 2169 (8), 2350 (13), 2716 (4), 2770 (33), 2784 (19), 3014 (35), 3217 (35), 3458 (4), 3491 (39), s.n. HUEFS 13693 (19); Gentle, P.H. 6034 (26); Gentry, A.H. 50142 (38); Ginzbarg, S. 839 (42); Giulietti, A.M. 1503 (19), 1635 (39), 1646 (32), 1681 (41), 1863 (32), 1899 (39), PCD 2695 (20), PCD 6132 (41), s.n. (CEPEC 82286) (35); Gomes, F.S. 192, 382 (8); Gonçalves, R.S. 25 (32); Gouvêia, E. s.n. ALCB: 20634, 21617 (18); Guedes, M.L. PCD 764 (21), 1474 (18), 2531 (2), 2729 (35), 3777 (5), PCD 4970 (33), 5302 (9), 5393 (20), 5615 (39), 6408 (19), 7187 (41), 7304 (41), 7312 (41), 7800 (41), 9443 (21), 10259 (31), 10281 (35), 10865 (9), 11630 (41), 11780 (33), 12097 (40), 12784 (8), 13390 (16), 13548 (41), 13563 (28), 13882 (28), 13990 (20), 13939 (41), 14029 (20), 14106 (20), 14351 (4), 14500 (8), 14684 (33), 14828 (39), 15145 (13), 15890 (41), 16035, 16117 (8), 17117 (33), 17814, 19380 (21), 20667 (41), s.n. ALCB 20208 (30), s.n. ALCB 21358 (2), s.n. ALCB 27480 (13); Hage, J.L. 330, 1051, 1096, 1203, 1207, 1306, 1489 (24); Harley, R.M. 3300 (35), PCD 3644, 14214, 15981 (39), 16313 (41), 16478, 16508 (40), 16775 (32), 17243, 17807 (2), 18352 (13), 18587 (39), 18613 (20), 19631 (35), 20632 (18), 21019 (39), 21998 (41), 22457 (35), 24145, 24304 (33), 25607 (8), 25959 (18), 27412, 28258, 28392 (8), 28623 (32), 53769 (19), 54433 (8), 54455 (41), 54661 (19), 54880 (10), 56121 (19), 56153 (8); Hatschbach, G. 39081 (16), 39443 (33), 42291 (16), 44176 (28), 47467 (39), 47994 (9), 48309 (16), 49474 (24), 55124 (32), 56832 (41), 62012 (12), 67566 (41), Hind, N. PCD 4263 (18); Hurbath, F. 70 (18); Irwin, H.S. 7261 (17), s.n. NY 17502 (12), 31564 (33); Jardim, A.B. 173 (29); Jardim, J.G. 106 (30), 249 (21), 287 (36), 388 (30), 406 (15), 501 (36), 817 (26), 867,873 (24), 945 (16), 1183 (39), 1560 (13), 1883 (5), 2253 (13), 2530 (21), 2571 (33), 2697 (22), 2698 (40), 2828 (23), 3049 (7), 3076 (15), 3141 (3), 3174 (43), 3177 (3), 3178 (14), 3191 (29), 3212 (41), 3338 (4), 3350, 3365, 3423 (41), 3440 (7), 3503 (41), 3705 (18), 3714 (12), 3952 (15), 3978 (5), 3999 (21), 4009 (35), 4118, 4123 (25), 4338 (29), 4355 (7), 4621 (24), 4858 (7), 5209 (41); Jesus, N.G. 882 (10), 1329 (39), 2025 (18); Jost, T. 97, 285 (21); Junqueira, M.E.R. 64 (35); Kollmann, L. 6517 (22), 7765 (43); Lima, S.S. 45 (30); Lombardi, J.A. 1552 (24); Lopes, M.M.M. 522 (7), 599 (29), 980 (7), 1330 (12), 1445 (29); Lopes, W.P. 731 (43); Lordelo, R.P. 56 (37); Loureiro, D.M. 8 (30); Lua, S. 8 (8); Macedo, G.E.L., 30 (42), 282 (26), 1985 (30); Machado, R.F. 82 (41), 508 (9), 553 (41), 563 (41); Maliarenko, L. s.n. ALCB 67848 (16); Marinho, L.C. 505 (8), Martinelli, G. 6651 (42); Matos, E.N. 935 (2); Mattos, J.R. 12052 (24); Mattos-Silva, L.A. 257 (42), 498, 1320 (15), 2045 (24), 2349 (41), 2580, 2624 (21), 2825 (39), 3508 (24), 3839, 4016 (21), 4480, 4488 (7), 4950 (8); Mayo, S. 1173 (39); Melo, E. 1500 (18), 2026 (41), 2272 (20), 2605 (23), 2753 (41), 2989, 3359, 3394 (35), 3591, 3630 (38), 3781,3890 (32), 3938 (42), 4039 (20), 4385, 4704 (41), 4802 (35), 6387 (41), 6568 (8), 6665 (42), 6847 (18), 7617 (4), 7627, 7654, 8893, 9281 (38), 9381,9405 
(41), 9610 (32), 11688 (8), 11691 (8); Melo, P.A. 192 (26); Menandro, M.S. 85 (33); Mendes, M.S. 473 (8); Menezes, C.M. 270 (18), 363 (2); Miranda, A.M. 4375 (8), 6340 (8); Miranda, E.B. 176 (34), 190, 349 (41), 795 (42), 922, 957 (9); Monteiro, V.M. 54 (41); Mori, S.A. 9261 (29), 9927, 10019 (42), 10118, 10241, 10318 (15), 10326 (30), 10401 (29), 11088 (20), 11776 (42), 11908 (15), 12201 (41), 12357 (19), 12396 (35), 12635 (39), 12757 (21), 12814 (24), 12832 (11), 12861, 13079 (13), 13397 (41), 13626 (35), 14432 (41), 14489 (35); Moura, L.M. 38 (18); Nascimento, A. 252 (41); Nascimento, F.H.F. 170 (8); Neri, J. 58 (12); Neves, M.L.C. 78 (30); Noblick, L.R. 2009 (6), 3477 (8), 3479 (8), 3685 (41), 3692 (32); Nunes, T.S. 282 (41), 346 (35), 808 (2), 1393 (2); Oliveira, C.A.L. 1991 (41); Oliveira, F.C.S. 402 (44); Oliveira, M. 4688 (4); Oliveira, R.P. 364 (32), 946 (19), 948 (8); Orlandi, R. 324 (20); Paixão, J.L. 314 (13), 648 (24), 675 (6), 1099 (23), 1183, 1295 (30), 1580, 1582 (20); Pastore, J.F.B. 2047 (35); Pedra do Cavalo 743 (11), 833 (11), 964 (40), 1089 (10); Perdiz, R.O. 513 (24), 839 (7); Pereira, J.S. s.n. ALCB 19613 (2); Pereira, M.V.L. 185 (11); Pessoa, C. 1 (17), 2 (17), 28 (34), 113 (8), 134 (20); Pessoal do Horto Florestal 555 (27); Pinheiro, R.S. 1883 (30), 2066 (26); Pinto, G.C.P. 101 (41), s.n. ALCB 01907, s.n. JPB 19844, s.n. SP 268931 (26); Pirani, J.R. 463 (24); Plowman, T. 13952 (2); Popovkin, A.V. 219 (30); Prance, G.T. 59610 (17); Prates, A.R. 196, 291 (21); Queiroz, E.P. 1284 (2); Queiroz, L.P. 1012 (6), 1398 (2), 1505 (32), 1837, 2107, 2109 (28), 4324 (40), 4951 (39), 4953 (33), 5058 (35), 5287 (32), 5369 (39), 5464 (38), 5498 (35), 5870 (41), 6372 (21), 6461, 6513 (23), 6559 (41), 7145 (39), 9942 (6), 10606 (41), 10780 (26), 12792 (32), 12821 (12); 13680 (20), 14636, 14643 (41); Rapini, A. 1165 (32), 1204, 1208 (41), 1247 (42), 1262 (8), 1493 (32); Resende, A.V. 39 (18); Ribas, O.S. 242 (24); Ribeiro, T. 110 (18), 321 (33); Ribeiro-Filho, A.A. 183 (23), 220 (39); Rigueira, D. s.n. (ALCB 74634) (18); Rodarte, A.T. 55 (9); Rodrigues, L. 21 (9); Roque, N. 649 (41), 1428 (39), 1867 (8), 1981 (35), 2668 (33), 3248 (17), 3350 (16), 3354 (17), 3602 (8), 3689 (16), 3796 (8), CFCR 14949 (4); Saar, E. 86 (32), 5249 (9), PCD 5316 (41), 5377 (4); Salgado, O.A. 371 (41); Sano, P.T. 14649 (39); Sant'Ana, S.C. 2 , 21 (36), 139 (2), 345 (36), 844 (15), 1032 (37), 1103 (13); Santana, D.L. 579 (40), 647 (39), 724 (34); Santos, B.T.C. 517 (34); Santos, D.L. 56 (39); Santos, E.B. 321 (21), Santos, F.S. 486 (30), 924 (13); Santos, J.M. 13 (17); Santos, R.B. 32 (35); Santos, T.R. PCD 5645 (39), s.n. CEPEC 79631 (39); Santos, T.S. 343 (32), 346 (14), 741 (30), 761 (37), 1068 (21), 1603 (37), 1763 (15), 1946 (13), 2249 (9), 2306 (23), 2670 (15), 2678 (36), 3773 (24), 3896 (36), 4264 (29), 4279 (24), Sartori, A.L.B. 290 (15); Sebastiani, R. 6 (24), 32 (24); Silva, B.M. 121 (41); Silva, F.B.L. 40 (8); Silva, F.H.M. 515 (20); Silva, M.M. 511 (23); Silva, T.R.S. 140 (41), 183 (9); Silva-Junior, A.A. 66 (17); Siqueira-Filho, J.A. 1754 (8); Sobral, M. 7634 (13); Sousa, A.E.A. 58 (35); Sousa, G. 457 (31); Souza, E.R. 85 (8), 97 (35); Souza, V.C. 10710 (24); Souza-Silva, R.F. 189 (32); Stannard, B. PCD 5537 (33); Stapf, M.N.S. 445 (30); Stehmann, J.R. s.n. SP 275842 (24); Stradmann, M.T.S. 1093, 1148 (4); Sucre, D. 8437 (27); Thomas, W.W. 6828 (43), 8995 (24), 9764 (30), 9913 (26), 10013, 10909 (30), 11841 (22), 12199 (24), 12203 (26), 12209 (15), 12368 (3), 12541 (26), 13482 (37), 13943 (6), 14193 (7); Valadão, R.M. 169 (11); Vinha, S.G. 111 (15); Violatti, J.G. 93 (28); Wanderley, P.H.S. 199 (17); Yoshida-Arns s.n. HUEFS 172623 (16); s.c. ALCB: 19495, 20756 (2), 20770 (11), 61218 (18). 